\title{
RECEIVED
}

\author{
AUG 251997 \\ OSTI
}

\section{EVALUATION OF HEPA FILTER SERVICE LIFE}

\author{
Rev. 0
}

July 14, 1997

DISCLAIMER

\begin{abstract}
This report was prepared as an account of work sponsored by an agency of the United States Government. Neither the United States Government nor any agency thereof, nor any of their employees, makes any warranty, express or implied, or assumes any legal liability or responsibility for the accuracy, completeness, or usefulness of any information, apparatus, product, or process disclosed, or represents that its use would not infringe privately owned rights. Reference herein to any specific commercial product, process, or service by trade name, trademark, manufacturer, or otherwise does not necessarily constitute or imply its endorsement, recommendation, or favoring by the United States Government or any agency thereof. The views United States Government or any agency thereor.
\end{abstract}

Prepared By: and opinions of authors expressed herein do not necessarily state or reflect those of the

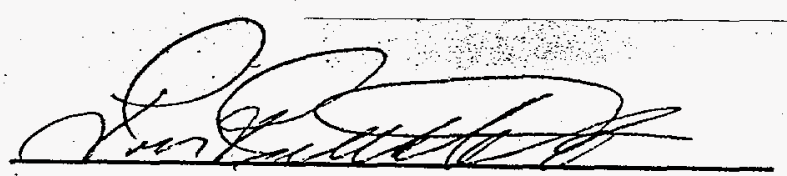

J. K. Fretthold

SSOC Mechanical \& Structural Engineering

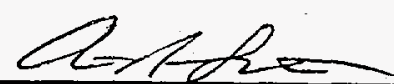

A. R. Stithem

SSOC Operational Nuclear Safety

\section{Approved By:}

R. M. Suyama

SSOC Manager of Engineering \& Construction

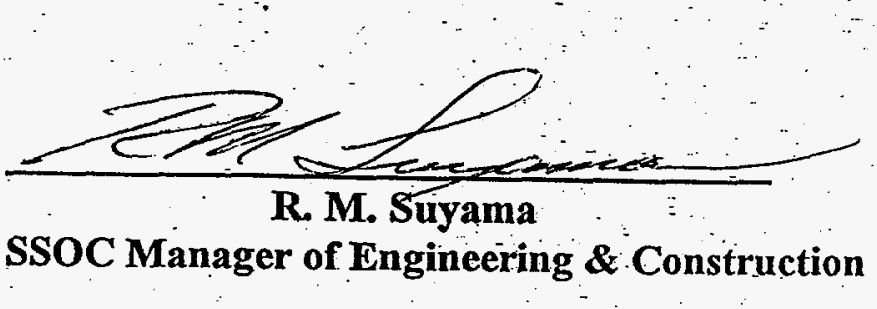




\section{DISCLAMIER}

Portions of this document may be illegible in electronic image products. Images are produced from the best available original document. 
i. EXECUTIVESUMMARX.

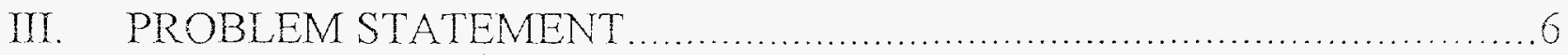

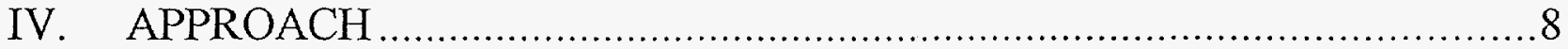

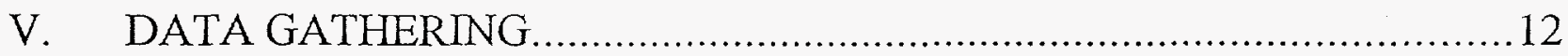

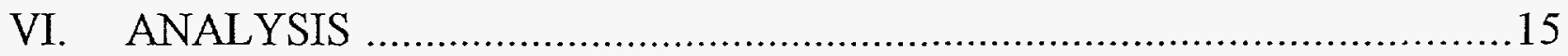

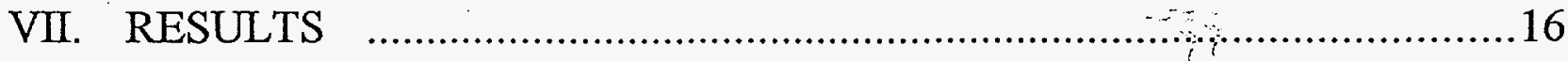

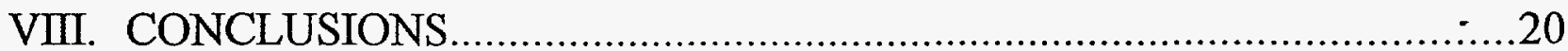

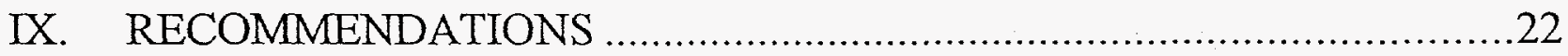

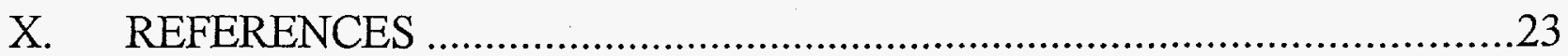

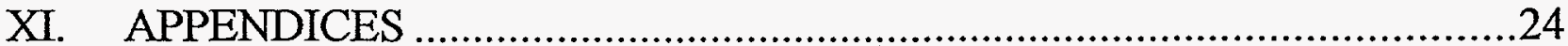


Rocky Flats Envirommental Technology Site (RFETS). has approximately 10,000 High Erriciency Particulate Air (HEPA) Filters installed in a varioty of filter nlenums. These ventilation filtotion plomm systems are used to control the release of airbone particulate contaminates to the enronmen during normal operations and potential accidents. Operational integrity of HEPA filter plenums is essential to

(SARs) and Basis for Interim Operation (BUS) or protection of the public and enviromen.

This report summarizes the results of destructive and non-destructive tests on HEPA filters obtained from a wide variety of ages and service conditions. These tests were performed to determine an acceptable service life criteria for HEPA filters used at Rocky Flats Environmental Technology Site (RFETS). A total of 140 filters of various ages (1972 to 1996) and service history (new, aged unused, used) were tested. For the purpose of this report, filter age from manufacture date/initial test date to the current sample date was used, as opposed to the actual time a filter was installed in an operating system. These tests were performed in three phases:

Phase I Materials property testing of 85 Transuranic (TRU) and Low Level Waste (LLW) filters obtained from waste storage.

Phase II Materials property testing of 55 uncontaminated filters obtained from non-radiological areas.

Phase III Pressure testing of 10 new and used filters

Additionally, the following filter components were inspected: Gasket Material - visual inspection; Adhesive - visual inspection; Separators - visual inspection.

The test results identified additional issues that require further investigation:

- The data does not support the replacement of HEPA filters based solely on age or the development/establishment of age specific service life criteria.

- The wide variation of measured filter parameters between and within manufacturers demonstrates the need for reevaluation of minimum filter specifications.

- A strong QC/QA policy must be adopted and applied at the time of filter manufacture as well as at the 5 year filter requalification per DOE-STD-3020-97 (e.g., inspection by DOE/customer at time of manufacture, destructive tests of components by independent labs at time of manufacture, round-robin test of manufacturer equipment by DOE Controlled Filter Group).

- Significant loss of tensile strength was observed after filters were exposed to water and allowed to dry. Subsequent water exposures resulted in additional loss of tensile strength. Further testing should be pursued to determine at what point a filter will lose physical integrity and is no longer suitable for service. 
or repkacench (oased on anticipated future fachity mission and reiative importance of specific filter stages to safety)

- Alternate deluge system test methodologies should be developed to protect new filters from 


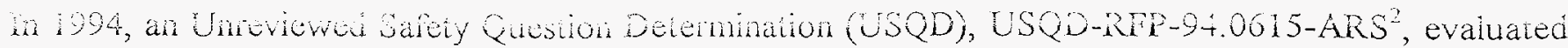
a potential inadequacy of the safety envelone for plutonium building HEPA filter surveillance testing requirements. While conducting this USQD, questions were raised concerning the maximum service life criteria for HEPA filters. Limited data available at that time indicated that HEPA filters could experience

nechanish for tolat hter milure under exteme conditions. Accionen scenarios analyzed in FSARS identified conditions that could potentially result in plugging or damage to HEPA filters, particularly during fires. One such event would be a major fire that requires activation of manual filter plenum deluge systems. It was determined that the sudden application of a water spray to degraded filters could result in catastrophic filter failure, resulting in damage to down stream filters from debris. The issue of age-related filter degradation was identified as an Unreviewed Safety Question (USQ) in USQD-RFP-94.0615-ARS. Compensatory measures identified for the USQ specified testing and analysis of aged HEPA filters in order to determine and implement appropriate service life criteria.

In response to USQD-RFP-94.0615-ARS, RFETS committed to perform a service life study ${ }^{3}$ to determine the effects of aging on HEPA filters. The original study proposal involved obtaining HEPA filter media test samples of various ages from filters used in facilities under a variety of service conditions, and subjecting these samples to tests of tensile strength and water repellency.

The RFETS FSARs credit HEPA filters with entrapment of radioactive particulates released during normal operations and operational accidents occurring within filter protected areas. HEPA filters procured for use in nuclear facilities were manufactured to Mil-Spec requirements for HEPA filters (MIL-F-51068F ${ }^{4}$ and MIL-F-51079D ${ }^{5}$ ), and were qualified to the Mil-Spec requirements. These Mil-Specs established the manufacturing and acceptance criteria for filters used at RFETS when the FSARs were originally written and approved between 1981 and 1988. Under the Mil-Spec requirements, filter components are tested for tensile strength, water repellency, thickness, and temperature resistance. Assembled filters are performance tested for temperature, pressure, and rough handling. Filter components and assemblies must meet specified criteria for each test. Filters that can meet Mil-Spec criteria throughout their service life are assured of performing to ANSI/ASME N-509-1980 ${ }^{6}$ as credited in the FSARs. Therefore, performing a comparison of the data obtained from this evaluation to the MilSpec criteria will provide a guide by which to assess the effects of age and service environment on HEPA filters relative to FSAR credited performance.

This study did not attempt to analyze aged HEPA filters under accident conditions. This study was intended to provide data on observed age-related filter media degradation and water exposure affecting media service life, which could be used to determine service life criteria for HEPA filters used in RFETS facilities. These results may have application at other DOE facilities where HEPA filter system are used for radiological confinement. 
There is little or no guidance on how long hei A fiters can remain in service at DOE facilities. Filters are allowed to remain in service so long as their nressure dron does not incrense bevond established values and the routine in-situ filter tesing results satisfy facility OSR requirements. The current RFETS criteria for replacement of in-service HEPA filters is based on 1) pressure drop, 2) visible filter

testung. These criteria do not identily nters that have degraded structural strengun, and can allow filters to remain in place for practically an unlimited time. Most of the plena at RFETS have filters that have been in service greater than ten years, with some filters in service as long as twenty-two years, that still meet DOP testing and pressure drop requirements. Sufficient data does not currently exist to establish quantitative criteria for maximum HEPA filter service life based on age or service environment degradation. This study evaluates data from HEPA filters that have a variety of ages and service environment exposures to determine if specific service life criteria can be established. RFETS has already established a qualified shelf life for HEPA filters of 10 years, with qualification re-tests to be performed at 5 years $^{7}$.

At Brookhaven National Laboratory, HEPA filter service lives are restricted to 10.5 years for the High Flux Beam Reactor system, and 5.5 years for the Medical Research Reactor and other systems where filter failure could have potentially significant environmental impact. These criteria reflect potential exposure to gamma radiation, which degrades the filter media binder. HEPA filters at RFETS do not experience significant gamma irradiation.

A series of tests performed in 1988 on used uncontaminated HEPA filter media that had been in service from thirteen to twenty years is documented in The Effect of Age on the Structural Integrity of HEPA Filters $^{8}$. New filters were not evaluated in the 1988 tests. This report states:

"In reviewing this summary data we see that $42 \%$ of the filter sheets tested failed either the tensile MD (Machine Direction) or the tensile CD (Cross Direction) tests. Due to the brittleness of the bend area of the pleat, a sample could not be obtained for testing. There is no doubt, however, that this area of the aged HEPA filter media represents the weakest part and it should have even lower tensile strength value. This is indicative of reduced media strength as a result of aging. Seventy-one percent of the filter sheets failed the pressure drop test, which indicates -- as expected -- some loading of the media due to use. All of the filters passed the DOP efficiency tests. This indicates that the DOP test is not indicative of structural changes, which is not surprising to anyone who understands the principles upon which the test is based."

"In most of these (tornado) tests the entire filter pack was blown from the frame. Of the six aged filters tested in the tornado test, five of the filter packs were completely blown out of the frame, and the remaining pack was badly damaged."

"The results from the micro scale/static tests and macro scale/dynamic tests indicate aging effects could be significant. These results are summarized below.

- A $42 \%$ failure of sheet filter paper tensile strength, either MD or CD to the requirements of $M I L-F-51079$. 


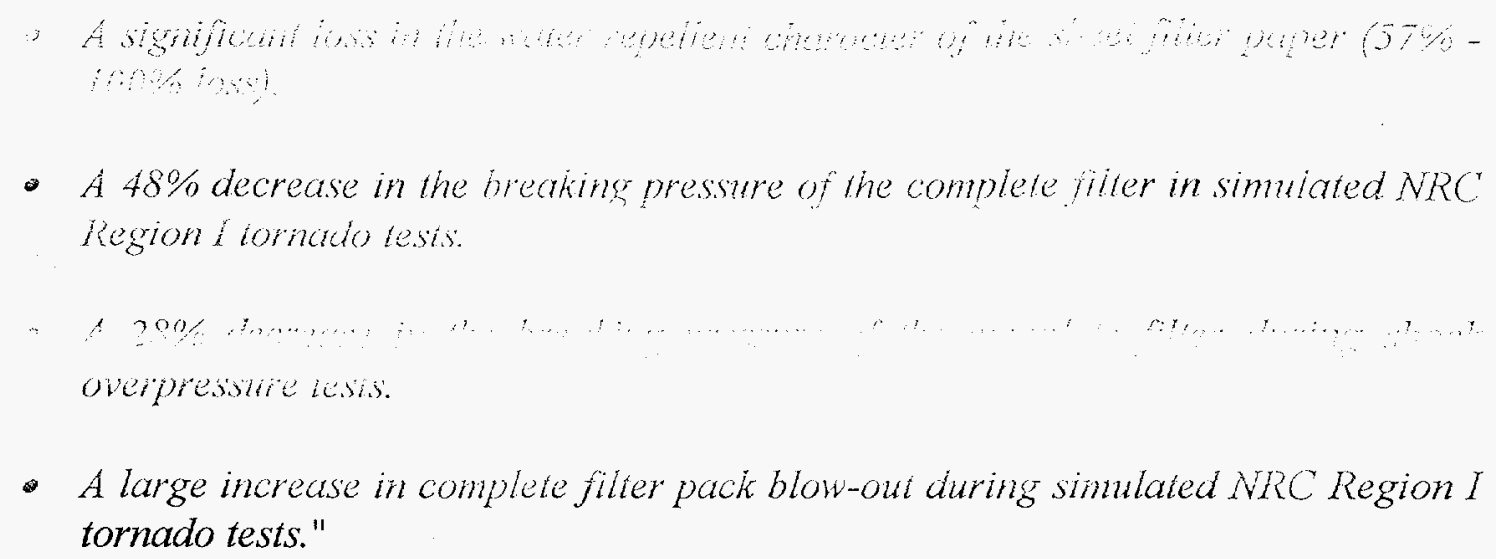

The results of The Effect of Age on the Structural Integrity of HEPA Filters report indicate that HEPA filters in plutonium buildings in service since the 1970s could have experienced significant structural degradation due to aging. Scenarios are possible whereby large pressure differentials could be imposed on aged HEPA filters. Such scenarios include loading or plugging of HEPA filters by combustion products or particles during a fire, or various ventilation system/controller failures which could cause a significant flow increase. Building ventilation exhaust fans are capable of creating sufficiently high differential pressures under these conditions to cause partial or complete structural failure of aged HEPA filter elements. Such failures could potentially cause damage to down stream HEPA stages as a result of flying debris from failed first stage filters. These scenarios formed the basis of the USQ-regarding the probability of HEPA filter malfunction identified in USQD-RFP-94.0615-ARS.

M. W. First in his July 1990 report $^{9}$ on filter systems at RFETS recommended a five year service life interval to preclude the effects of age degradation on the filtration system efficiency. Alternatively, First advised that frequent in-place testing could serve to certify the plenums for continuous service and potentially predict the point of failure. Both solutions would require Air Filter Technicians to enter potentially contaminated areas and therefore are labor intensive and costly. Frequent manual testing and replacement operations also conflict with Site waste minimization and radiological As Low As Reasonable Achievable (ALARA) goals. In his 1996 paper on Aging of HEPA Filters in Service and in Storage ${ }^{10}$, M. W. First again recommended a five year service life interval because of unknown intervals between media manufacture, filter assembly, and storage prior to and after final delivery.

In June, 1997, W. Bergman, et al. ${ }^{11}$, recommended a maximum HEPA filter service life of no more than 5 years, and a total life of no more than 8 years from the date of manufacture. This recommendation was based on peer review of available data (including preliminary test results from this-Service Life Study), and expert opinion from government, industry, and academia.

It is the consensus of the previous reports/papers that conservative age limits need to be assigned. Their recommendations suggest additional data is required. The previous reports/papers recommended 5 to 10 year time frames.

Gilbert, et al. ${ }^{12}$, has estimated the total cost for testing, replacement, and low level waste disposal at $\$ 3,000$ per filter. As previously discussed, RFETS has approximately 10,000 HEPA filters installed in a variety of filter plena. Therefore, any service life criteria could potentially impact worker radiation exposure risk, radioactive waste generation, and costs. 

identified. The number of filters to be tested was based on filter availability and the recommendation of the mombers of thane nome mis

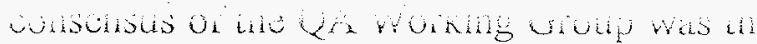
filters. The QA Working Group suggested testing approximately 100 filter samples of various ages The original Test Plan ${ }^{13}$ was divided into the following three phases:

Phase I Materials property testing of 100 TRU and LLW filters obtained from waste storage.

Phase II Materials property testing of 20 uncontaminated filters.

Phase III Pressure testing of 40 uncontaminated filters.

Additionally, the following filter components were to be inspected and/or tested: Gasket Material - visual inspection and compression tests; Adhesive - visual inspection; and Separätös - visual inspection.

Compression tests and life of gaskets have been previously addressed in the Shelf Life Study ${ }^{7}$. The available filter population required a shift in the mix of used and unused test samples from the original Test Plan. Therefore, actual implementation of the Test Plan was performed as follows:

Phase I sampling took place at the RFETS 750 Pad, Tent 5, and in Building 771. Eighty-five filters tested in Phase I were removed from radiological operations areas. The filters ranged in age from six years to twenty-five years. For the purpose of this report, filter age from manufacture date/initial test date to the current sample date was used, as opposed to the actual time a filter was installed in an operating system. Twenty-four filters were sampled in a test plenum located in Building 771. Sixty-one filters were obtained from Building $664 \mathrm{LLW}$ storage. The filters were removed from waste crates in a Ccell in a Permacon structure in Tent 5 . The filters were then transferred into a glovebag connected to the C-cell. Filter media samples were taken and cut to test size in a glovebag. This operation was performed by Rocky Mountain Remediation Services (RMRS) Solid Waste Operations Group and Reengineering \& Operations Services personnel. The samples were then transferred to Building 707, Module J, Glovebox $\mathrm{J}-65$, for Phase I materials property testing. Testing of the samples was performed by Safe Sites Of Colorado (SSOC) Building 559 Radiological Inorganic Laboratory personnel. The filters and media samples were disposed of in compliance with applicable regulatory requirements.

Phase II sampling and testing was conducted in the RFETS Filter Test Facility, Building 442, using filters obtained from DynCorp of Colorado, Inc., Filter Services Department. Fifty-five filters were removed from non-radiological areas and stock storage. The filters ranged in age from one year to twenty-one years. Twenty-four filters had dust loading; the balance (thirty-one) were unused filters. Materials property testing was performed on filter components in Building 442 by SSOC Building 559 Radiological Inorganic Laboratory personnel. These filters were tested in four groups. In Group 1, samples from all fifty-five filters were tested as found. In Group 2, twenty-one samples from the Group 1 filters were wetted (soaked in water for 15 minutes), dried for 24 hours, and tested. In Group 3, 15 samples from Group 2 filters were re-wetted, dried, and tested. In Group 4, 15 new samples from the Group 3 filters were wetted and tested while wet. 


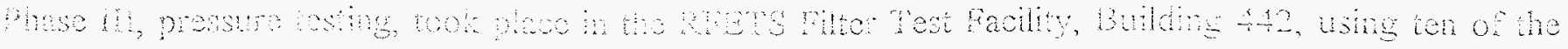
wsang was perioned by SSOC Los Aamos Technica Associates (LATA) Engineering personnel. Each of the fitters was selected, inspected, and inctalled in the Pressure Tect unit Each fiter was slomly loaded with ty ash to buld diferchtial pressure to the point of falure. Filter falures occured between 30 and 42 inches Water Column. It was observed that the amount of fly ash required to reach failure (10

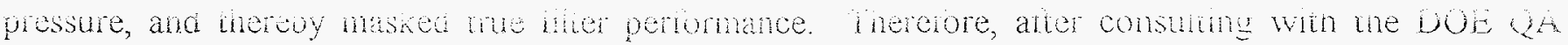
Working Group, it was decided to drop this phase of the Test Plan.

Tests performed on the filter media were drawn from Mil-Spec MIL-F-51079D for HEPA filters manufactured for use in nuclear facilities. The tests were:

- Tensile strength of the media in the machine direction

- Tensile strength of the media in the cross direction

- Thickness

- Water repellency

Specific Mil-Spec MIL-F-51079D filter medium criteria that are used in this evaluation are:

- Average Tensile Strength:

Machine Direction: $\quad 2.5$ Pounds per Inch-Width

Cross Direction: $\quad 2.0$ Pounds per Inch-Width

- Thickness:

Minimum: $\quad 0.015$ Inch (15 Mils)

- Water Repellency:

Single Minimum: 18 Inches Water Column (Water Gauge)

Additionally, Mil Spec MLL-F-51068F requires HEPA filters to withstand a pressure differential of 10.0 inches water column (water gauge). RFETS facility OSRs require HEPA filters to be replaced when pressure differential across a plenum stage reaches 4 inches water column (water gauge). These criteria are also used in this evaluation. 


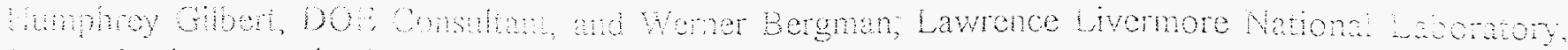

peromed. The following tesis were adied io the test plan, based on fiter fallure mechanisms ooserved in the field:

- Tensile strength of the media in the machine direction across the fold

- Burst pressure on the medatiat

- Burst pressure on the media fold

- Water degradation tests:

Wetted \& dried media tensile strength in the machine direction

Wetted \& dried media tensile strength in the cross direction

Wet tensile strength in the machine direction

Wet tensile strength in the machine direction across the fold

Testing across media folds was selected to evaluate the weakest part of the filter. Burst pressure testing was selected to simulate a pressure pulse in the ventilation system. Testing of media that had been wetted and dried, and wet media, was selected to bound the effects of media exposure to fire suppression system activation and surveillance testing. Filter media test samples were submerged in water for 15 minutes per Mil-Spec MLL-F-51079D, while fire suppression system surveillance tests are typically 10 to 15 seconds. Fire suppression system surveillance tests result in wetting the filter folds on the upstream filter face, which is one of the weakest points on the filter. Additional testing should be performed to evaluate the effects of fire suppression system surveillance tests on filter media.

Figure 1 illustrates typical filter medium layout (machine direction and cross direction), and approximate sample size, location, and orientation. 


\section{Pigums}

Fiter Medum Lavout and Sample Locatione

(Not to Scale)

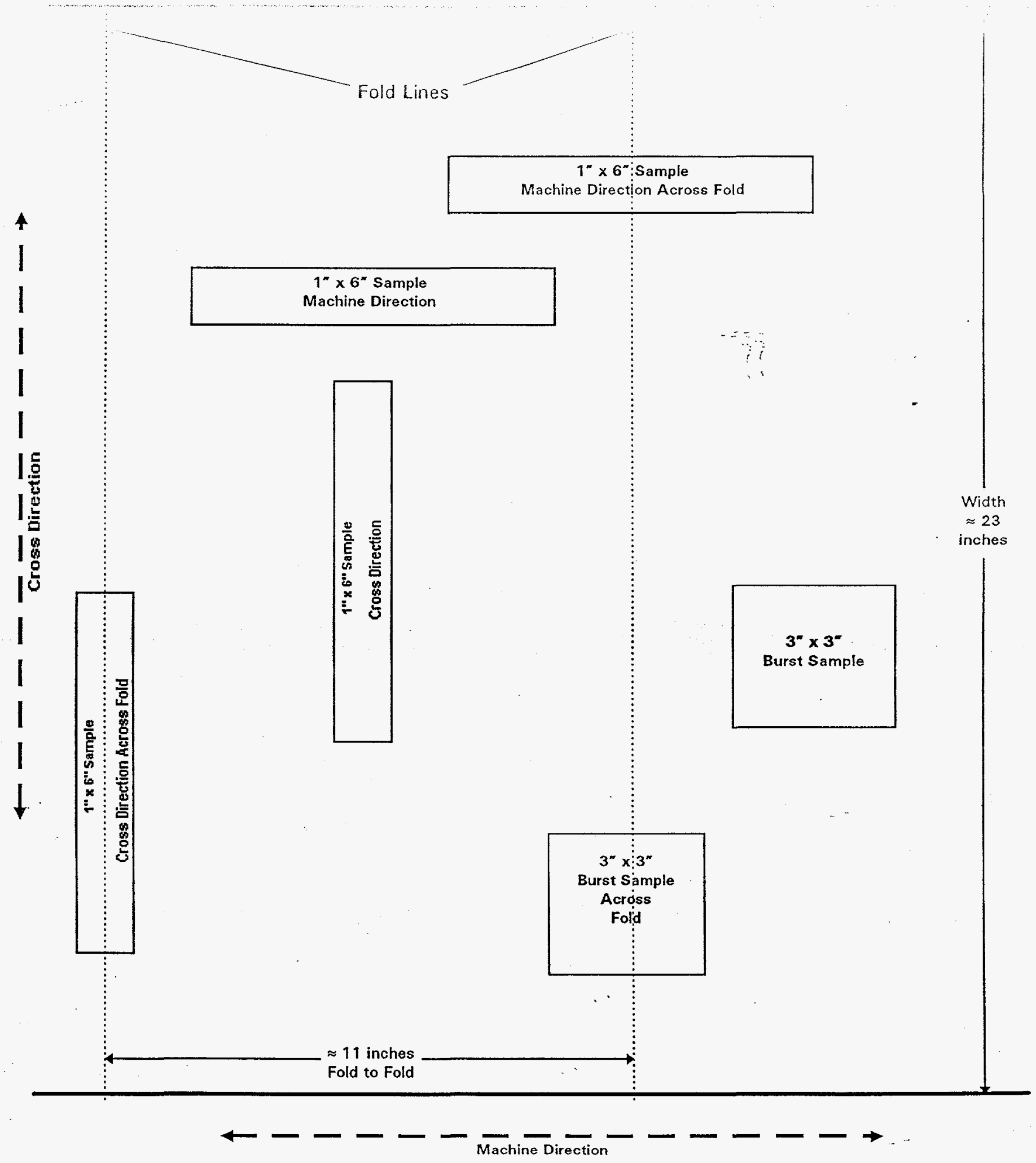


A. The following steps were performed during the Phase! tests on sixty-one used Low Level Waste (LLW) filters.

2. Move waste crates to 750 Pad, Tent 5.

3. Remove filters in Permacon/C-cell

4. Move filters into glovebag.

5. Record filter information.

a) Serial number

b) Manufacturer

c) Date of testing by Manufacturer/Filter Test Facility

d) Service Life History (date of installation if available, service environment, plenum, stage.)

6. Remove samples for materials property testing.

7. Cut samples to test size in glovebag.

8. Transfer test samples to Building 707, Module J, Glovebox -65 for testing.

B. The following steps were performed on twenty-four used filters obtained from a test plenum in Building 771 .

1. Record filter information.

a) Serial number

b) Manufacturer

c) Date of testing by Manufacturer/Filter Test Facility

d) Service Life History (date of installation if available, service environment, plenum, stage.)

2. Remove samples for materials property testing.

3. Cut samples to test size in the Radiological Buffer Area (RBA) in Building 771.

4. Perform water repellency tests on the twenty-four samples in the Building 771 RBA.

4. Transfer test samples to Building 707, Module J, Glovebox J-65 for testing.

C. The following steps were performed in Building 707, Glovebox J-65, on sixty-one LLW filters:

1. Perform the following tests:

a) Tensile strength on media-machine direction

b) Tensile strength on media-machine direction on fold

c) Tensile strength on media-cross direction

d) Tensile strength on media-cross direction on fold

e) Burst pressure

f) Burst pressure on fold

g) Thickness of media

2. Results reported to engineering for analysis. 
A. The following steps were performed during Phase 1 tests conducted on samples from a total of fifty-five new and used filters in the RFETS Filter Test Facility:

1. Move filters to be sampled to Filter Test Faciity (Building 442)

2. Record filter information.

b) Manufacturer

c) Date of testing by Manufacturer/Filter Test Facility

d) Service Life History (date of installation, service environment, plenum, stage.)

3. Remove samples for materials property testing (Group 1).

4. Perform the following tests:

a) Tensile strength on media - machine direction

b) Tensile strength on media - machine direction on fold

c) Tensile strength on media - cross direction

d) Tensile strength on media - cross direction on fold

e) Water repellency

f) Burst pressure

g) Burst pressure on fold

h) Thickness of media

5. Results reported to engineering for analysis.

B. The following steps were performed on twenty-one filter samples from item A above (Group 2):

1. Remove and cut test samples for $\mathrm{H} 2 \mathrm{O}$ treatment/materials property testing.

2. Submerge samples in water for thirty minutes; allow samples to dry for twenty-four to forty-eight hours.

3. Perform the following tests:

a) Tensile strength on media - machine direction.

b) Tensile strength on media - cross direction.

c) Burst pressure.

4. Results reported to engineering for analysis.

C. The following steps were performed on three of the twenty-one samples from item B above (Group 3):

1. Rewet samples for fifteen minutes; allow samples to dry for twenty-four hours.

2. Perform the following tests:

a) Tensile strength on media - machine direction.

b) Tensile strength on media - cross direction.

c) Burst pressure

3. Results reported to engineering for analysis.

D. The following steps were performed on fifteen of the twenty-one samples from item B above (Group 4):

1. Wet samples for fifteen minutes; test while samples are wet, within two minutes.

2. Perform the following tests:

a) Tensile strength on media - machine direction.

b) Tensile strength on media - machine direction on fold.

3. Results reported to engineering for analysis. 
A. The following steps were performed on ten new and used hiters in the RFETS Filter Test Facility:

1. Record filter information.

a) Serial number

b) Manufacturer

d) Sorvice lite tistory (ate onstataton it avataole, service environmen, ponm, stage.)

2. Inspect filters

a) Gasket - visual (note any defects)

b) Separators - visual (note any defects)

c) Sealant - visual (note any defects)

3. Install in Pressure Test Unit and test

a) Run at rated flow (1000 cfm), check differential pressure

b) Increase cfm and inject fly ash to the point of failure

4. Results reported to engineering for analysis. 
RiETS Mechanical \& Structural Engineering, RFETS Operational Nuclear Safety, and consultants from DOE and Tawence Livermore National Laboratory performed the analysis of data obtained from the tests. The test data was sorted into five groups, based on relevancy to operational failure and service life analysis: Water Repellency; Water Degradation, Tensile Strength - Machine Direction; Burst Pressure.

Water Repellency:

Mil-Spec MLL-F-51079D requires each filter to withstand a minimum of 18 inches water column (water gauge). Loss of water repellency renders the filter media susceptible to water penetration which weakens the media and results in a loss of tensile strength and resistance to burst pressure.

Water Degradation: Exposure of filter media to water will potentially degrade the media tensile strength and resistance to burst pressure, especially with inadequate water repellency characteristics. Media samples were wetted and dried to simulate exposure to water during plenum deluge system surveillance testing, and then tested for tensile strength in the Machine Direction. Subsets of filters were tested after multiple water exposures, and while wet.

Tensile Strength: $\quad$ Mil-Spec MIL-F-51079D requires a minimum tensile strength of 2.5 pounds per inch width in the Machine Direction. Tensile strength in the Machine Direction was evaluated because this orientation across the filter fold represents the weakest configuration. Separation at a filter fold is one of the more common failure modes observed in the field.

Burst Pressure: $\quad$ MIL-F-51068F requires HEPA filters to withstand a pressure differential of 10.0 inches water column (water gauge). RFETS facility OSRs require HEPA filters to be replaced when pressure differential across a plenum stage reaches 4 inches water column (water gauge). Burst pressure testing was performed to simulate stress on the filter media similar to a high differential pressure transient.

Manufacturer Variances:

Manufacturers "A", "B", and "C" account for more than $80 \%$ of all HEPA filters installed at RFETS. The remaining $20 \%$ is distributed among four other manufacturers. The test data clearly demonstrates wide variability of all measured filter parameters between and within each manufacturere, even in filters manufactured at approximately the same time. This wide range of variation in measured filter parameters appears to be more significant than the effects of agerelated degradation. 
Test data is provided in spreadsheet form in Appendix 1. Specific test results for Water Repellency.

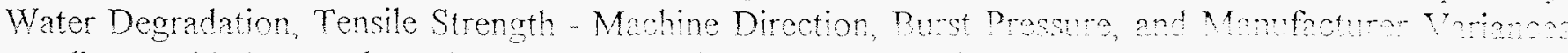
are discussed below, and graphs are presented in Appendices 2 through 6. Least square fit (Linear) lines are provided to show data trends, although these trends are potentially affected by individual data points.

Water Repellency Tests (Appendix 2)

1. Testing of Unused Filters (Graph 2-1): Twenty-nine (29) filters of various ages from various manufacturers were tested. Four (4) samples (14\%) did not meet the minimum required standard of 20 inches water column.

2. Testing of Dust Loaded Filters (Graph 2-2): Twenty-four (24) filters of various ages from various manufacturers were tested. Twenty (20) samples (83\%) did not meet the minimum required standard.

3. Testing of Used Clean Filters (Graph 2-3): Twenty-four (24) filters of various ages from various manufacturers were tested. Four (4) samples (17\%) did not meet the minimum required standard.

\section{Water Degradation Tests (Appendix 3)}

1. Testing of Unused and Dust Loaded Filters - Tensile Strength (Graph 3-1): Three (3) unused filters and three (3) used filters of various ages from various manufacturers were tested by wetting (soaking in water for 15 minutes), allowing them to dry for 24 hours, and then measuring tensile strength in the Machine Direction. The three (3) unused filter samples showed a reduction in tensile strength from $30 \%$ to $60 \%$.

The three (3) dust loaded filters were tested twice. After the first test, the dust loaded samples showed a reduction in tensile strength in the Machine Direction from $20 \%$ to $60 \%$. After the second test, two (2) of the samples showed a further reduction in tensile strength between $5 \%$ and $10 \%$.

2. Testing of Dust Loaded Filters - Tensile Strength (Graph 3-2): Fifteen (15) filters of various ages from various manufacturers were tested by wetting, drying, and then measuring tensile strength in the Machine Direction. Eleven (11) samples (73\%) showed a reduction in tensile strength, and five (5) of these samples $(33 \%)$ did not meet the minimum required standard. The reduction in strength ranged from $5 \%$ to $60 \%$.

3. Testing of Dust Loaded Filters Wet Tensile Strength (Graph 3-3): Fifteen (15) filters of various ages were tested for tensile strength in the Machine Direction while wet. All fifteen (15) samples (100\%) exceeded the minimum wet tensile strength specification of $1.0 \mathrm{lb} /$ in-width.

Samples from these fifteen (15) filters were also wetted and tested for tensile strength in the Machine Direction across the fold while wet. Note that the Machine Direction across the fold is the weakest configuration and that the fold is the most common failure point on the filter. Fourteen (14) samples $(93 \%)$ were less than $1.0 \mathrm{lb} / \mathrm{in}$-width while wet. 
i. Iesting of Unused filters (Graph 4-i) Twenty-nine (29) iilters of various ages from various manufacturers were tested. Twenty-four (24) samnles (83\%) tested above the Mil-Snec minimum specitication of $2.5 \mathrm{jb} / \mathrm{in}$-width on the llat. When tested across the fold, eighteen ( 18 , of the samples $(62 \%)$ failed to meet the minimum specification

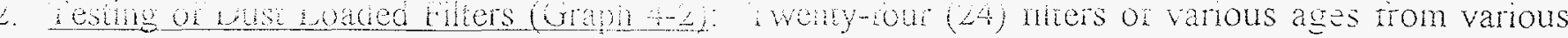
manufacturers were tested. Two (2) samples ( $8 \%$ ) did not meet the minimum specification of 2.5 1b/in-width on the flat. When tested across the fold, twenty-three (23) samples $(96 \%)$ failed to meet the minimum specification.

3. Testing of Used Clean Filters (Graph 4-3): Twenty-four (24) filters of various ages from various manufacturers were tested. Two (2) samples $(8 \%)$ did not meet the minimum specification of 2.5 $\mathrm{lb} / \mathrm{in}$-width on the flat. When tested across the fold, eighteen (18) samples (75\%) failed to meet the minimum specification.

4. Testing of Used LLW Filters (Graph 4-4): Sixty-one (61) filters of various ages from various manufacturers were tested. Twelve (12) samples (20\%) did not meet the minimum specification of $2.5 \mathrm{lb} / \mathrm{in}$-width on the flat. When tested across the fold, sixty (60) samples (98\%) failed to meet the minimum specification. The highest reading was $3.8 \mathrm{lb} /$ in-width, and the lowest reading was $0.1 \mathrm{lb} / \mathrm{in}-$ width. The average was $0.3 \mathrm{lb} /$ in-width.

\section{Burst Pressure Tests (Appendix 5)}

1. Testing of Unused Filters (Graph 5-1): Twenty-nine (29) filters of various ages from various manufacturers were tested. All twenty-nine (29) samples (100\%) tested above the 10 inches water column Mil-Spec requirement, across the flat and across the fold.

2. Testing of Dust Loaded Filters (Graph 5-2): Twenty-four (24) filters of various ages from various manufacturers were tested across the fold and flat. All twenty-four (24) samples $(100 \%)$ tested above the 10 inches water column Mil-Spec requirement across the flat. One (1) sample (4\%), the oldest, did not meet 10 inches water column across the fold. All samples did exceed the OSR differential pressure requirement of 4 inches water column across the fold and flat.

3. Testing of Water Exposed Dust Loaded Filters (Graph 5-3): Fifteen (15) filters of various ages from various manufacturers were tested. All fifteen (15) samples (100\%) tested above the 10 inches water column across the flat prior to water exposure. One (1) sample (7\%) did not meet 10 inches water column across the flat after water exposure and drying.

4. Testing of Used Clean Filters (Graph 5-4): Twenty-four (24) filters of various ages from various manufacturers were tested. All twenty-four (24) samples (100\%) tested above 10 inches water column across the flat and the fold. 
Toming of Jed Li, Filters (Oraph 5-5): Sixu-one

manufacturers were tested. All sixty-one (61) samples (100\%) tested above the 10 inches water column across the flat. Three (3) samples (5\%) failed to meet the 10 inches water column across the foid, but did exceed the OSR differential pressure requirement of 4 inches water column. These three samples were all less than nine years old

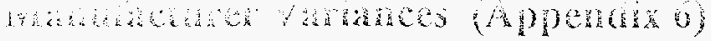

1. Unused Filters, Tensile Strength (Graph 6-1): Nine (9) filters from Manufacturer "A" and six (6) filters from Manufacturer "B" are shown. Manufacturer "A" shows some correlation between loss of tensile strength and age, and also shows $25 \%$ to $30 \%$ variance in filters of the same age. Manufacturer " $\mathrm{B}$ " shows no correlation between age and tensile strength, and shows $200 \%$ to $300 \%$ variance between filters of approximately the same age.

2. Unused Filters, Burst Pressure (Graph 6-2): Nine (9) filters from Manufacturer " $A$ " and six (6) filters from Manufacturer "B" are shown. Results are similar to Tensile Strength (Graph 6-1). Manufacturer " $\mathrm{A}$ " shows some correlation between burst pressure and age, and also shows $20 \%$ to $40 \%$ variance in filters of the same age. Manufacturer " $\mathrm{B}$ " shows no correlation between age and burst pressure, and shows $200 \%$ to $300 \%$ variance between filters of approximately the same age.

3. Used Clean Filters, Tensile Strength (Graph 6-3): Three (3) filters from Manufacturer "A", nine (9) filters from Manufacturer "B", and one (1) filter from Manufacturer " $C$ " are shown. Manufacturer " $A$ " shows no correlation between tensile strength and age, and little variance. Manufacturer " $\mathrm{B}$ " shows no correlation between age and tensile strength, and significant variance (up to $400 \%$ ) between filters manufactured within the same year. No conclusions can be drawn from the single filter sample from Manufacturer "C".

4. Used Clean Filters, Burst Pressure (Graph 6-4): Three (3) filters from Manufacturer “ $A$ ", nine (9) filters from Manufacturer " $\mathrm{B}$ ", and one (1) filter from Manufacturer " $\mathrm{C}$ " are shown. Manufacturer "A" shows no correlation between burst pressure and age, and some variance (35\%) between two (2) filters of the same age. Manufacturer " $B$ " shows no correlation between age and burst pressure, and significant variance (up to $700 \%$ ) between filters manufactured within the same year. No conclusions can be drawn from the single filter sample from Manufacturer "C".

5. LLW Filters, Tensile Strength (Graph 6-5): Nine (9) filters from Manufacturer "A", twenty-seven (27) filters from Manufacturer " $\mathrm{B}$ ", and nine (9) filters from Manufacturer " $\mathrm{C}$ " are shown. There is no discernable correlation between age and tensile strength for the three manufacturers, and all manufacturers show between $100 \%$ and $700 \%$ variance between filters of approximately the same age.

6. LLW Filters, Burst Pressure (Graph 6-6): Nine (9) filters from Manufacturer "A", twenty-seven (27) filters from Manufacturer " $B$ ", and nine (9) filters from Manufacturer " $C$ " are shown. There is no discernable correlation between age and burst pressure for any of the three manufacturers, and all manufacturers show between $100 \%$ and $300 \%$ variance between filters of approximately the same age. 


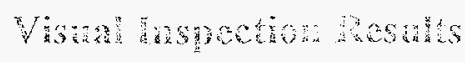

Gaskets

Separators
No deficiencies noted

No deficiencies noted

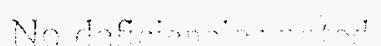




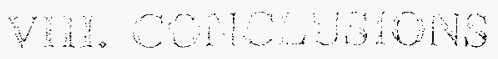

Generat Concinsons:

- The wide variability of measured filter parameters between and within manufacturers generally conceals the effects of age-related degradation. This demonstrates the need for tightening of

testhe mion 6 placing filters in service.

- Folds with the Machine Direction are the weakest points of the filters.

- A dust loaded filter is weaker than a clean filter.

- A filter exposed to water can be weakened, even after it dries. The test data shows a reduction in tensile strength of up to $60 \%$.

- Dust loaded filters exposed to water are the weakest.

- A filter repeatedly exposed to water can continue to be reduced in tehsile strength.

- Measured filter parameters (water repellency, tensile strength, burst pressure) vary significantly by batch within the same manufacturer. For example, measured tensile strength - machine direction (Mil-Spec criteria $-2.5 \mathrm{lb} /$ inch-width) on a set of five filters from the same manufacturer yielded the following results, expressed as Year Manufactured vs. lb/inch-width:

1973: $3.7 \quad 1981: 7.1 \quad 1983: 2.1 \quad 1986: 4.4 \quad 1991: 2.2$

\section{Water Repellency Conclusions:}

- Exposure of first stage filters to water during OSR required plenum deluge system surveillance tests can reduce the tensile strength of filters to less than Mil-Spec levels.

\section{Water Degradation Conclusions:}

- Significant loss of tensile strength was observed after filters were exposed to water and allowed to dry. Further water exposures resulted in additional loss of tensile strength on clean filters. 
Tensile Strength - Machine Direction Conchusions:

- The data in this evaluation clearly demonstrates that the filter pleats (folds) are the weakest pait of the filter. Tests of filter media across the folds show significant deficiencies with respect to the current Mil-Spec criteria and OSR requirements. Between $62 \%$ and $98 \%$ of all tests across the fold failed the Mil-Spec minimum tensile strength criteria $(2.5 \mathrm{lb} / \mathrm{in}$-width).

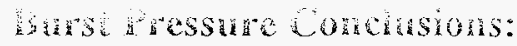

- Unused, dust loaded - water exposed, and used clean filters showed a clear trend of degraded burst pressures across the flat associated with age.

- Burst pressure across the flats was consistently $200 \%$ to $300 \%$ higher than burst pressure across the folds.

\section{Age Related Degradation Conclusions:}

- It is the consensus of previous reports/papers, 10,11 that conservative age limits need to be assigned. Their recommendations suggest additional data is required. The previous reports/papers recommended 5 to 10 year time frames until additional test data was available. The data from this report, which is based on 140 filters, does not support replacement based solely on age.

- Few clear trends directly related to age induced media degradation have emerged from this data. Other factors (e.g., initial quality, exposure to water, dust loading, fold weakness) appear to have an overriding influence on filter service life. 
- The data coes not support the replacement of HEPA filters based solely on age or the development/establishment of age specific service life criteria.

- The wide variation of measured filter parameters between and within manufacturers demonstrates

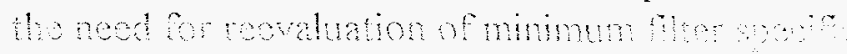

- A strong QC/QA policy must be adopted and applied at the time of filter manufacture as well as at the 5 year qualification (e.g., inspection by DOE/customer at time of manufacture, destructive tests of components by independent labs at time of manufacture, round-robin test of manufacturer equipment by DOE Controlled Filter Group).

- In light of other evaluations $8,9,10,11,12$ and the reduction in operational and service environment challenges to RFETS HEPA filters, current in-situ DOP testing and visual inspections at 18 month intervals should continue.

- Significant loss of tensile strength was observed after filters were exposed to water and allowed to dry. Subsequent water exposures resulted in additional loss of tensile strength. Further testing should be pursued to determine at what point a filter will lose significant physical integrity and is no longer suitable for service.

- Filters routinely exposed to water from deluge system surveillance tests should be given priority for replacement (based on anticipated future facility mission and relative importance of specific filter stages to safety). The plenum first stage filters have been exposed to water during annual or semi-annual surveillance tests since 1987. The face (first $1 / 2$ inch of the filter media, upstream side) has been repeatedly wetted. This is the fold portion of the filter media, and is the most vulnerable to failure as demonstrated in this Service Life Study.

- Alternate deluge system test methodologies should be developed to protect filters from waterexposure degradation resulting from surveillance tests. 


\section{REFERENCES}

1. DOE Standard DOE-STD-3020-97, Specification for HEPA Filters Used by DOE Contractors January 1997

2. USQD-RFP-94.0615-ARS, Non-Resumption Plutonium Building HEPA Filter Plenum Testing Ai Rocky Flats Plant, Zones I, IA, And II, Revision 1, August 25, 1994

3. Rocky Flats Environmental Technology Site (Site) HEPA Filter Implementation Plan, Revision 0, November 1994

4. Military Specification MIL-F-51068F, Filters, Particulate (High-Efficiency Fire Resistant), June 20,1986

5. Military Specification MIL-F-51079D, Filter Medium, Fire-Resistant, High-Efficiency, March 14, 1985

6. ANSI/ASME N-509-1980, Nuclear Power Plant Air Cleaning Units and Components

7. RFETS Interoffice Correspondence, R.E. Fray to W.J. McAndrew, Shelf Life of High Efficiency Particulate Air (HEPA) Filters, November 30, 1993

8. The Effect of Age on the Structural Integrity of HEPA Filters, James S. Johnson et al., 20th DOE/NRC Nuclear Air Cleaning Conference, 1988

9. Report on Filter Systems at Rocky Flats Plant, (Draft), M. W. First, July 16, 1990

10. Aging of HEPA Filters in Service and in Storage, Journal of the American Biological Safety Association, M.W. First, 1996

11. Recommendation for HEPA Filter In Service and In Storage Lifetime, (Draft), W. Bergman, et al., June 20, 1997

12. Preliminary Studies to Determine the Shelf Life of HEPA Filters, Proceedings of the $23^{\text {rd }}$ DOE/NRC Nuclear Air Cleaning Conference, H. Gilbert, et al., July 25, 1994, CON-940738, NTIS

13. HEPA Filter Service Life Test Plan, J. K. Fretthold, October, 1996 
XI. Appendices

1. Spreadsheet Data

2. Water Repellency Tests

3. Water Degradation Tests

4. Tensile Strength Tests

5. Burst Pressure Tests

6. Manufacturer Variances

7. Photographs

8. Test Equipment Specifications 
APPENDIX 1

Spreadsheet Data 
Appendix 1

Unused Filter Data

\begin{tabular}{|c|c|c|c|c|c|c|c|c|c|c|}
\hline Date & Age & Thickness & Burst & $\begin{array}{c}\text { Burst Across } \\
\text { Fold } \\
\end{array}$ & $\begin{array}{l}\text { Tensile - } \\
\text { Machine } \\
\text { Direction } \\
\end{array}$ & $\begin{array}{c}\text { Tensile - } \\
\text { Machine } \\
\text { Direction } \\
\text { Across Fold } \\
\end{array}$ & $\begin{array}{c}\text { Tensile - Cross } \\
\text { Direction }\end{array}$ & $\begin{array}{c}\text { Tensile - Cross } \\
\text { Direction } \\
\text { Across Fold } \\
\end{array}$ & Water Repellency & Sample APO \\
\hline Manufactured & (Years) & (Mils) & (PSI) & (PSI) & (lb/in.-width) & (Ib/in.-width) & (lb/in.-width) & (lb/in.-width) & (Inches Water) & NO. 9791464 \\
\hline Jan-76 & 21 & 17.7 & 1.2 & 0.4 & 1.9 & 0.8 & 1.9 & 1.6 & 36.8 & 53 \\
\hline Dec-77 & 20 & 17.2 & 1.2 & 0.4 & 2.9 & 0.9 & 2.6 & 2.2 & 30.0 & 52 \\
\hline Aug-80 & 17 & 17.7 & 4.7 & 1.2 & 3.6 & 2.0 & 3.4 & 2.5 & 42.0 & 6 \\
\hline Mar-82 & 15 & 17.8 & 3.7 & 2.1 & 3.7 & 3.3 & 2.6 & 2.7 & 24.8 & 16 \\
\hline Aug-82 & 15 & 20.7 & 2.5 & 1.3 & 2.9 & 1.7 & 2.3 & 1.8 & 17.1 & 1 \\
\hline Aug-82 & 15 & 19.8 & 3.6 & 1.7 & 3.6 & 2.4 & 2.9 & 2.8 & 36.3 & 2 \\
\hline Aug-82 & 15 & 18.9 & 2.4 & 1.4 & 3.3 & 2.1 & 2.5 & 2.8 & 42.0 & 10 \\
\hline Aug-82 & 15 & 19.8 & 2.6 & 1.2 & 3.1 & 2.0 & 2.1 & 2.1 & 30.8 & 48 \\
\hline Aug-82 & 15 & 19.6 & 2.6 & 1.6 & 3.2 & 2.3 & 2.6 & 2.6 & 35.0 & 47 \\
\hline Feb-83 & 14 & 17.4 & 4.2 & 1.6 & 2.5 & 2.2 & 2.6 & 2.5 & 42.0 & 49 \\
\hline Apr-83 & 14 & 17.4 & 4.6 & 2.8 & 3.8 & 3.2 & 3.0 & 2.5 & 26.0 & 24 \\
\hline Aug-83 & 14 & 17.9 & 2.1 & 1.0 & 3.0 & 1.8 & 1.8 & 1.7 & 42.0 & 46 \\
\hline Jun-86 & 11 & 18.8 & 5.7 & 1.5 & 4.9 & 2.3 & 3.0 & 2.7 & 42.0 & 45 \\
\hline Jun-87 & 10 & 20.4 & 3.5 & 1.5 & 4.4 & 2.2 & 3.2 & 2.1 & 23.9 & 4 \\
\hline Jun-88 & 9 & 17.4 & 7.1 & 2.2 & 4.8 & 2.1 & 3.5 & 3.0 & 41.8 & 14 \\
\hline Aug-88 & 9 & 18.0 & 3.9 & 1.4 & 3.5 & 1.2 & 2.6 & 2.2 & 42.0 & 54 \\
\hline Aug-88 & 9 & 17.9 & 6.7 & 1.8 & 3.6 & 2.3 & 2.7 & 2.7 & 39.8 & 51 \\
\hline Feb-89 & 8 & 20.8 & 2.1 & 0.8 & 3.1 & 1.5 & 2.1 & 2.2 & 42.0 & 44 \\
\hline Feb-89 & 8. & 16.1 & 1.9 & 0.5 & 2.5 & 0.7 & 1.9 & 1.9 & 42.0 & 43 \\
\hline Feb-89 & 8 & 19.2 & 1.3 & 0.6 & 2.3 & 1.0 & 1.8 & 1.1 & 20.5 & 23 \\
\hline Apr-90 & 7 & 15.9 & 0.8 & 0.4 & 1.5 & 0.9 & 1.6 & 1.2 & 29.0 & 36 \\
\hline Dec-92 & 5 & 18.6 & 6.1 & 1.2 & 4.8 & 2.1 & 3.2 & 2.7 & 42.0 & 50 \\
\hline Feb-94 & 3 & 17.1 & 3.1 & 1.6 & 3.9 & 2.8 & 3.0 & 2.8 & 36.0 & 55 \\
\hline Mar-94 & 3 & 16.7 & 5.9 & 1.3 & 4.9 & 3.3 & 2.7 & 2.3 & 42.0 & 37 \\
\hline May-94 & 3 & 22.1 & 2.9 & 1.2 & 4.9 & 2.4 & 3.3 & 2.8 & 37.0 & 19 \\
\hline Sep-95 & 2 & 15.7 & 4.4 & 0.9 & 3.3 & 2.6 & 2.9 & 2.5 & 15.4 & 17 \\
\hline Dec-95 & 2 & 15.0 & 4.5 & 1.5 & 5.0 & 2.8 & 2.7 & 2.2 & 27.1 & 8 \\
\hline $\operatorname{Jan}-96$ & 1 & 16.6 & 6.1 & 1.2 & 4.9 & 1.9 & 4.9 & 2.1 & 15.5 & 20 \\
\hline Jul-96 & 1 & 13.4 & 3.2 & 0.5 & 3.4 & 1.8 & 2.0 & 1.7 & 13.0 & 18 \\
\hline
\end{tabular}


Appendix 1

Dust Loaded Filter Data

\begin{tabular}{|c|c|c|c|c|c|c|c|c|c|c|}
\hline Date & Age & Thickness & Burst & $\begin{array}{l}\text { Burst Across } \\
\text { Fold }\end{array}$ & $\begin{array}{l}\text { Tensile - } \\
\text { Machine } \\
\text { Direction }\end{array}$ & $\begin{array}{c}\text { Tensile - Machine } \\
\text { Direction Across } \\
\text { Fold }\end{array}$ & $\begin{array}{c}\text { Tensile - Cross } \\
\text { Direction }\end{array}$ & $\begin{array}{c}\text { Tensile - Cross } \\
\text { Direction Across } \\
\text { Fold }\end{array}$ & Water Repellency & Sample APO \\
\hline Manufactured & (Years) & (Mils) & (PSI) & (PSI) & (lb/in.-width) & (lb/in.-width) & (ib/in.-width) & (lb/in.-width) & (Inches Water) & NO. 9791464 \\
\hline Sep-83 & 14 & 20.4 & 1.8 & 0.3 & 3.1 & 1.1 & 2.4 & 1.7 & 12.3 & 9 \\
\hline Sep-83 & 14 & 22.2 & 2.1 & 0.7 & 3.5 & 1.2 & 2.8 & 1.9 & 12.5 & 12 \\
\hline Nov -84 & 13 & 19.0 & 2.0 & 0.4 & 4.7 & 1.1 & 3.4 & 2.3 & 11.8 & 11 \\
\hline Sep-86 & 11 & 19.0 & 2.5 & 0.6 & 3.1 & 1.1 & 2.4 & 1.8 & 20.7 & 41 \\
\hline Sep-86 & 11 & & 2.7 & 1.3 & 2.2 & 0.8 & 1.7 & 1.6 & & 42 \\
\hline Oct-86 & 11 & 20.1 & 2.9 & 1.0 & 4.2 & 1.7 & 3.6 & 3.4 & 14.0 & 13 \\
\hline Oct-86 & 11 & 19.6 & 1.6 & 0.7 & 2.6 & 1.1 & 3.0 & 2.1 & 16.1 & 15 \\
\hline Oct- 86 & 11 & 18.6 & 2.8 & 1.2 & 4.6 & 2.3 & 3.7 & 2.3 & 19.6 & 27 \\
\hline Oct- 86 & 11 & 20.3 & 3.6 & 1.0 & 5.1 & 2.9 & 3.9 & 3.2 & 31.8 & 28 \\
\hline Jun-87 & 10 & 19.8 & 7.1 & 2.0 & 4.3 & 1.4 & 3.0 & 2.3 & 15.5 & 26 \\
\hline Dec-89 & 8 & 17.2 & 1.4 & 0.6 & 2.4 & 1.0 & 2.2 & 1.7 & 15.0 & 39 \\
\hline Dec-89 & 8 & 19.6 & 2.3 & 0.4 & 3.6 & 0.9 & 2.6 & 2.3 & 13.6 & 34 \\
\hline Dec-89 & 8 & 19.6 & 2.4 & 0.9 & 2.6 & 1.6 & 2.9 & 2.2 & 7.8 & 25 \\
\hline $\operatorname{Jan}-90$ & 7 & 18.5 & 2.5 & 1.0 & 3.9 & 1.4 & 3.0 & 2.4 & 11.5 & 21 \\
\hline Jan-90 & 7 & 20.3 & 2.1 & 0.6 & 3.8 & 1.2 & 2.7 & 2.3 & 13.0 & 22 \\
\hline $\operatorname{Jan}-90$ & 7 & 20.8 & 2.1 & 0.6 & 3.3 & 1.1 & 2.3 & 1.9 & 16.6 & 29 \\
\hline Jan-90 & 7 & 19.5 & 2.2 & 1.3 & 3.9 & 2.1 & 3.0 & 2.5 & 18.0 & 30 \\
\hline Jan-90 & 7 & 19.6 & 2.1 & 0.6 & 3.3 & 1.0 & 2.6 & 1.7 & 9.6 & 31 \\
\hline Jan -90 & 7 & 19.4 & 1.7 & 0.8 & 3.6 & 2.0 & 2.5 & 2.0 & $6.5^{5}$ & 32 \\
\hline Jan-90 & 7 & 18.5 & 1.7 & 0.4 & 2.9 & 1.0 & 1.8 & 1.5 & 11.6 & 33 \\
\hline May-90 & 7 & 17.2 & 2.0 & 0.4 & 2.6 & 0.6 & 1.9 & 1.5 & 5.0 & 40 \\
\hline May-94 & 3 & 22.7 & 3.9 & 0.7 & 4.1 & 1.5 & 3.4 & 2.8 & 346 & 35 \\
\hline Sep-94 & 3 & 21.8 & 1.9 & 0.8 & 2.8 & 1.2 & 2.5 & 1.6 & $1 \div 6$ & 38 \\
\hline Apr-95 & 2 & 24.0 & 4.5 & 1.8 & 4.6 & 1.3 & 3.8 & 3.6 & 17.3 & 7 \\
\hline
\end{tabular}


Appendix 1

Water Exposure Data

\begin{tabular}{|c|c|c|c|c|c|c|c|c|c|c|c|}
\hline \multicolumn{4}{|c|}{ Filter Sample } & \multirow{2}{*}{\multicolumn{2}{|c|}{$\frac{\text { Burst }}{\text { (PSI) }}$}} & \multirow{2}{*}{\multicolumn{2}{|c|}{$\begin{array}{c}\begin{array}{c}\text { Tensile - Machine } \\
\text { Direction }\end{array} \\
\text { (lb/in.-width) }\end{array}$}} & \multirow{2}{*}{\multicolumn{2}{|c|}{$\begin{array}{c}\begin{array}{c}\text { Tensile - Cross } \\
\text { Direction }\end{array} \\
\text { (lb/in.-width) }\end{array}$}} & \multirow{2}{*}{$\begin{array}{c}\text { Wet Tensile- } \\
\text { Machine } \\
\text { Direction } \\
\text { (Ib/in.-width) }\end{array}$} & \multirow{2}{*}{\begin{tabular}{|c|}
$\begin{array}{c}\text { Wet Tensile - } \\
\text { Machine } \\
\text { Direction Across } \\
\text { Fold }\end{array}$ \\
$\begin{array}{c}\text { (lb/in.-width) } \\
\end{array}$
\end{tabular}} \\
\hline & Date & Age & Thickness & & & & & & & & \\
\hline Sheet No. & Manufactured & (Years) & (Mils) & Before & After $\mathrm{H} 2 \mathrm{O}$ & Before & After $\mathrm{H} 2 \mathrm{O}$ & Before & After $\mathrm{H} 2 \mathrm{O}$ & & \\
\hline 9 & Sep-83 & 14 & 20.4 & 1.8 & 0.4 & 3.1 & 1.1 & 2.4 & 1.5 & 1.2 & 0.4 \\
\hline 12 & Sep-83 & 14 & 22.2 & 2.1 & 0.4 & 3.5 & 2.0 & 2.4 & 1.8 & 1.4 & 0.4 \\
\hline 41 & Sep-86 & 11 & 19.0 & 2.5 & 0.6 & 3.1 & 3.3 & 2.4 & 2.7 & 2.1 & 0.9 \\
\hline 13 & Oct-86 & 11 & 20.1 & 2.9 & 0.8 & 4.2 & 3.7 & 3.6 & 2.7 & 2.0 & 0.6 \\
\hline 15 & Oct-86 & 11 & 19.6 & 1.6 & 0.6 & 2.6 & 3.2 & 2.1 & 1.4 & 1.9 & 0.6 \\
\hline 27 & Oct-86 & 11 & 18.6 & 2.8 & 1.0 & 4.6 & 3.3 & 3.7 & 2.9 & 2.5 & 1.0 \\
\hline 34 & Dec-89 & 8 & 19.6 & 2.3 & 0.6 & 3.6 & 3.1 & 2.6 & 2.2 & 2.6 & 0.3 \\
\hline 39 & Dec-89 & 8 & 17.2 & 1.4 & 0.2 & 2.4 & 2.4 & 2.2 & 2.2 & 1.5 & 0.4 \\
\hline 21 & Jan-90 & 7 & 18.5 & 2.5 & 0.6 & 3.9 & 2.8 & 3.0 & 2.4 & 1.4 & 0.5 \\
\hline 29 & Jan-90 & 7 & 20.8 & 2.1 & 0.4 & 3.3 & 2.6 & 2.3 & 1.5 & 1.4 & 0.3 \\
\hline 30 & Jan-90 & 7 & 19.5 & 2.2 & 0.8 & 3.9 & 3.7 & 3.0 & 1.5 & 2.5 & 0.7 \\
\hline 31 & Jan-90 & 7 & 19.6 & 2.1 & 0.4 & 3.3 & 2.3 & 2.6 & 1.5 & 1.4 & 0.4 \\
\hline 32 & Jan-90 & 7 & 19.4 & 1.7 & 1.0 & 3.6 & 2.3 & 2.5 & 1.3 & 1.4 & 0.4 \\
\hline 33 & Jan-90 & 7 & 18.5 & 1.7 & 0.4 & 2.9 & 2.7 & 1.8 & 2.4 & 1.6 & 0.3 \\
\hline 7 & Apr-95 & 2 & 24.0 & 4.5 & 1.0 & 4.6 & 5.3 & 3.8 & 3.9 & 2.3 & 0.8 \\
\hline
\end{tabular}


Appendix 1

Water Data - Multiple Exposures

\begin{tabular}{|c|c|c|c|c|c|c|c|c|c|c|c|c|}
\hline \multicolumn{4}{|c|}{ Filter Sample } & \multicolumn{3}{|c|}{ Burst } & \multirow{2}{*}{\multicolumn{3}{|c|}{$\frac{\text { Tensile - Machine Direction }}{\text { (lb/in.-width) }}$}} & \multicolumn{3}{|c|}{ Tensile - Cross Direction } \\
\hline & Date & Age & Thickness & & (PSI) & & & & & & b/in.-widt & \\
\hline Sheet No. & Manufactured & (Years) & (Mils) & Initial & 1st H2O & 2nd $\mathrm{H} 2 \mathrm{O}$ & Initial & 1st $\mathrm{H} 2 \mathrm{O}$ & 2nd H2O & Initial & 1 st $\mathrm{H} 2 \mathrm{O}$ & 2nd $\mathrm{H} 2 \mathrm{O}$ \\
\hline $\begin{array}{c}10 \\
\text { (Unused) }\end{array}$ & Aug-82 & 15 & 18.9 & 2.4 & 2.0 & & 3.3 & 2.1 & & 2.5 & 2.0 & \\
\hline $\begin{array}{l}11 \text { (Dust } \\
\text { Loaded) }\end{array}$ & Nov-84 & 13 & 19.0 & 2.0 & 1.6 & 0.6 & 4.7 & 1.7 & 2.8 & 3.4 & 1.4 & 1.0 \\
\hline $\begin{array}{l}28 \text { (Dust } \\
\text { Loaded) }\end{array}$ & Oct-86 & 11 & 20.3 & 3.6 & 4.4 & 0.8 & 5.1 & 3.7 & 3.5 & 3.9 & 2.4 & 2.5 \\
\hline $\begin{array}{l}22 \text { (Dust } \\
\text { Loaded) }\end{array}$ & Jan-90 & 7 & 20.3 & 2.1 & 1.4 & 0.6 & 3.8 & 3.1 & 2.5 & 2.7 & 2.1 & 1.6 \\
\hline $\begin{array}{c}19 \\
\text { (Unused) }\end{array}$ & May-94 & 3 & 22.1 & 2.9 & 2.2 & & 4.9 & 2.1 & & 3.3 & 1.9 & \\
\hline $\begin{array}{c}20 \\
\text { (Unused) }\end{array}$ & Jan-96 & 1 & 15.6 & 6.1 & 3.6 & & 4.9 & 3.2 & & 4.9 & 1.6 & \\
\hline
\end{tabular}


Appendix 1

Used Clean Filter Data

\begin{tabular}{|c|c|c|c|c|c|c|c|c|c|c|}
\hline Date & Age & Thickness & Burst & $\begin{array}{l}\text { Burst } \\
\text { Across } \\
\text { Fold }\end{array}$ & $\begin{array}{l}\text { Tensile - } \\
\text { Machine } \\
\text { Direction }\end{array}$ & $\begin{array}{c}\text { Tensile - } \\
\text { Machine } \\
\text { Direction Across } \\
\text { Fold }\end{array}$ & $\begin{array}{c}\text { Tensile - Cross } \\
\text { Direction }\end{array}$ & $\begin{array}{c}\text { Tensile - Cross } \\
\text { Direction Across } \\
\text { Fold }\end{array}$ & Water Ropollency & Sample APO \\
\hline Manufactured & (Years) & (Mils) & (PSI) & (PSI) & (lb/in.-width) & (lb/in.-width) & (lb/in.-width) & (lb/in.-width) & (Inches (ater) & NO. 97 P1466- \\
\hline Mar-81 & 16 & 20.0 & 2.8 & 1.5 & 4.8 & & 3.3 & 0.8 & 21.5 & 11 \\
\hline Mar-81 & 16 & 20.0 & 7.0 & 2.2 & 7.0 & & 3.4 & 3.4 & 20.0 & 10 \\
\hline Mar-81 & 16 & 20.0 & 3.8 & 1.5 & 5.2 & 1.3 & 3.8 & 2.6 & 25.0 & 5 \\
\hline May-81 & 16 & 24.0 & $15.0+$ & $15.0+$ & 11.0 & 10.2 & 5.4 & 2.8 & 15.5 & 16 \\
\hline Aug-81 & 16 & 21.0 & 2.8 & 1.6 & 5.4 & 0.4 & 3.1 & 2.3 & 29.0 & 21 \\
\hline Aug-81 & 16 & 19.0 & 4.0 & 1.0 & 5.2 & 0.7 & 4.0 & 2.3 & 18.0 & 19 \\
\hline $\operatorname{Jan}-82$ & 15 & 20.0 & 2.4 & 2.2 & 2.9 & 0.7 & 2.0 & 1.5 & 23.0 & 4 \\
\hline Aug-82 & 15 & 19.0 & 4.0 & 1.5 & 3.7 & 2.1 & 6.0 & 4.0 & 30.0 & 20 \\
\hline Jun-83 & 14 & 14.0 & 6.2 & 2.5 & 2.5 & 0.7 & 3.8 & 2.1 & 6.0 & 12 \\
\hline Aug-83 & 14 & 18.0 & 7.8 & 4.6 & 7.0 & 2.2 & 4.7 & 4.5 & 41.0 & 23 \\
\hline Aug-83 & 14 & 19.0 & 6.8 & 3.8 & 7.2 & 1.8 & 5.4 & 5.0 & 42.0 & 24 \\
\hline Aug-83 & 14 & 18.0 & 8.8 & 4.0 & 5.7 & 1.1 & 4.1 & 3.0 & 19.0 & 17 \\
\hline Aug-83 & 14 & 19.0 & 5.2 & 3.2 & 5.2 & 2.2 & 4.5 & 3.8 & 25.0 & 18 \\
\hline Oct -83 & 14 & 18.0 & 9.2 & 2.6 & 5.4 & 3.2 & 3.9 & 3.0 & 19.5 & 14 \\
\hline Jan-84 & 13 & 18.0 & 5.8 & 2.0 & 3.9 & 1.6 & 3.4 & & 18.5 & 9 \\
\hline Jan-84 & 13 & 19.0 & 7.8 & 3.2 & 8.0 & 3.0 & 4.3 & 1.1 & 36.0 & 3 \\
\hline $\operatorname{Jan}-84$ & 13 & 20.0 & 8.5 & 3.8 & 5.7 & 2.0 & 4.9 & 4.8 & 31.0 & 1 \\
\hline Jan-84 & 13 & 19.0 & 8.2 & 4.0 & 7.2 & 3.6 & 6.2 & 5.1 & 38.0 & 7 \\
\hline Mar-84 & 13 & 19.0 & 6.0 & 2.5 & 3.6 & 1.1 & 4.1 & 2.5 & 28.0 & 13 \\
\hline Mar-84 & 13 & 19.0 & 6.0 & 3.2 & 4.0 & 1.7 & 4.7 & 4.1 & 24.0 & 15 \\
\hline Jan-86 & 11 & 19.0 & 6.8 & 3.8 & 5.8 & 2.4 & 5.7 & 4.5 & 41.0 & 2 \\
\hline Oct-89 & 8 & 17.0 & 7.0 & 4.0 & 5.0 & 0.7 & 4.3 & 3.4 & 39.0 & 6 \\
\hline
\end{tabular}




\section{Appendix 1}

Used LLW Filter Data

\begin{tabular}{|c|c|c|c|c|c|c|c|c|}
\hline Date & Age & Thickness & Burst & $\begin{array}{c}\text { Burst Across } \\
\text { Fold } \\
\end{array}$ & $\begin{array}{l}\text { Tensile - } \\
\text { Machine } \\
\text { Direction }\end{array}$ & $\begin{array}{c}\text { Tensile - } \\
\text { Machine } \\
\text { Direction } \\
\text { Across Fold }\end{array}$ & $\begin{array}{c}\text { Tensile - Cross } \\
\text { Direction }\end{array}$ & Sample APO \\
\hline Manufactured & (Years) & (Mils) & (PSI) & (PSI) & (lb/in.-width) & (lb/in.-width) & (lb/in.-width) & No. 97P1702- \\
\hline Feb-72 & 25 & 16.0 & 3.1 & & 3.8 & 0.4 & 1.8 & 3 \\
\hline Aug-72 & 25 & 19.0 & 1.6 & 0.8 & 1.0 & 0.1 & 1.0 & 5 \\
\hline Oct-72 & 25 & 17.0 & 3.1 & 1.8 & 6.0 & 1.2 & 2.1 & 4 \\
\hline Sep-73 & 24 & 22.0 & 3.0 & 0.8 & 3.7 & 0.6 & 2.3 & 34 \\
\hline Jan-74 & 23 & 17.0 & 3.2 & 2.0 & 4.6 & 0.8 & 1.9 & 30 \\
\hline Jan-74 & 23 & 16.0 & 1.2 & 1.2 & 3.8 & 1.0 & 1.4 & 31 \\
\hline Jan-74 & 23 & 16.0 & 1.8 & 1.0 & 4.1 & 0.1 & 1.8 & 32 \\
\hline Jan-74 & 23 & 24.0 & 3.0 & 2.0 & 5.3 & 0.6 & 5.1 & 39 \\
\hline $\operatorname{Jan-74}$ & 23 & 17.0 & 1.8 & 1.0 & 3.6 & 0.7 & 2.7 & 52 \\
\hline Jan-74 & 23 & 17.0 & 2.2 & 1.0 & 3.6 & 1.0 & 1.5 & 53 \\
\hline Dec-80 & 17 & 18.0 & 8.8 & 4.0 & 4.7 & 3.8 & 5.7 & 10 \\
\hline Jan-81 & 16 & 18.0 & 7.8 & 1.6 & 6.5 & 0.6 & 4.8 & 47 \\
\hline Jul-81 & 16 & 21.0 & 3.0 & 1.6 & 7.1 & 2.1 & 3.6 & 48 \\
\hline Jul-83 & 14 & 18.0 & 7.8 & 2.0 & 5.3 & 0.3 & 3.9 & 55 \\
\hline Aug-83 & 14 & 20.0 & 2.0 & 1.0 & 2.4 & 0.3 & 2.7 & 18 \\
\hline Aug-83 & 14 & 22.0 & 2.3 & 1.0 & 4.3 & 0.4 & 2.8 & 19 \\
\hline Aug-83 & 14 & 21.0 & 1.8 & 0.8 & 2.1 & & 1.3 & 20 \\
\hline Aug-83 & 14 & 20.0 & 2.0 & 0.8 & 1.1 & 0.1 & 0.6 & 21 \\
\hline Sep-83 & 14 & 20.0 & 5.8 & 2.6 & 4.3 & 1.6 & 4.7 & 16 \\
\hline Sep-83 & 14 & 18.0 & 5.2 & 3.2 & 3.5 & 0.5 & 3.5 & 17 \\
\hline Sep-83 & 14 & 20.0 & 3.2 & & 5.2 & 1.6 & 4.6 & 2 \\
\hline Sep-83 & 14 & 19.0 & 6.4 & 3.2 & 5.3 & 0.3 & 5.4 & 1 \\
\hline Sep-83 & 14 & 18.0 & 8.0 & 3.0 & 5.1 & 0.6 & 3.2 & 22 \\
\hline Sep-83 & 14 & 17.0 & 4.6 & 1.6 & 5.4 & 0.4 & 2.8 & 23 \\
\hline Oct-83 & 14 & 19.0 & 2.0 & 2.0 & 3.0 & 0.1 & 1.6 & 61 \\
\hline Apr-84 & 13 & 21.0 & 6.0 & 1.6 & 6.7 & 0.3 & 4.8 & 50 \\
\hline Apr -84 & 13 & 21.0 & 4.6 & 2.2 & 6.2 & 0.5 & 5.1 & 51 \\
\hline Apr -84 & 13 & 20.0 & 5.0 & 1.0 & 2.8 & 0.4 & 0.6 & 49 \\
\hline Jul-84 & 13 & 17.0 & 1.6 & 1.2 & 1.4 & 0.4 & 1.3 & 58 \\
\hline Jul-84 & 13 & 21.0 & 4.0 & 1.4 & 5.4 & 0.1 & 2.8 & 57 \\
\hline Feb-85 & 12 & 21.0 & 4.2 & 1.8 & 5.6 & 0.1 & 4.0 & 63 \\
\hline Jun-85 & 12 & 21.0 & 3.6 & 3.8 & 4.5 & 0.1 & 2.3 & 45 \\
\hline Jun-85 & 12 & 22.0 & 4.2 & 1.6 & 7.6 & 0.1 & 5.6 & 46 \\
\hline
\end{tabular}




\section{Appendix 1}

Used LLW Filter Data

\begin{tabular}{|c|c|c|c|c|c|c|c|c|}
\hline Date & Age & Thickness & Burst & $\begin{array}{c}\text { Burst Across } \\
\text { Fold } \\
\end{array}$ & $\begin{array}{l}\text { Tensile - } \\
\text { Machine } \\
\text { Direction }\end{array}$ & $\begin{array}{c}\text { Tensile - } \\
\text { Machine } \\
\text { Direction } \\
\text { Across Fold }\end{array}$ & $\begin{array}{c}\text { Tensile - Cross } \\
\text { Direction }\end{array}$ & Sample APO \\
\hline Manufactured & (Years) & (Mils) & (PSI) & (PSI) & (lb/in.-width) & (lb/in.-width) & (lb/in.-width) & No.97P1702- \\
\hline Jun-85 & 12 & 21.0 & 7.2 & 4.0 & 2.1 & 2.1 & 4.8 & 15 \\
\hline Jul-85 & 12 & 21.0 & 3.8 & 3.0 & 6.3 & 0.9 & 3.9 & 44 \\
\hline Jul-85 & 12 & 23.0 & 5.0 & 3.0 & 2.2 & 0.4 & 1.6 & 62 \\
\hline Jul-86 & 11 & 24.0 & 3.2 & 0.8 & 4.4 & 1.3 & 5.6 & 33 \\
\hline Oct -87 & 10 & 21.0 & 3.0 & 1.2 & 4.5 & 0.1 & 3.4 & 42 \\
\hline Dec-87 & 10 & 18.0 & 5.8 & 1.8 & 6.0 & 1.7 & 4.6 & 29 \\
\hline $\operatorname{Jan}-88$ & 9 & 21.0 & 4.0 & 1.2 & 2.2 & 1.2 & 2.2 & 28 \\
\hline Jan-88 & 9 & 23.0 & 2.4 & 1.8 & 3.2 & 0.1 & 3.8 & 35 \\
\hline Jun-88 & 9 & 22.0 & 2.1 & 1.8 & 6.1 & 0.4 & 5.4 & 6 \\
\hline Jun-88 & 9 & 20.0 & 3.0 & 2.0 & 7.2 & 0.1 & 5.0 & 12 \\
\hline Sep-88 & 9 & 19.0 & 6.2 & 3.2 & 5.0 & 0.7 & 5.0 & 13 \\
\hline Sep-88 & 9 & 19.0 & 3.5 & 0.2 & 4.0 & 0.4 & 3.0 & 14 \\
\hline Feb-89 & 8 & 17.0 & 6.8 & 2.4 & 5.2 & 0.7 & 3.7 & 60 \\
\hline Jul-89 & 8 & 18.0 & 3.8 & 2.8 & 7.4 & 0.6 & 3.9 & 59 \\
\hline Aug-89 & 8 & 19.0 & 6.0 & 3.0 & 4.6 & 1.4 & 3.7 & 11 \\
\hline Aug-89 & 8 & 19.0 & 5.8 & 1.6 & 4.5 & 0.3 & 3.5 & 27 \\
\hline Sep-89 & 8 & 19.0 & 5.6 & 2.2 & 3.5 & 0.4 & 3.7 & 26 \\
\hline Nov-89 & 8 & 23.0 & 2.0 & 0.2 & 3.6 & 0.7 & 1.0 & 38 \\
\hline Dec-89 & 8 & 19.0 & 1.6 & 1.4 & 3.6 & 0.4 & 4.4 & 37 \\
\hline Feb-90 & 7 & 19.0 & 2.0 & 2.0 & 5.6 & 0.5 & 7.0 & 7 \\
\hline Aug-90 & 7 & 18.0 & 2.0 & 1.1 & 3.0 & 0.1 & 1.7 & 8 \\
\hline Oct-90 & 7 & 17.0 & 1.4 & 0.8 & 1.2 & 0.1 & 1.3 & 43 \\
\hline Nov-90 & 7 & 17.0 & 2.2 & 1.0 & 1.7 & 0.1 & 1.5 & 36 \\
\hline Nov-90 & 7 & 16.0 & 2.0 & 0.2 & $2.5, \cdots$ & 0.1 & 2.0 & 54 \\
\hline Nov-90 & 7 & 19.0 & 0.2 & 0.2 & 1.3 & 0.1 & 1.8 & 56 \\
\hline Apr-91 & 6 & 18.0 & 2.2 & 1.0 & 4.4 & 0.4 & 3.5 & 24 \\
\hline Apr-91 & 6 & 20.0 & 2.0 & 1.0 & 1.3 & 0.1 & 1.6 & 25 \\
\hline Sep-91 & 6 & 21.0 & 4.2 & 1.8 & 3.2 & 0.2 & 2.3 & 9 \\
\hline
\end{tabular}




\section{APPENDIX 2}

Water Repellency Tests 
Appendix 2

Water Repellengy Tests
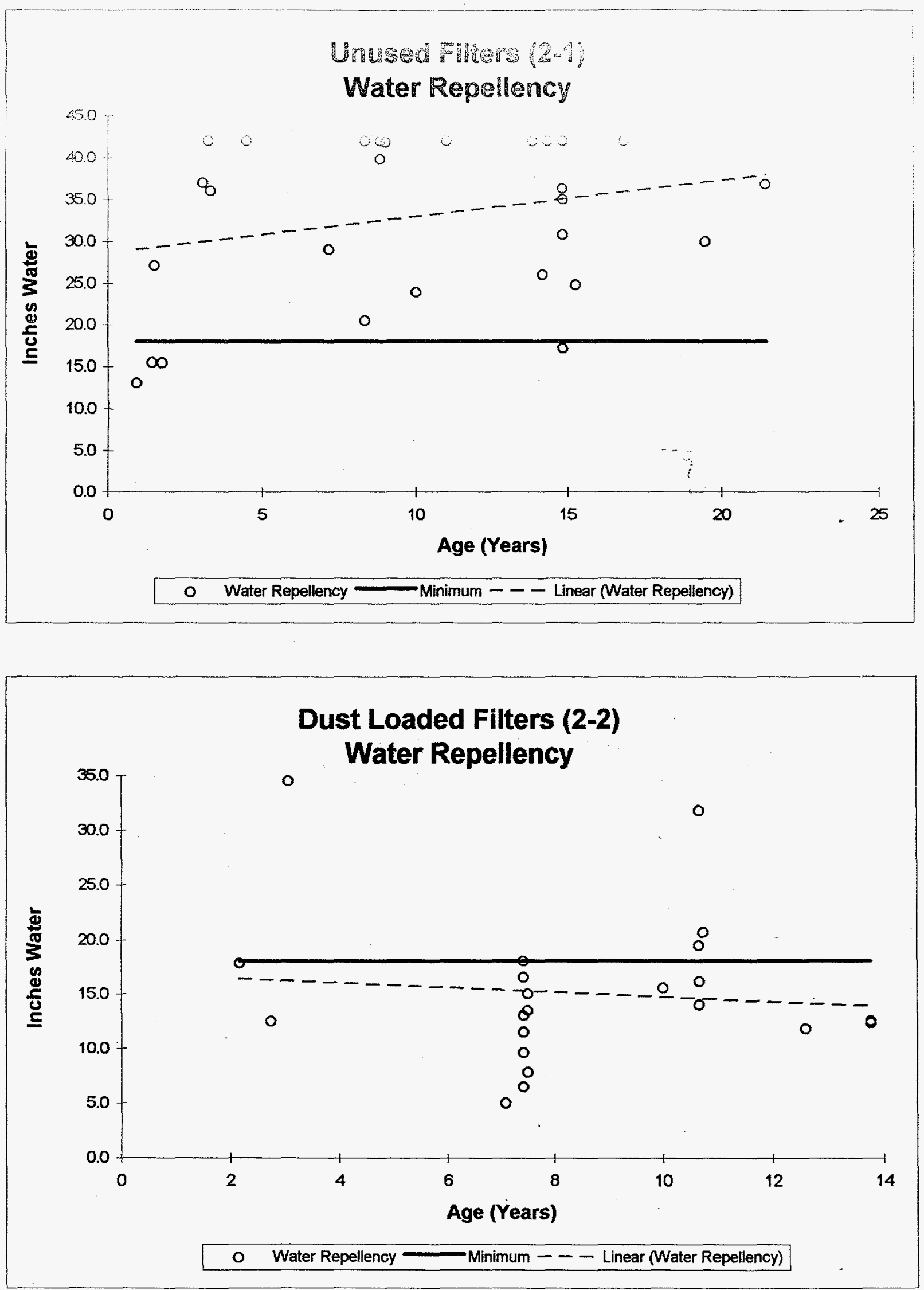
Appendix 2

Mater Repellency Trests

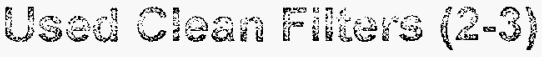 \\ Water Pepellency}

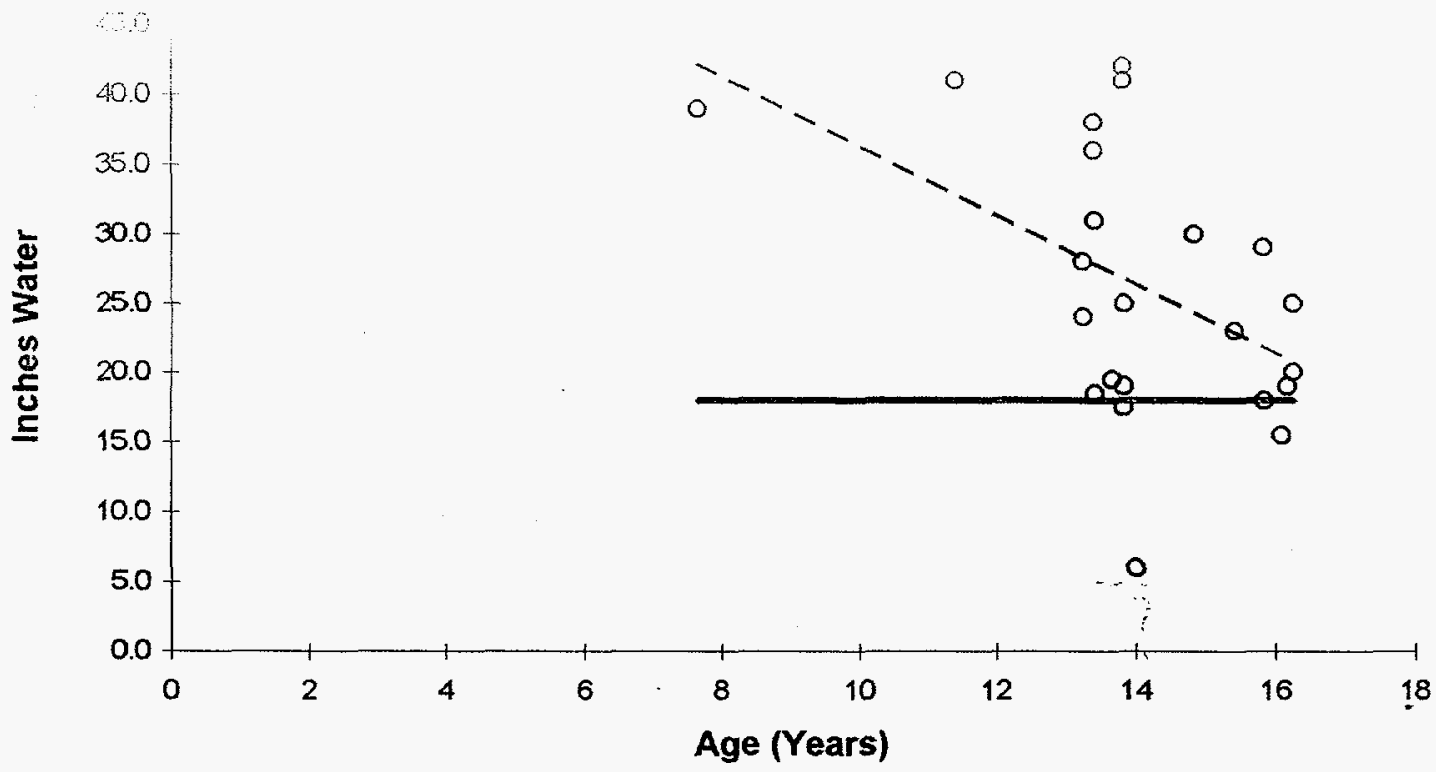

o Water Repellency $\longrightarrow$ Minimum - - Linear (Water Repellency) 


\section{APPENDIX 3}

Water Degradation Tests 

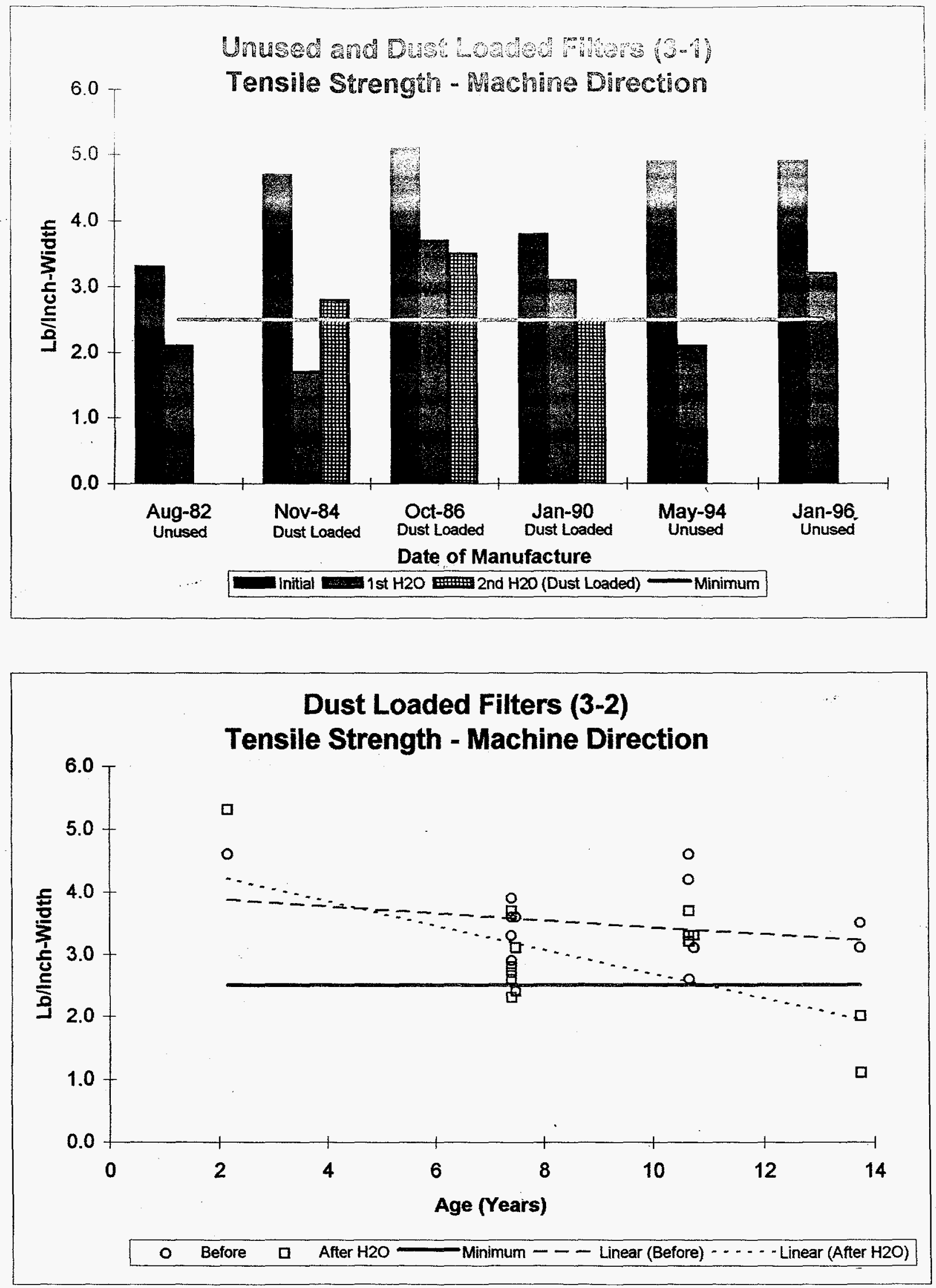
Appendix 3

Water Degrawain Tests

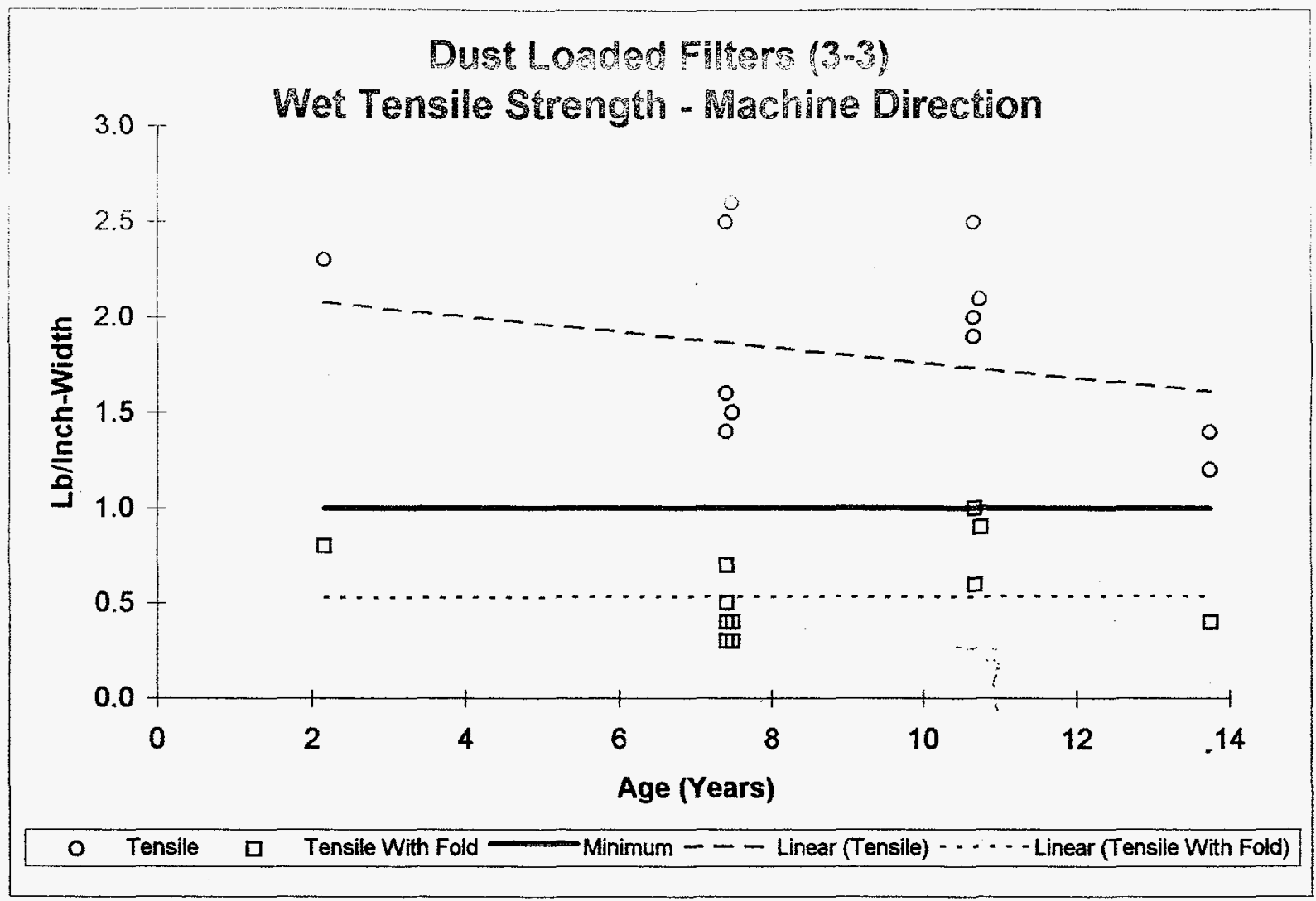


APPENDIX 4

Tensile Strength Tests 
Appendix 4

Tensile Strength Tests
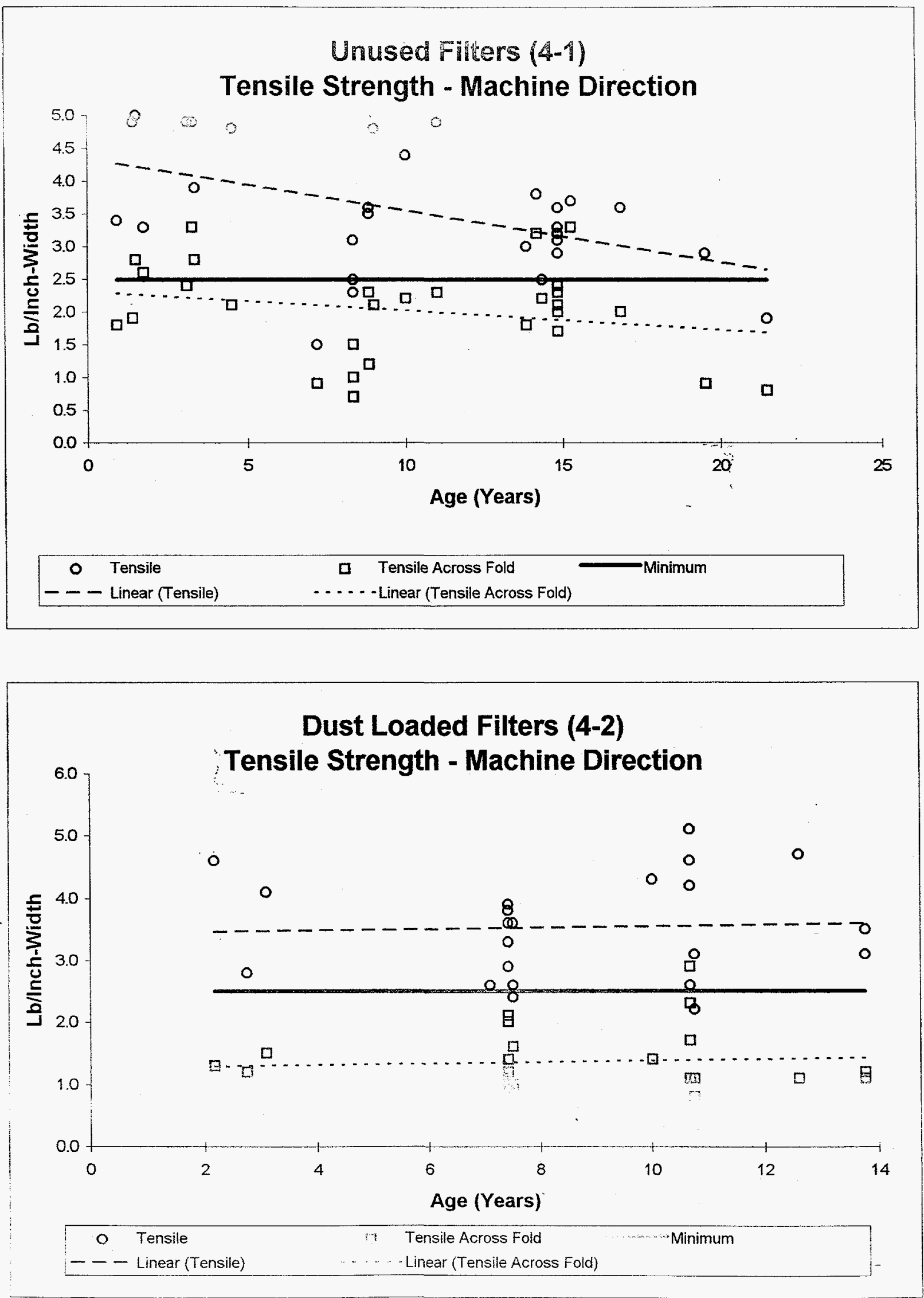

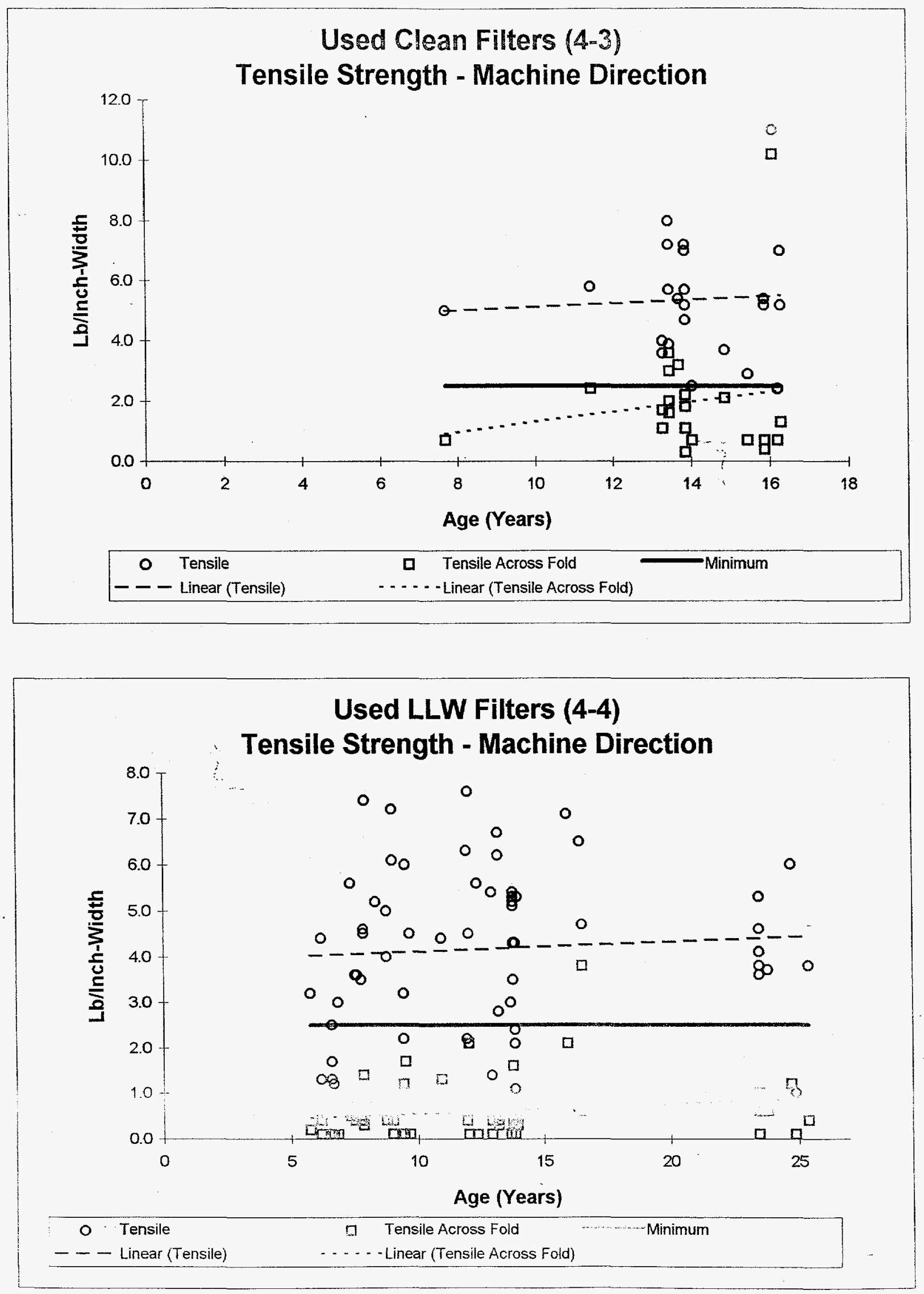


\section{APPENDIX 5}

Burst Pressure Tests 
Appendix 5

Burst Pressure Tests
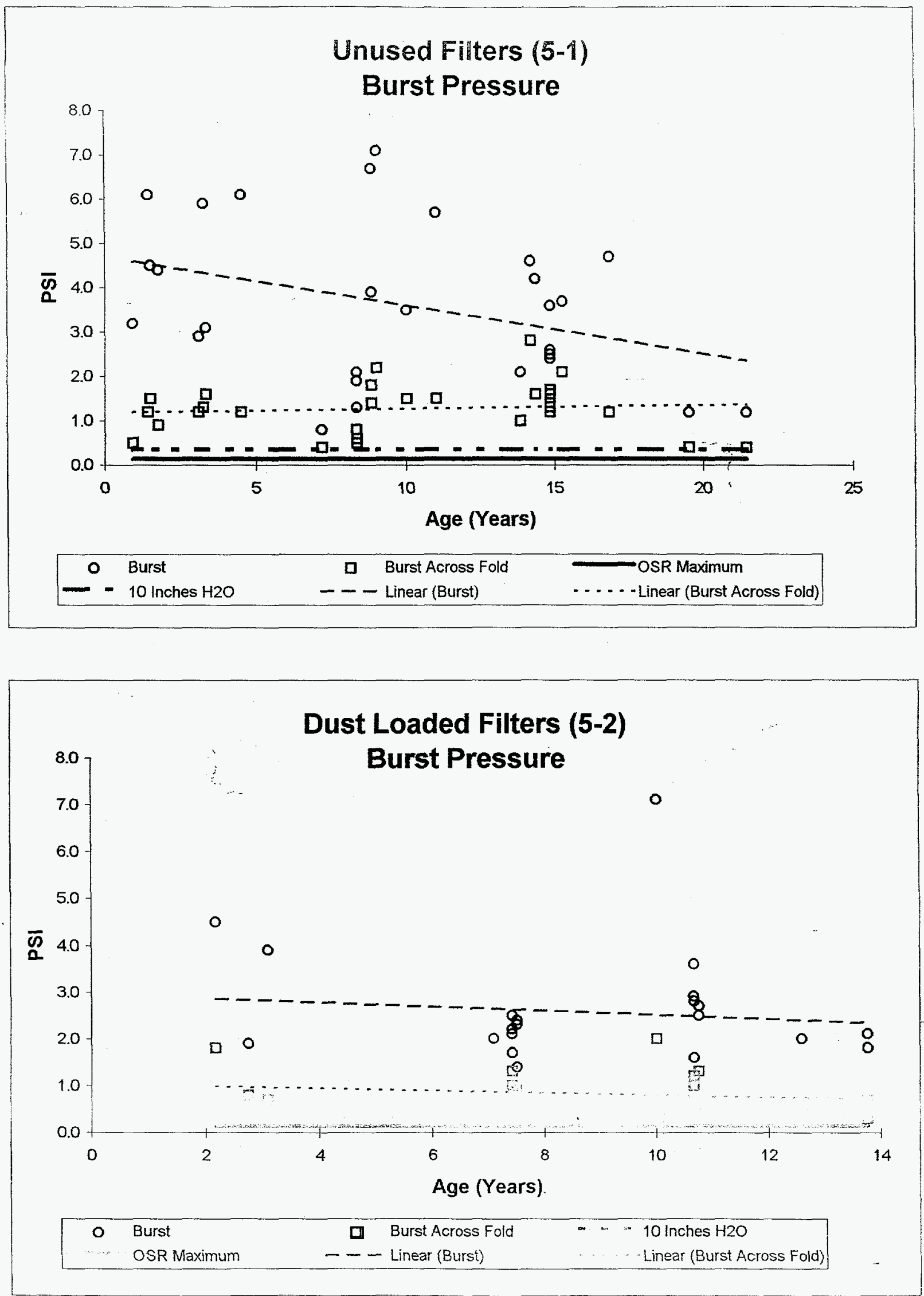
Appendix 5

Burst Pressure Tests
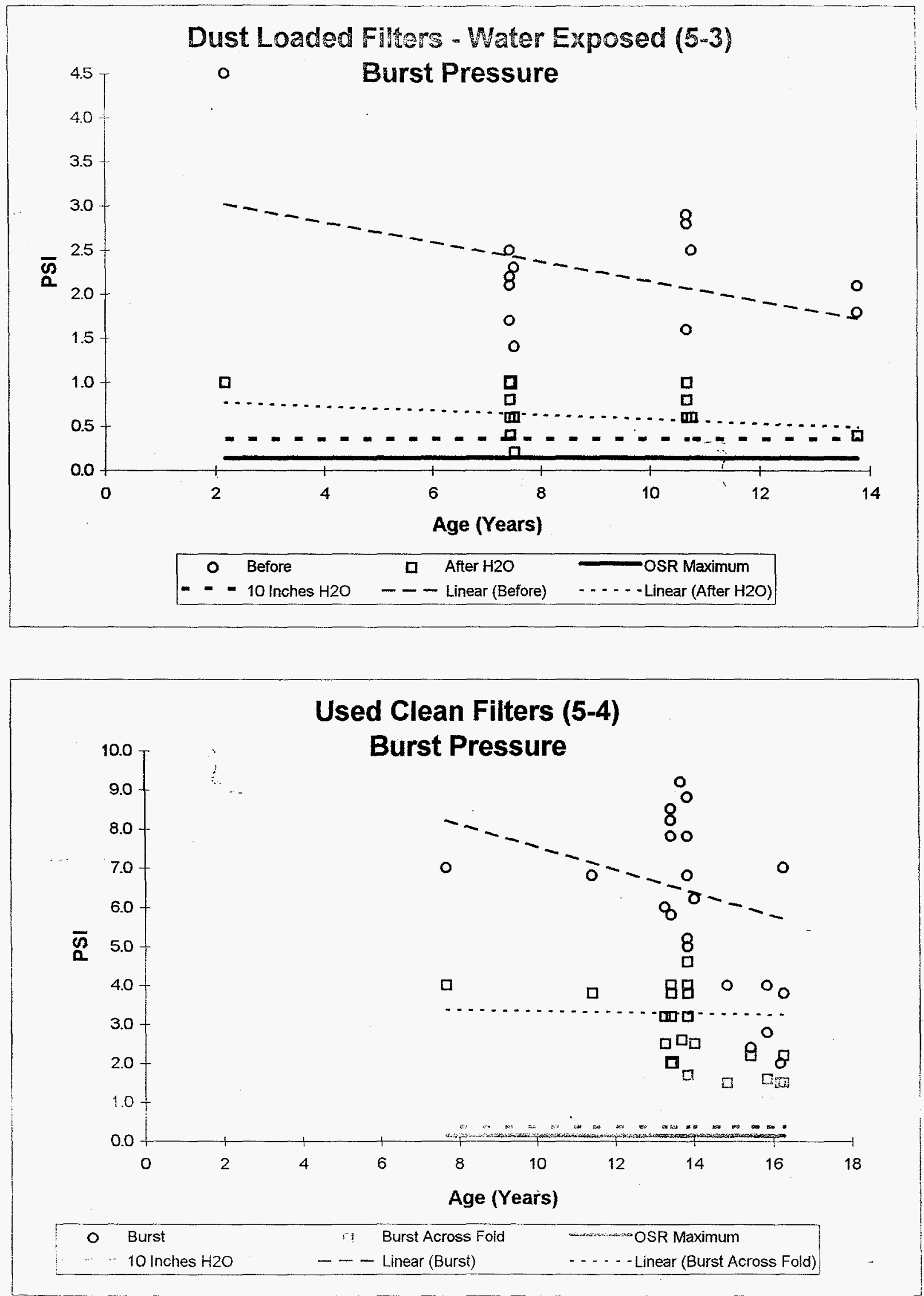
Appendix 5

Burst Pressure Tests

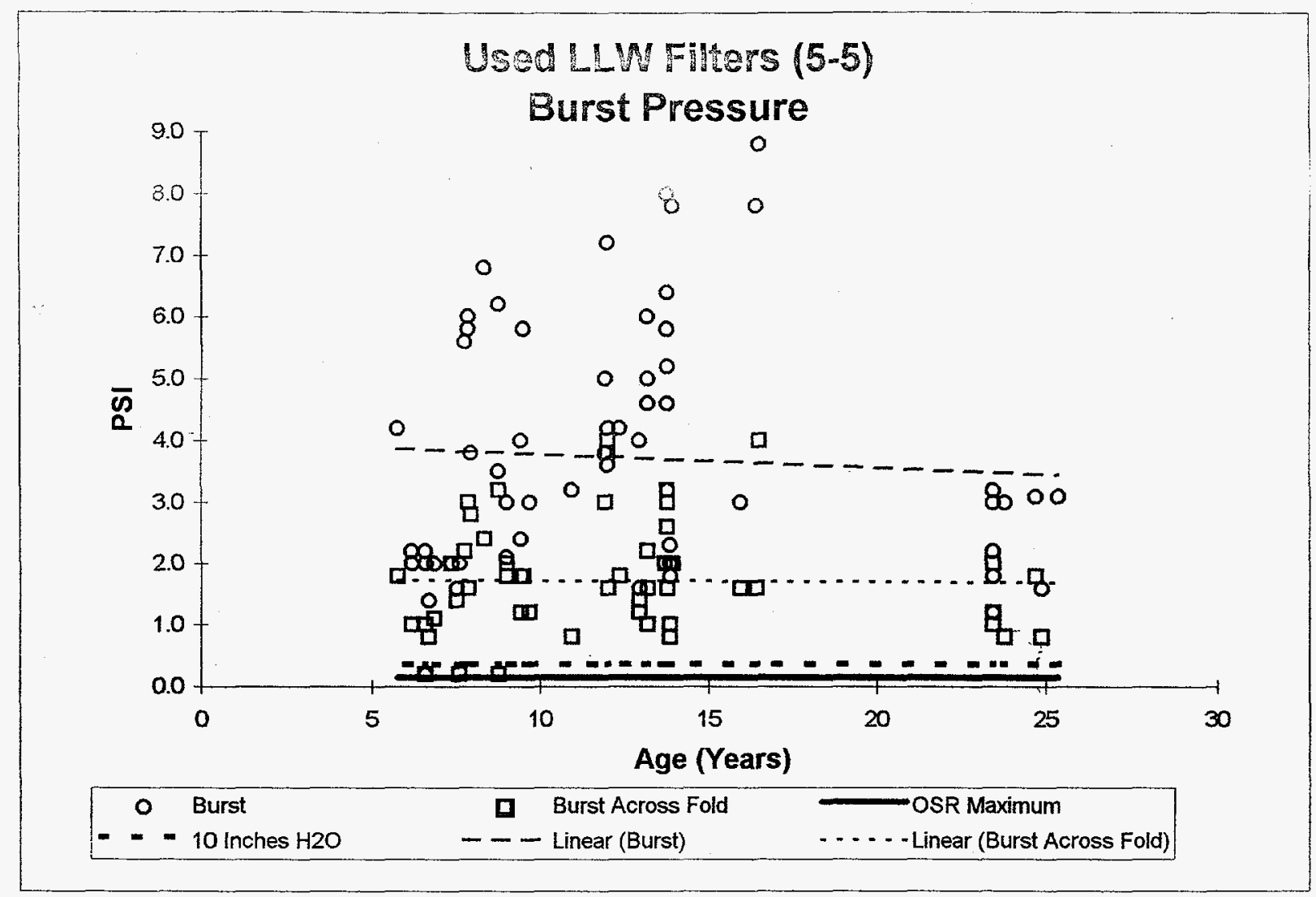


APPENDIX 6

Manufacturer Variances 
Appendix 6

Manufacturer Variances
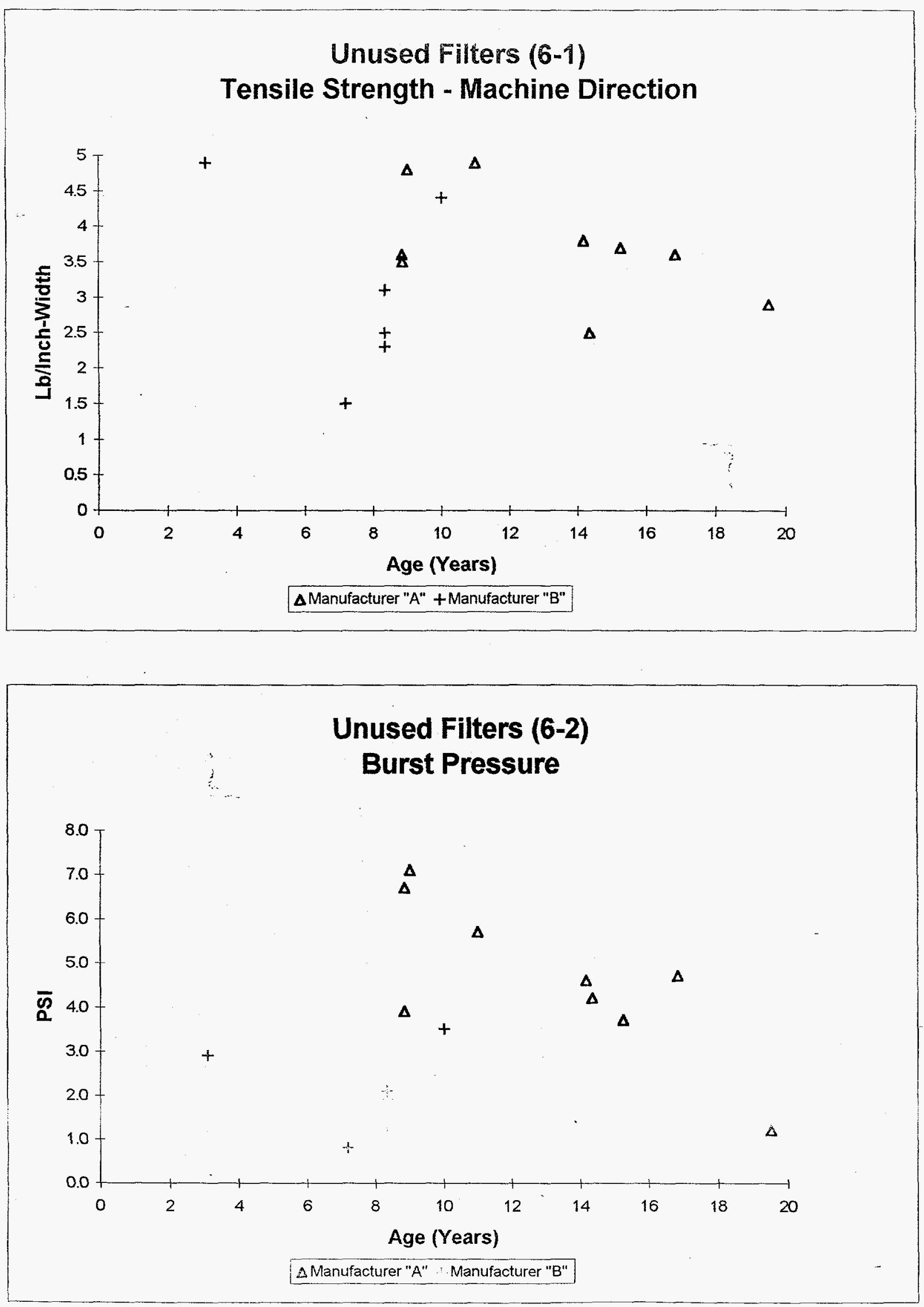
Appendix 6

Manufacturer Variances
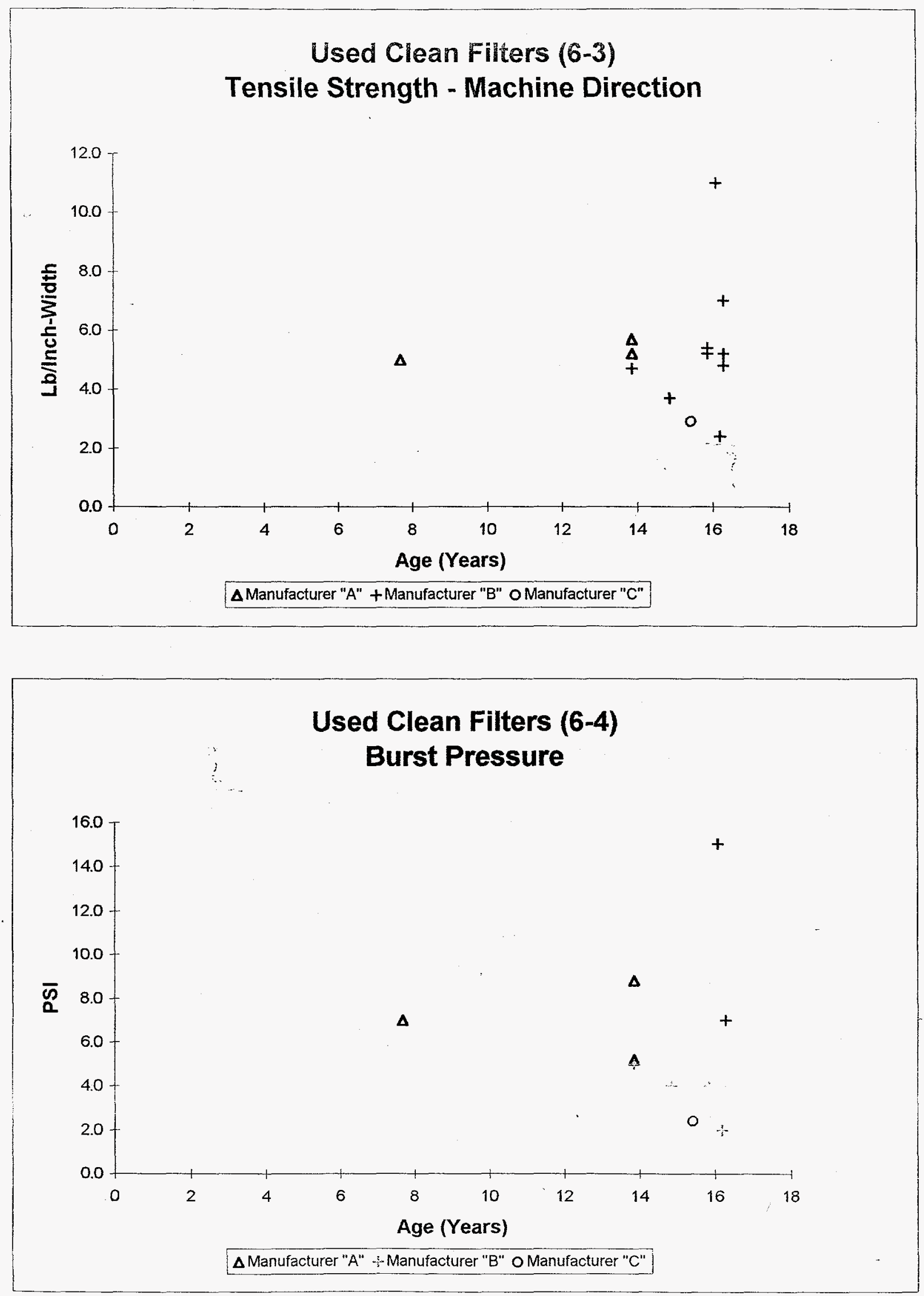
Appendix 6

Manufacturer Variances

\section{LLW Filters (6-5) \\ Tensile Strength - Machine Direction}

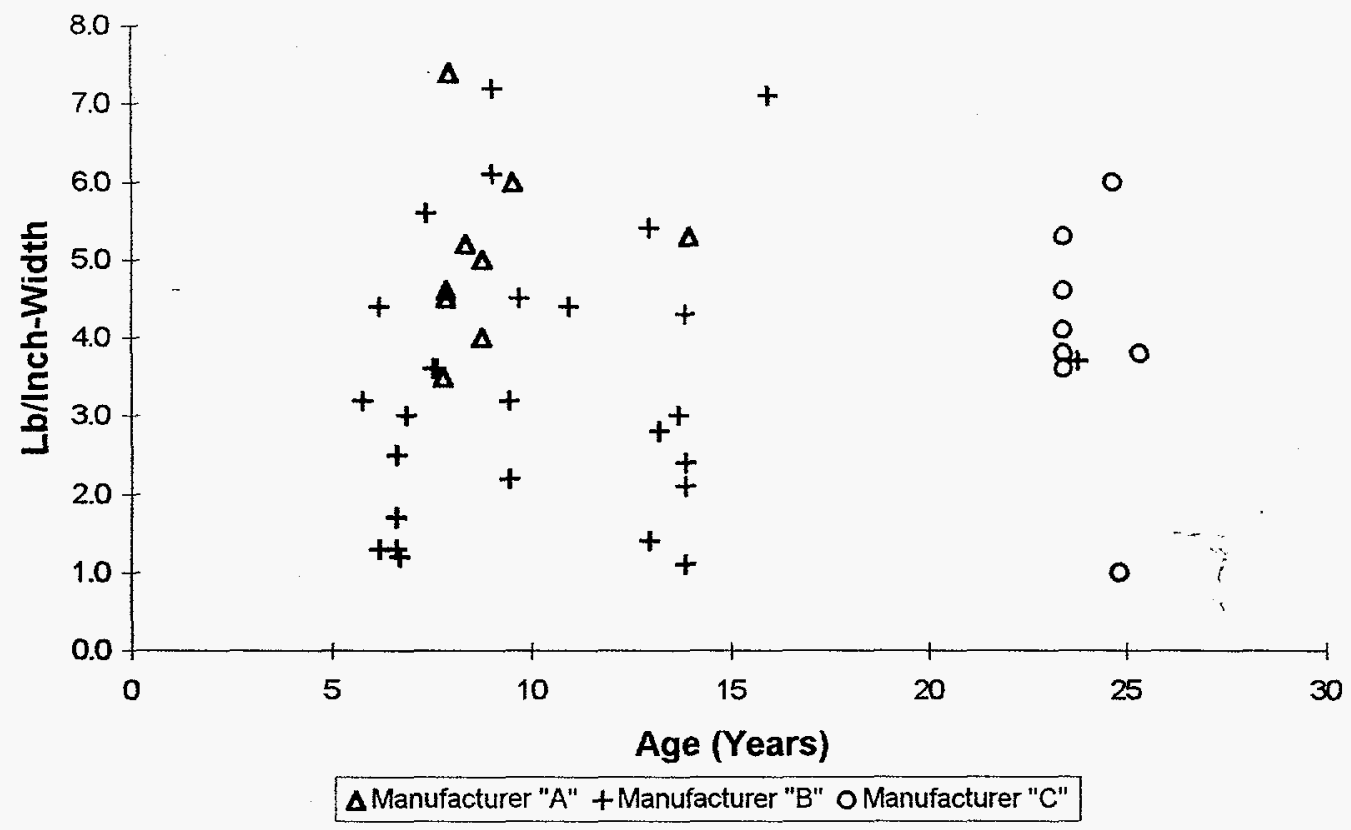

\section{LLW Filters (6-6) \\ Burst Pressure}

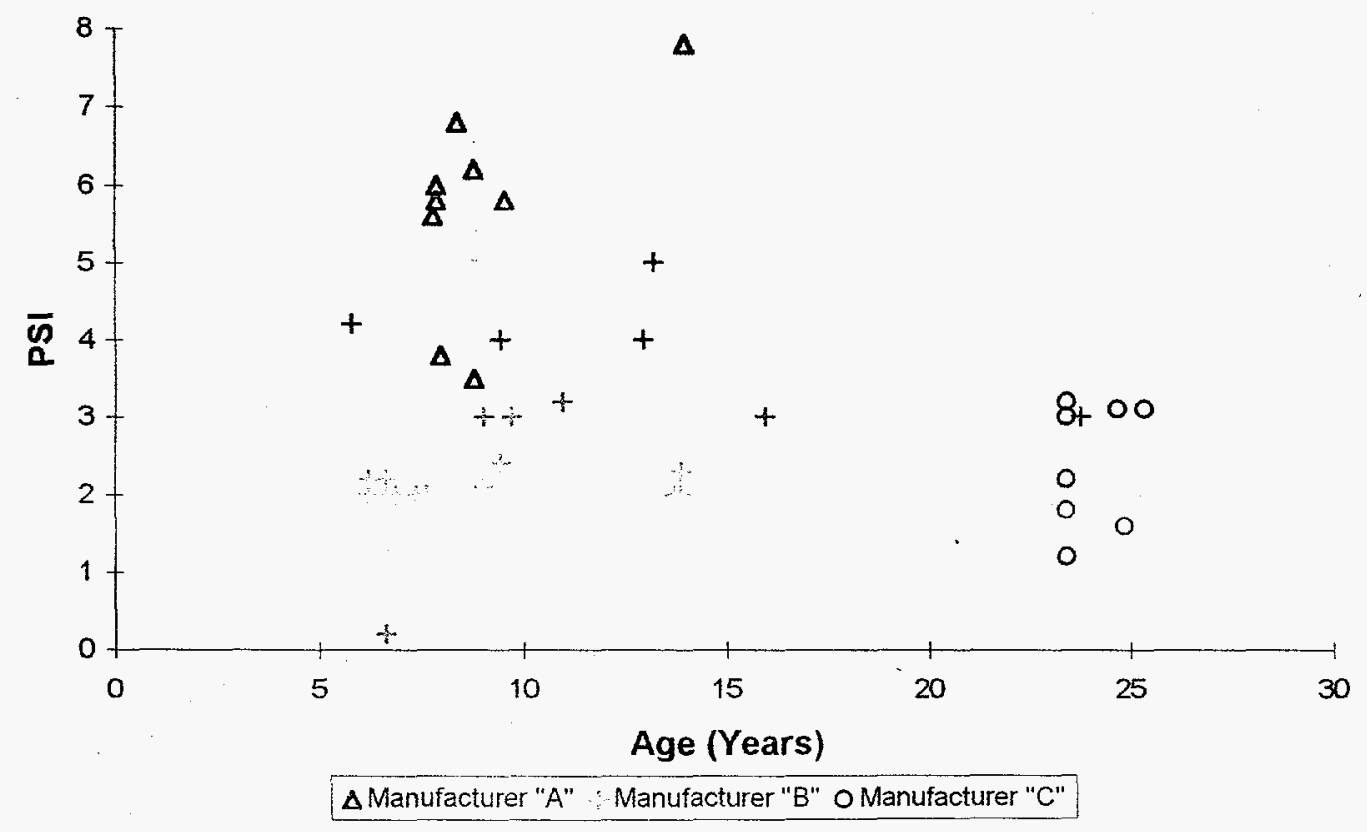




\title{
APPENDIX 7
}

\author{
Photographs
}

1) Filter with sample removed Building 442

2) Filter with sample removed Building 442

3) Filter with sample removed Building 442

4) Test equipment (left to right) Micrometer B-442, Water Repellency tester B-442 \& B-771, Tensile tester B-707

5) Tensile tester Building 442

6) Water Repellency tester B-442 \& B-771

7) Burst tester B-442 \& B-707

8) Low Level Waste (LLW) crates moved from 664 Area to 750 Pad, Tent 5

9) Permacon located in Tent 5, 750 Pad

10) C-Cell \& Glovebag in Permacon, 750 Pad

11) Sampling of filter in glovebag, 750 Pad

12) Test sample preparation in glovebag, 750 Pad

13) Test glovebox Building 707

14) Test glovebox Building 707

15) Burst testing in test glovebox Building 707

16) Tensile testing in test glovebox Building 707

17) Tensile testing in test glovebox Building 707

18) Test samples - tensile strength Machine Direction (MD)

19) Test samples - tensile strength Machine Direction (MD) on fold

20) Test samples - tensile strength Cross Direction (CD) on fold

21) Test samples - burst strength on flat

22) Test samples - burst strength on fold

23) Test samples - tensile strength Machine Direction (MD) \& Cross Direction (CD) after wet/dry treatment

24) Pressure Test Unit, Building 442

25) Dust (fly ash) loaded filter - Failed, Building 442

26) Filter subjected to water spray - Failed, Building 442 


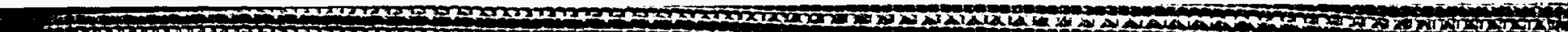
in

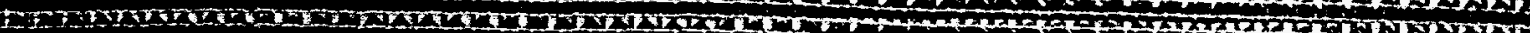

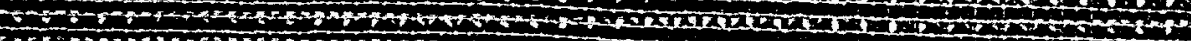

Q

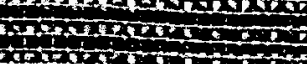

(1) 1.

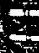

5

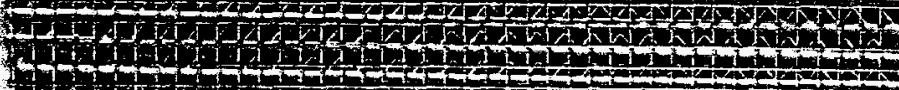

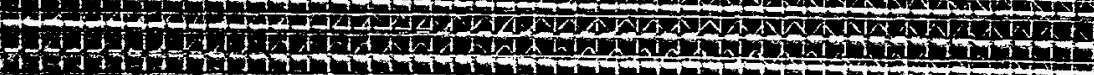

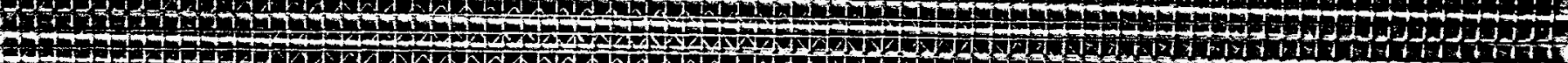

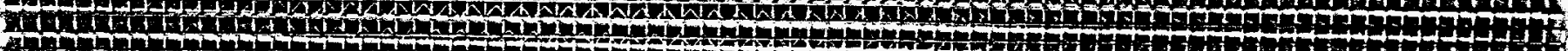
L

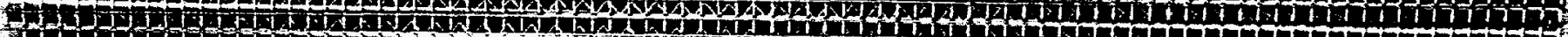

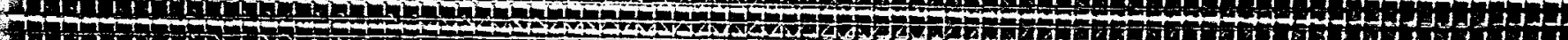

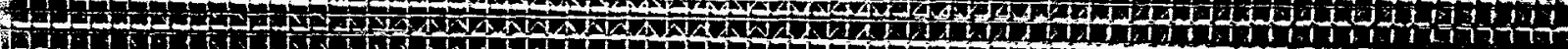

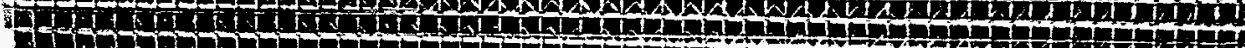

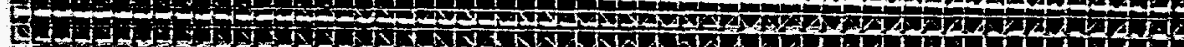

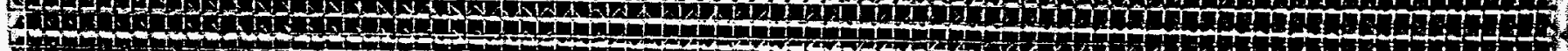
11 Dith

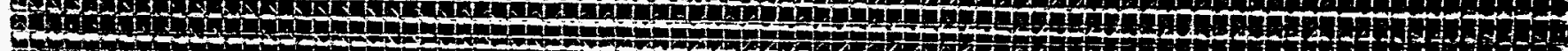

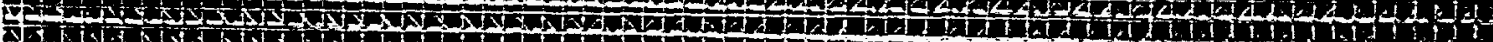

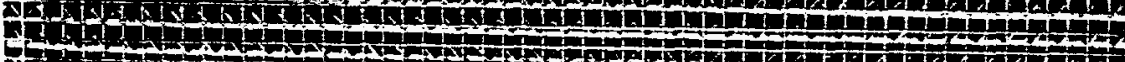

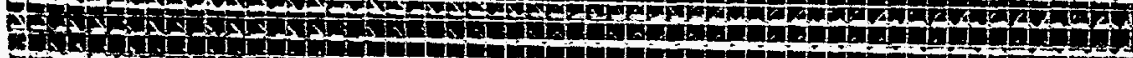

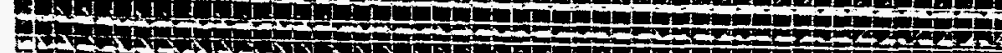

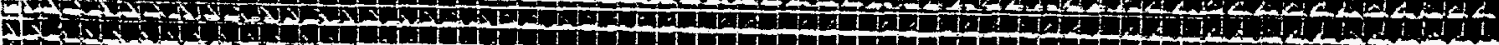

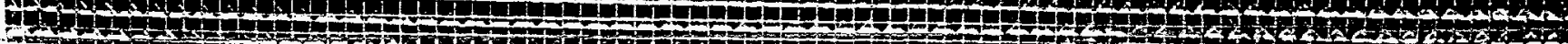

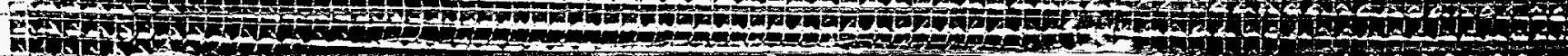

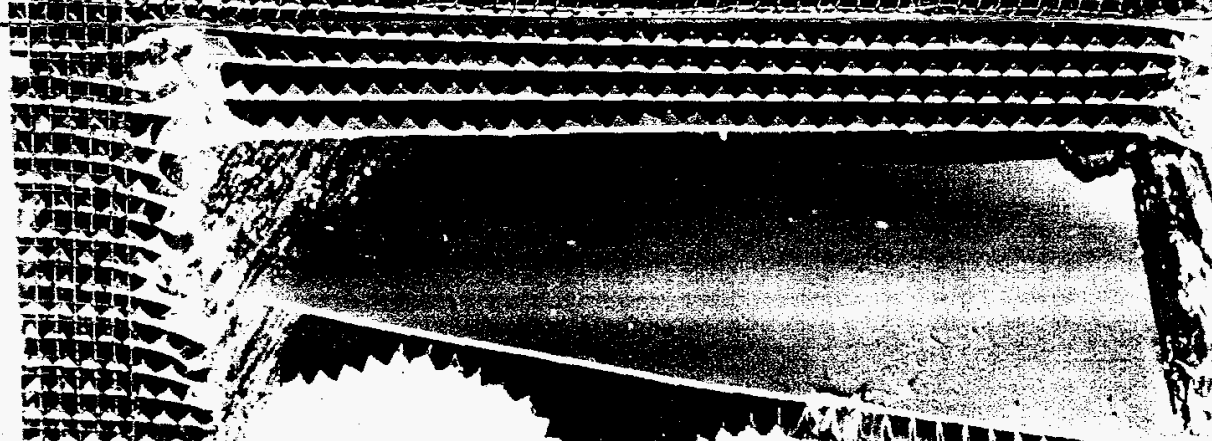

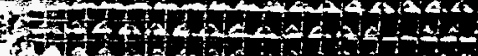

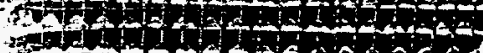

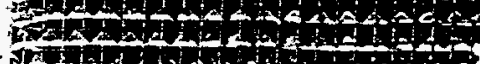

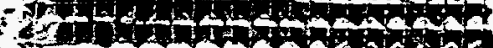

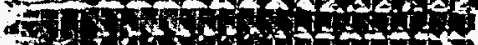

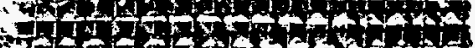

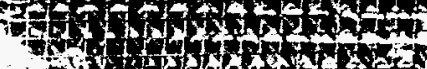

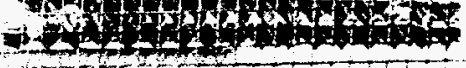

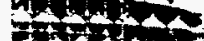

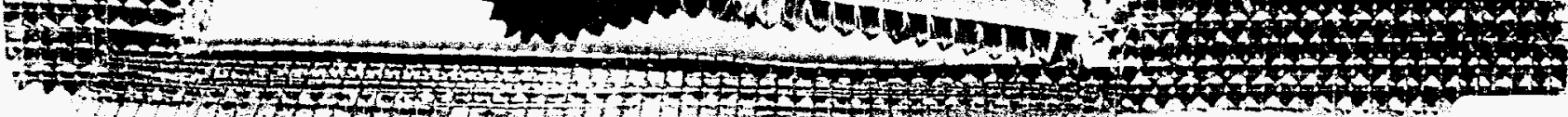

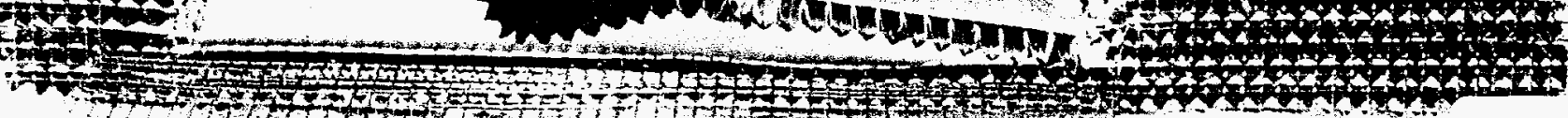

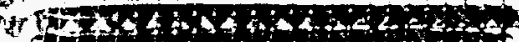

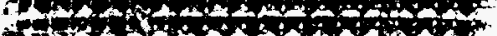

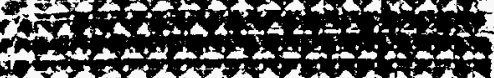

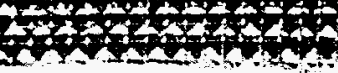

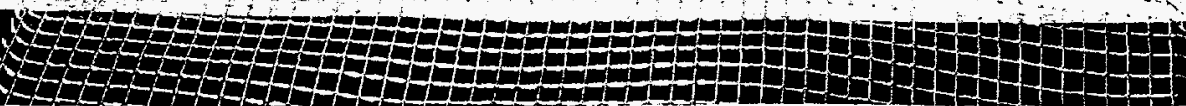




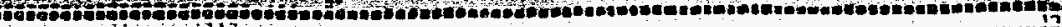

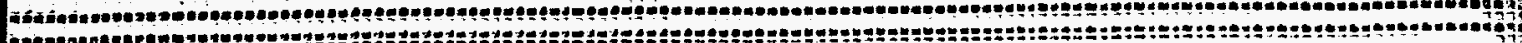
Gecter

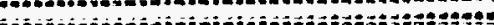
CPA 作

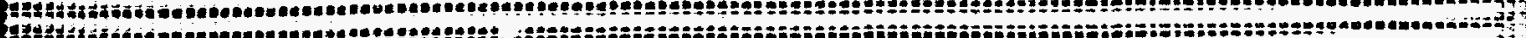

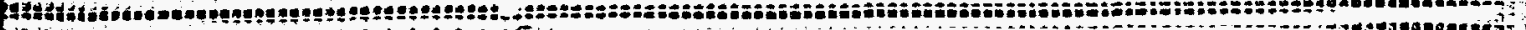

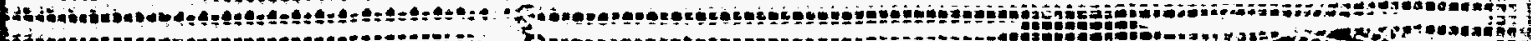
do

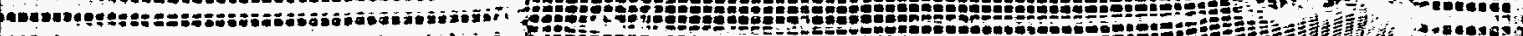

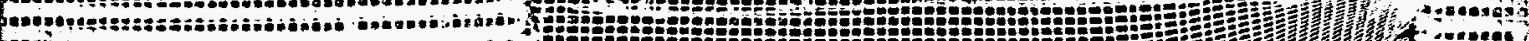

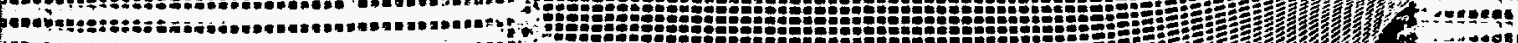
fepege

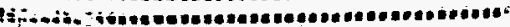

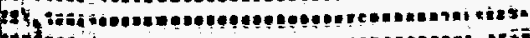

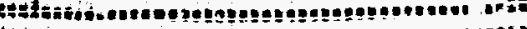

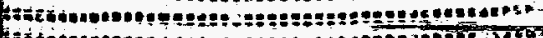

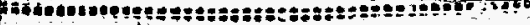

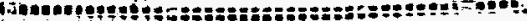

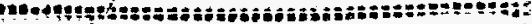

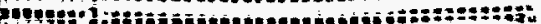

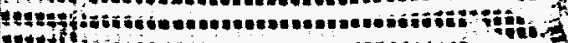

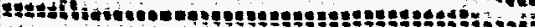
$\$ 7$

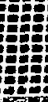

Whọpen Fur Geroved

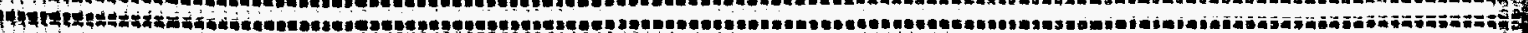
Whot

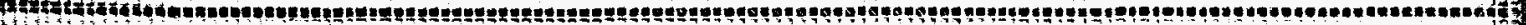

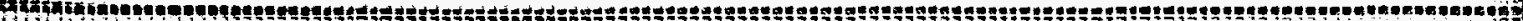

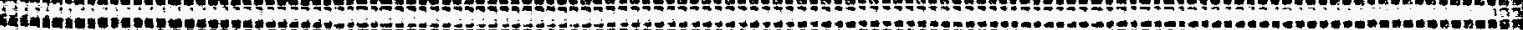

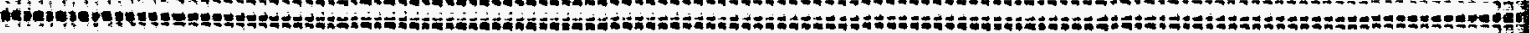

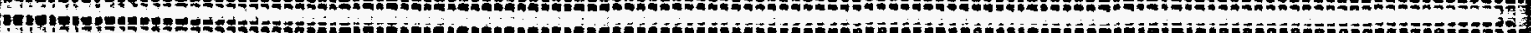
494 (1)

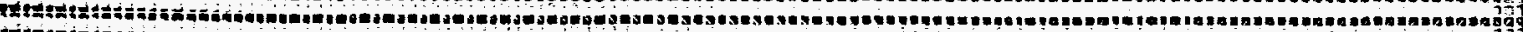

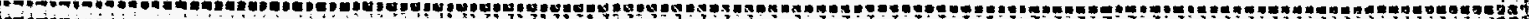

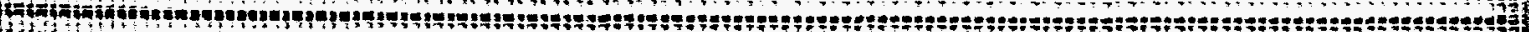

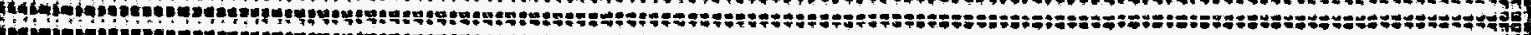

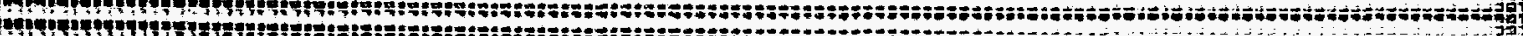

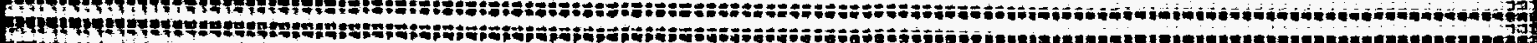
Ply

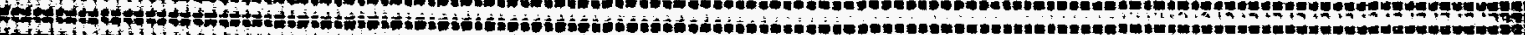
20

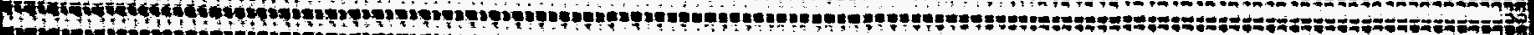

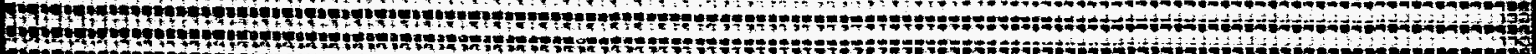

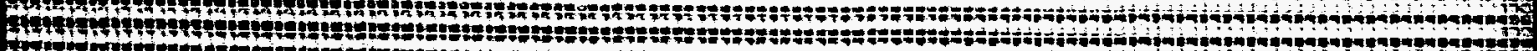

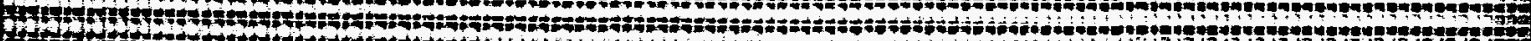

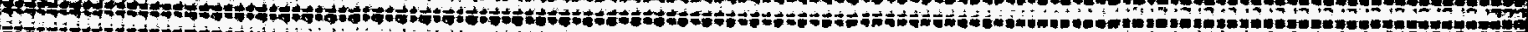

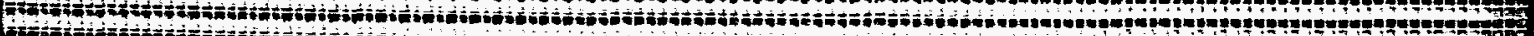
A9

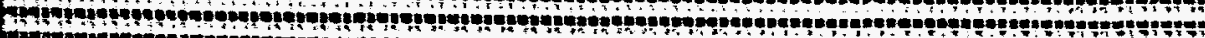
L a

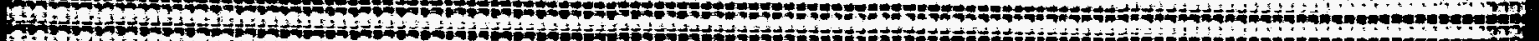

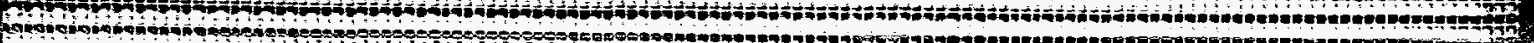

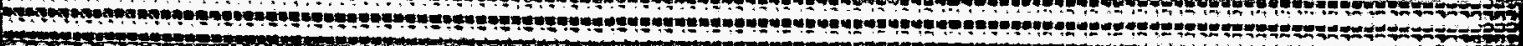

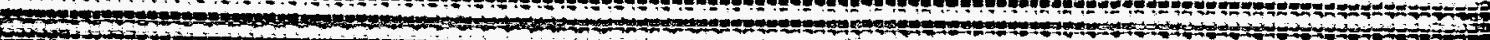

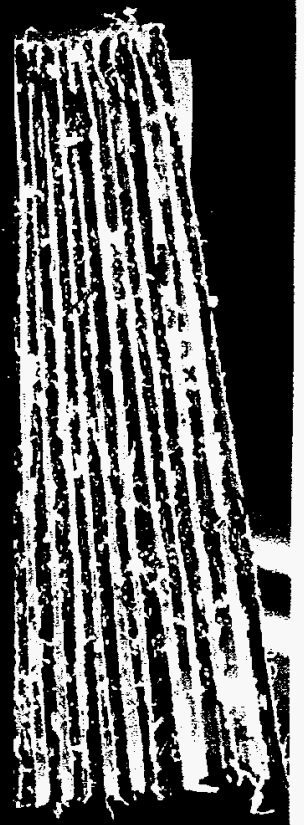




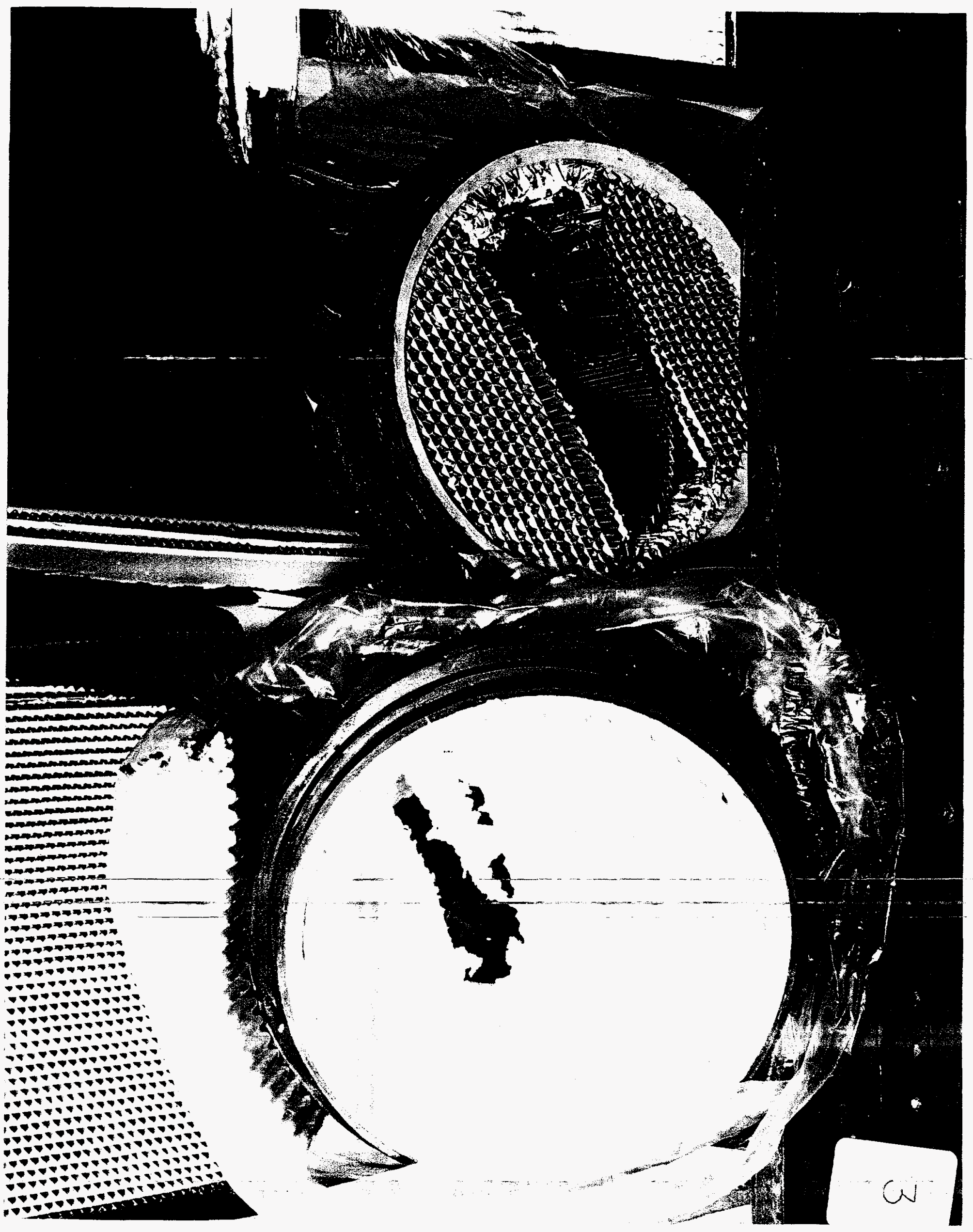



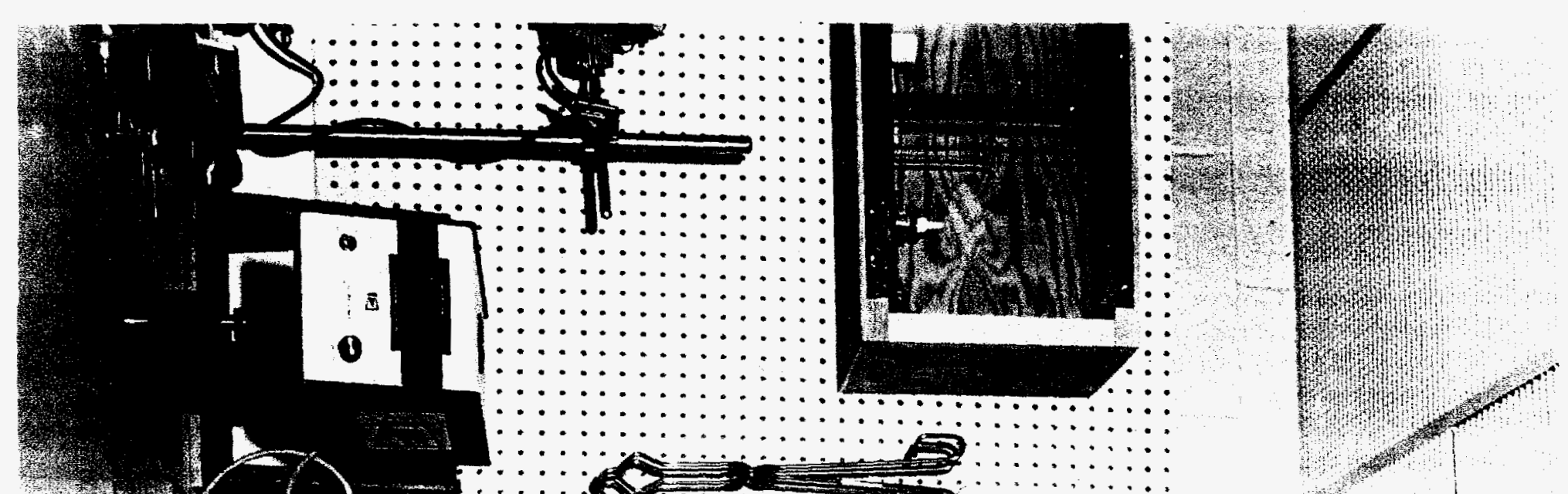

1. $120+8$

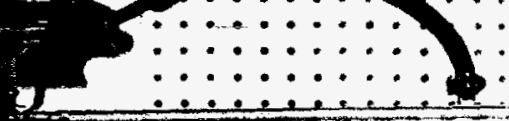

-

$20.0 .0 .0 .4=$

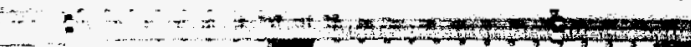

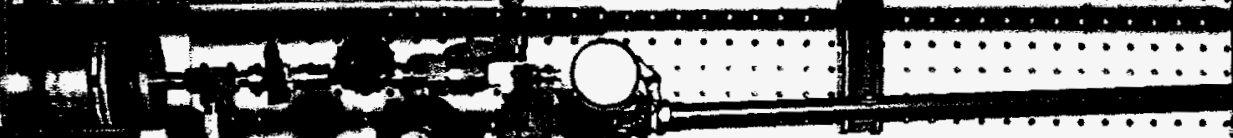

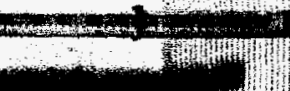

Itwinthy

W

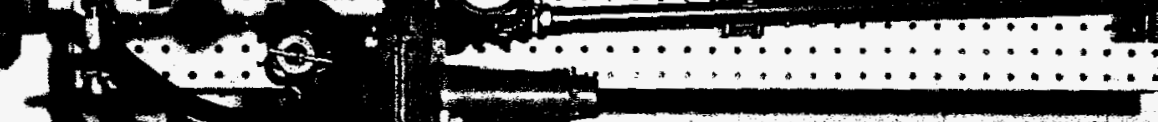

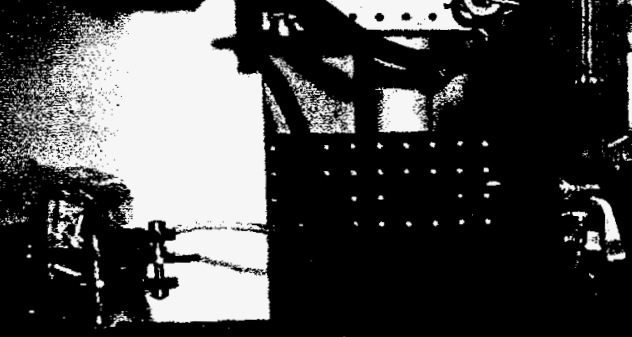

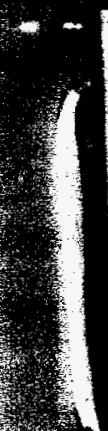

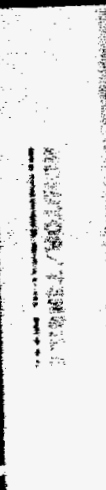

(1)

E.

topts

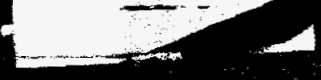

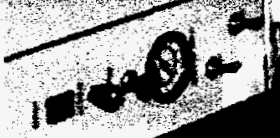

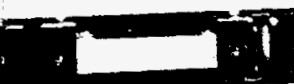

㞼

$$
\text { . }
$$
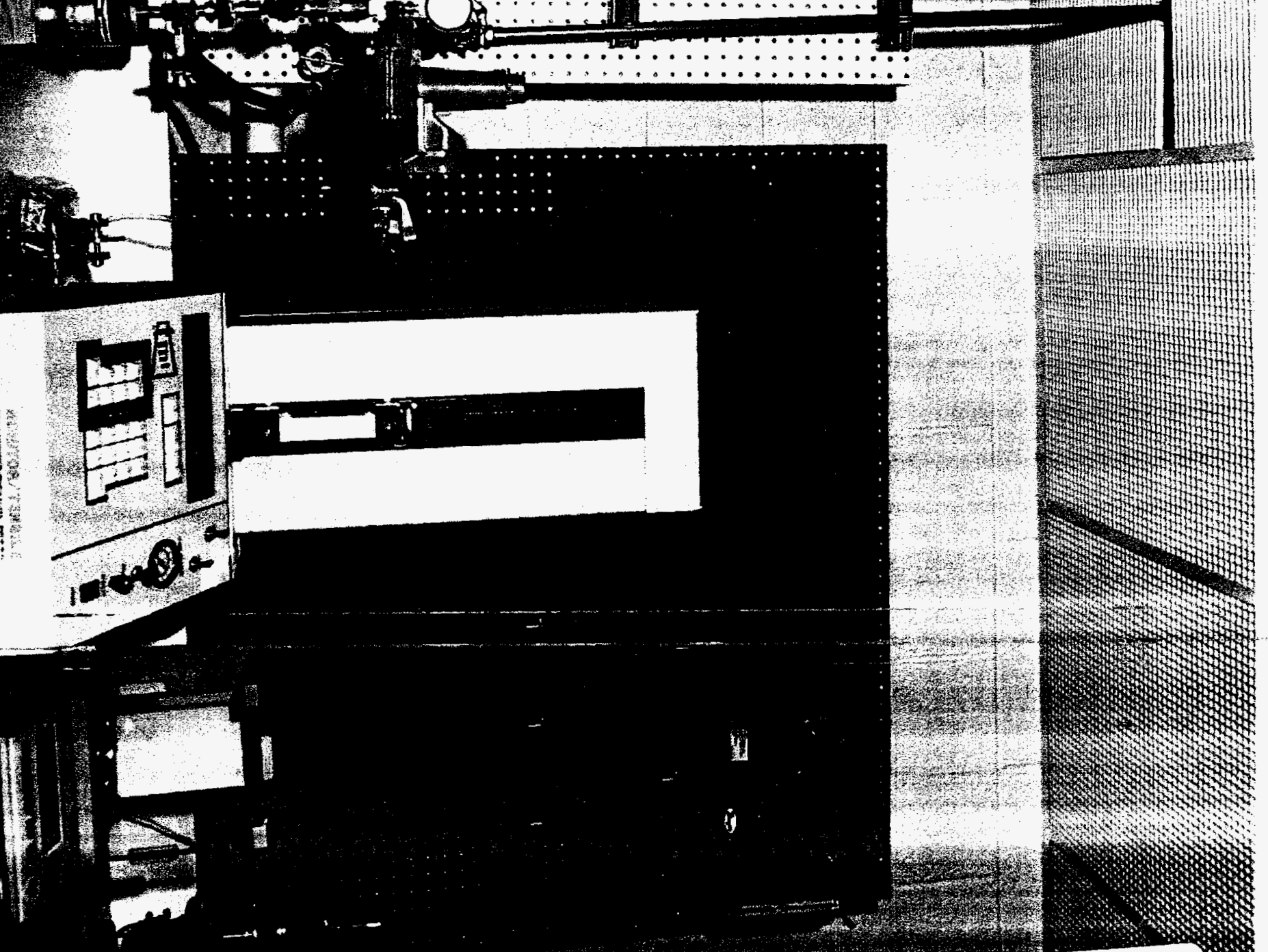


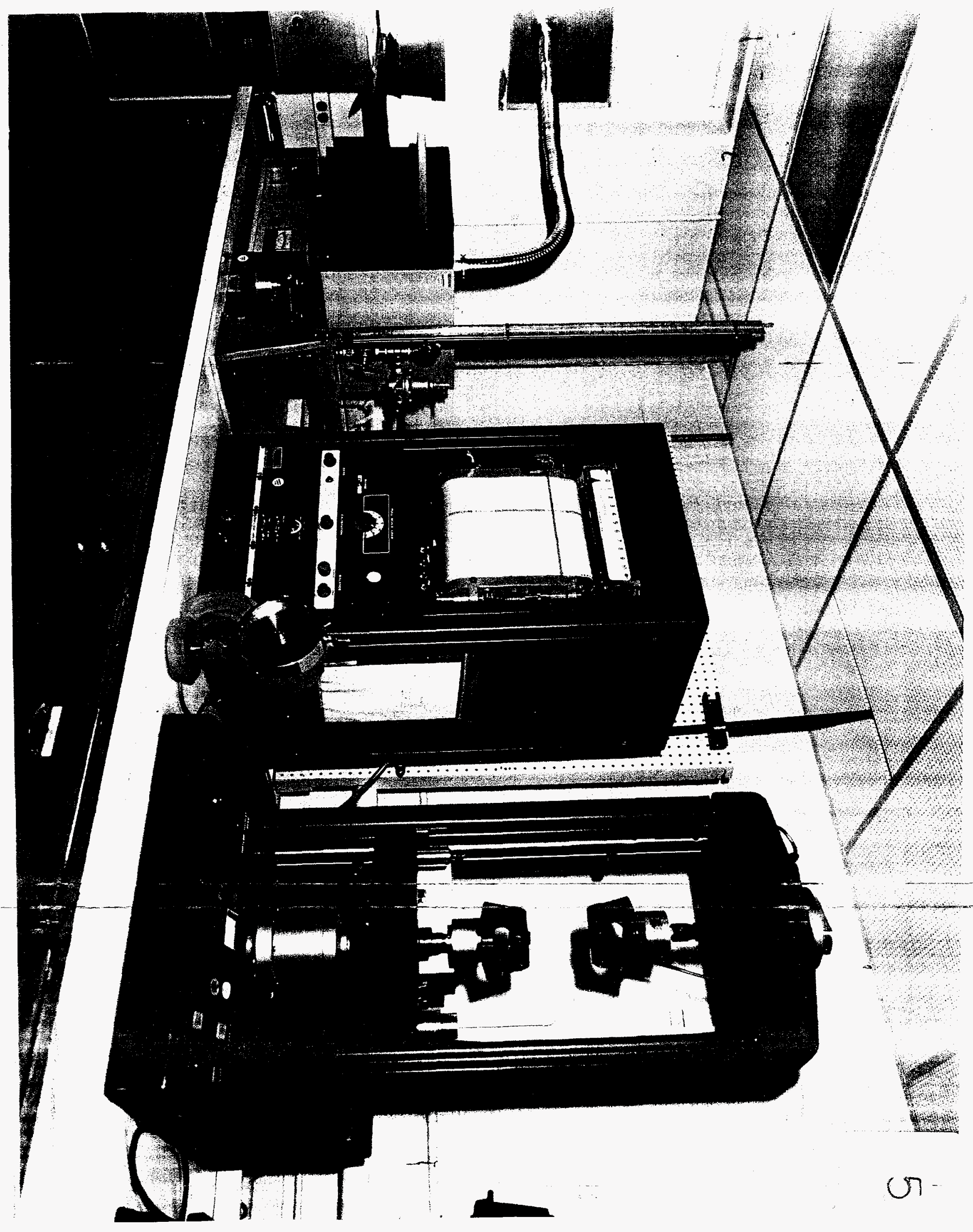




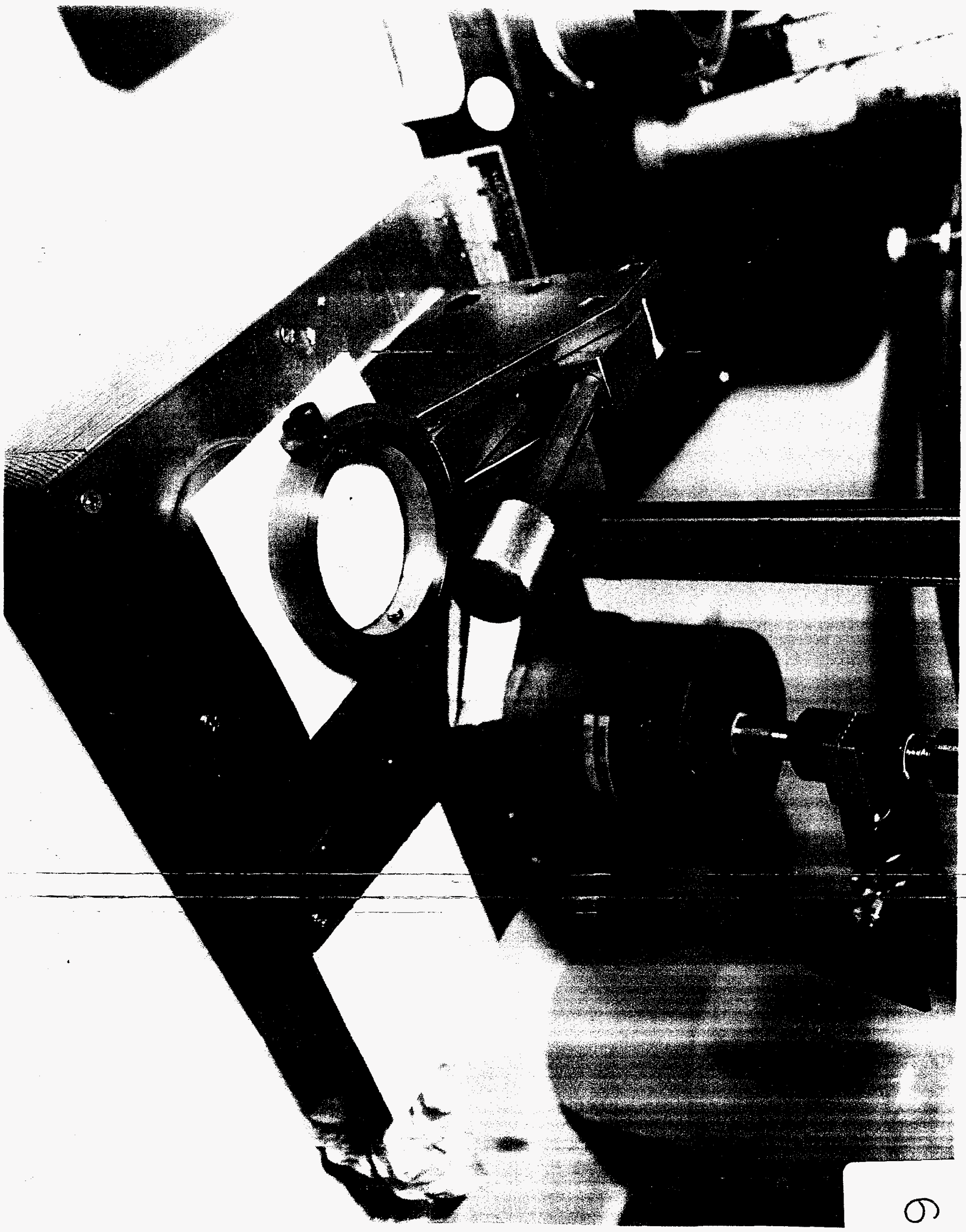




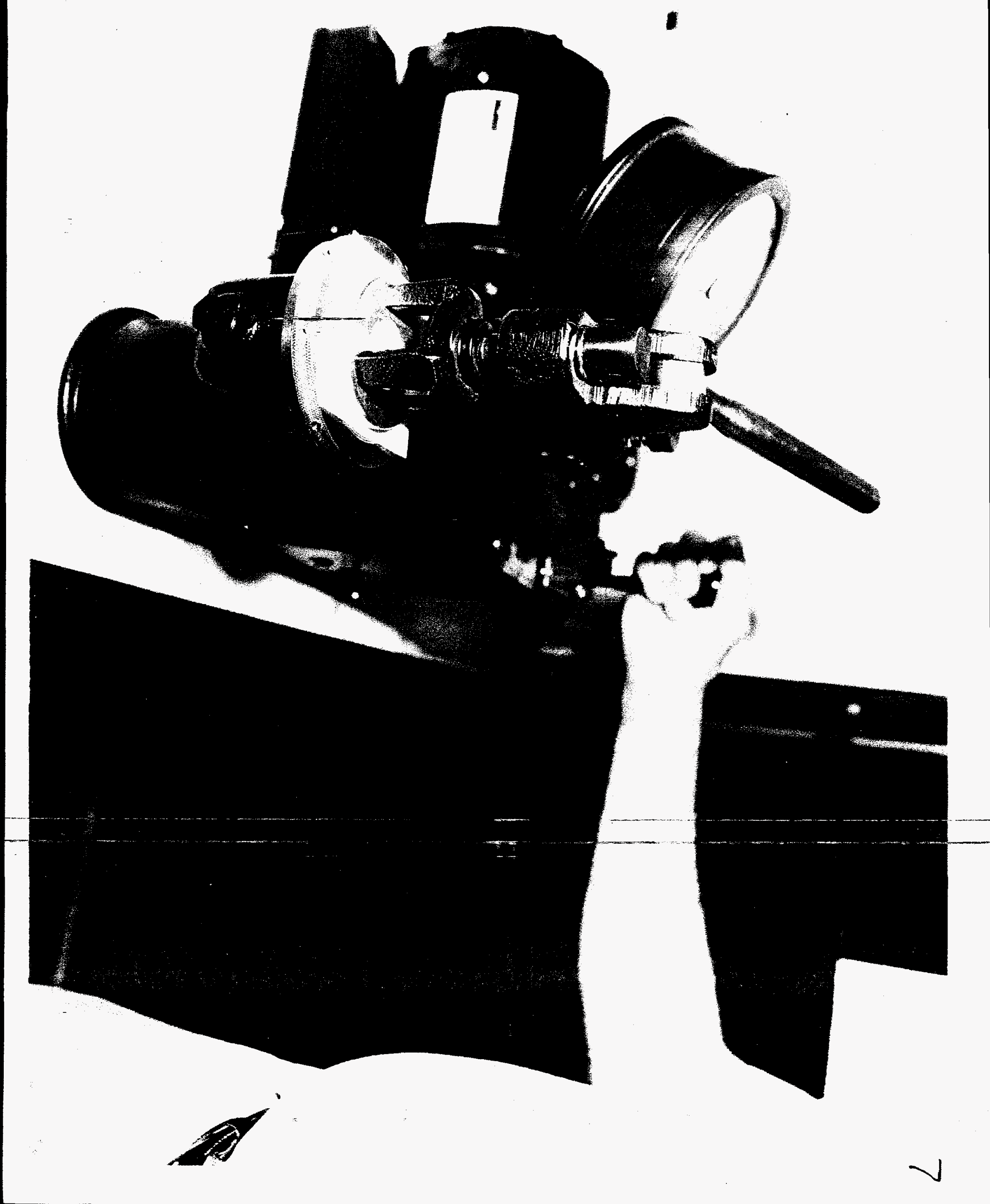




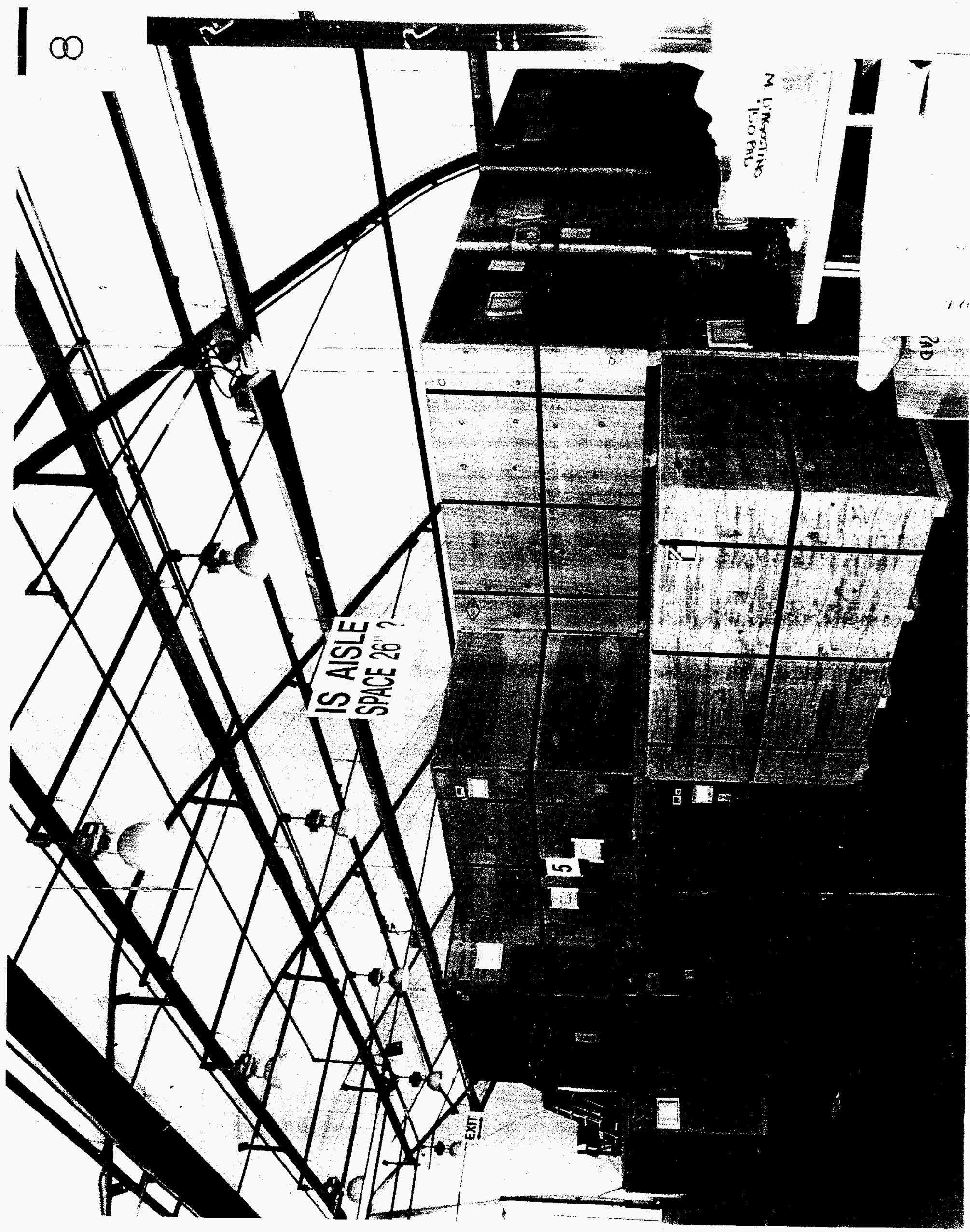




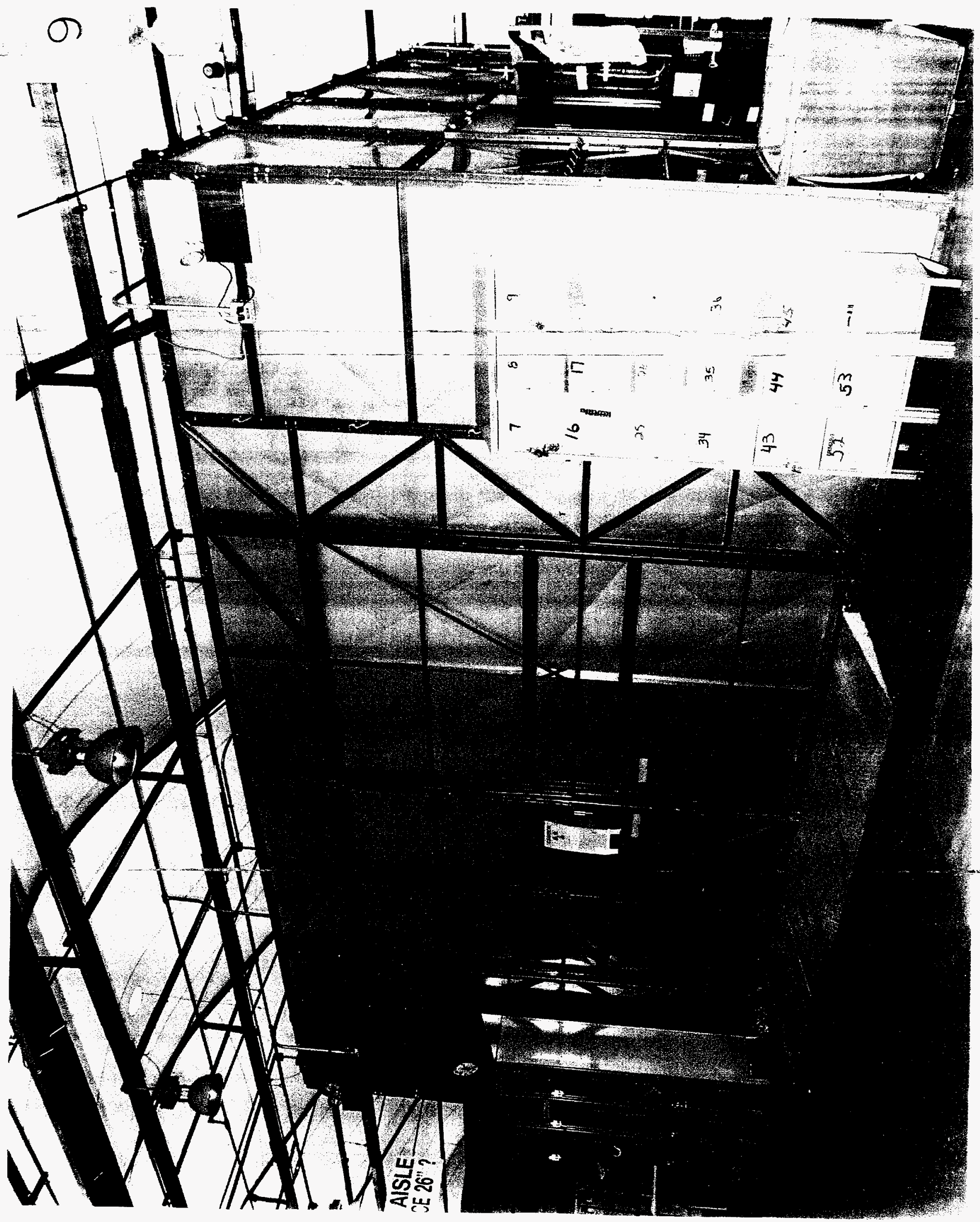




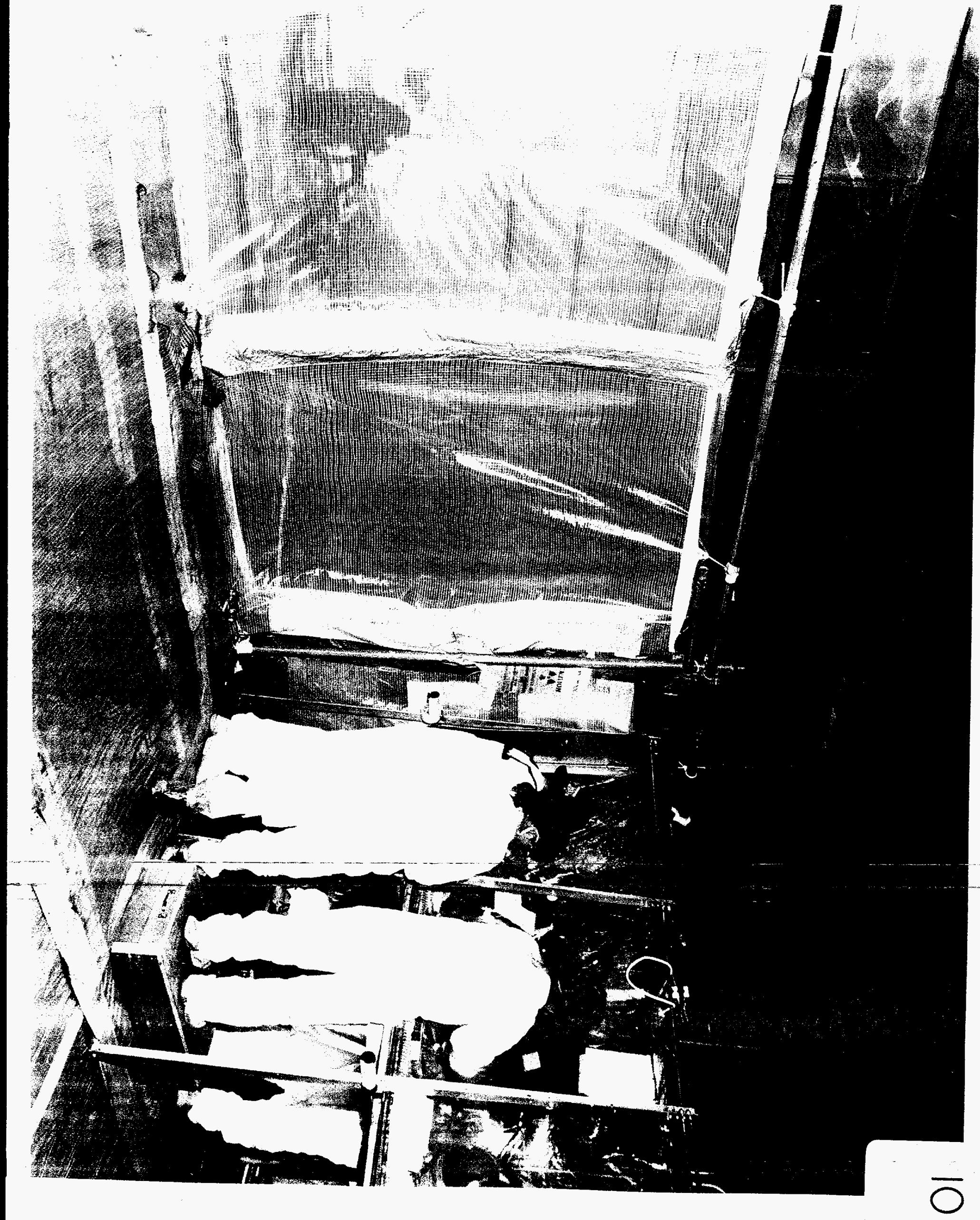




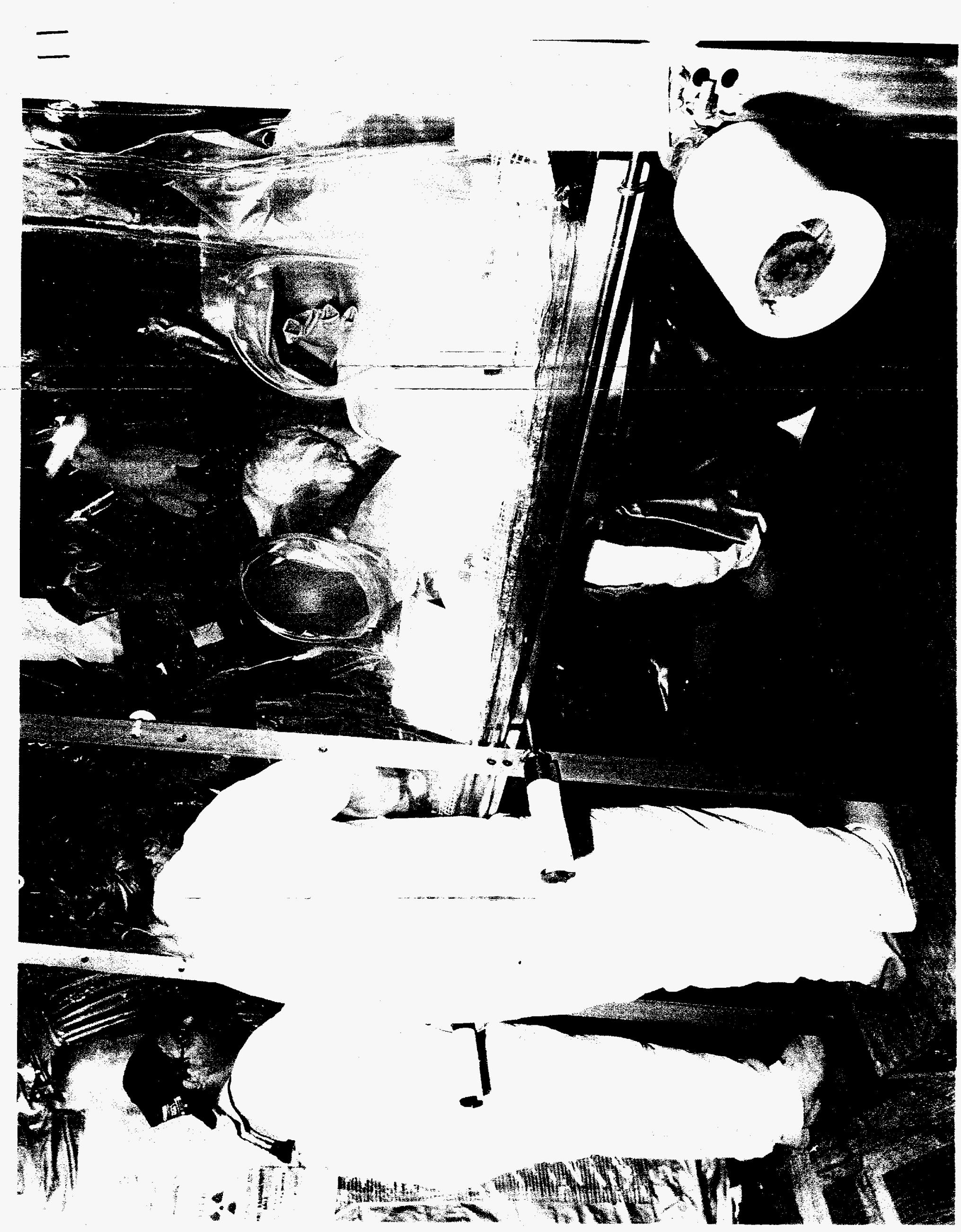




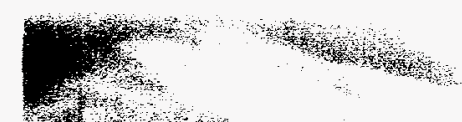
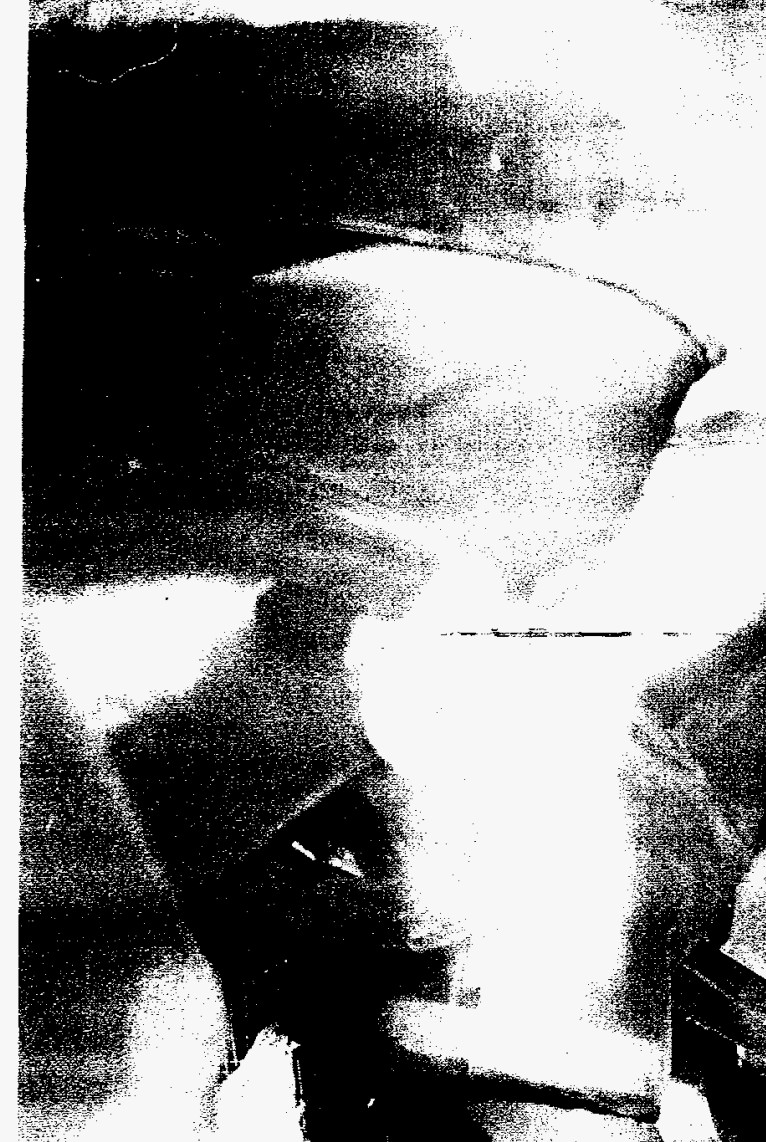

?

7.

3.

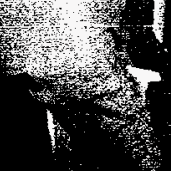

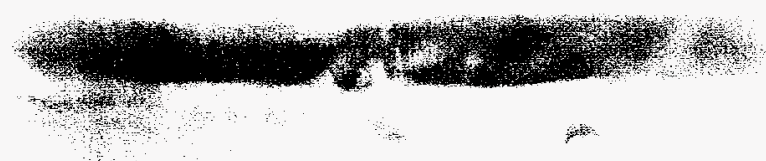

s) 1 का

Hat

\section{b}

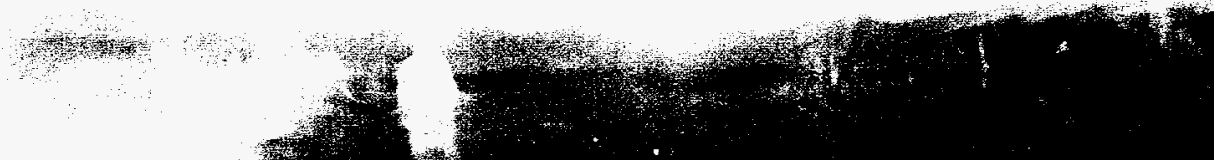
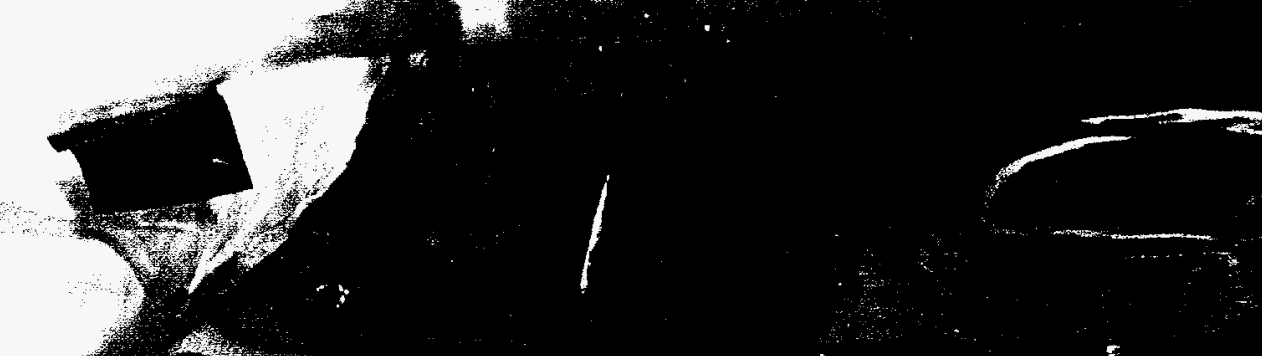

,

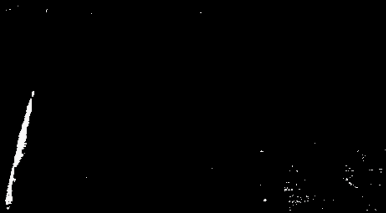

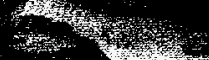

$=$
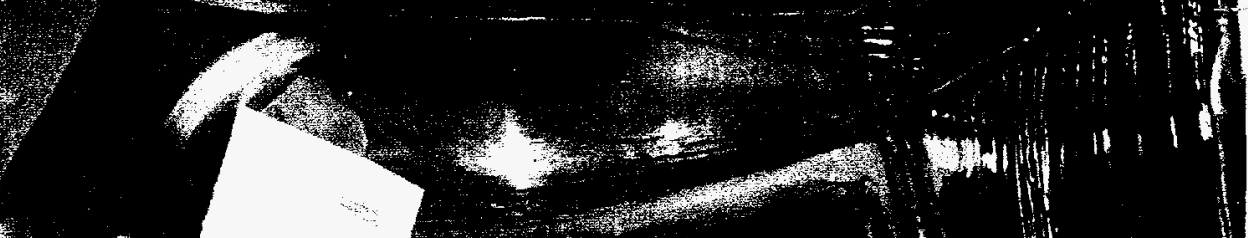

$4 x^{2}+x^{2}$

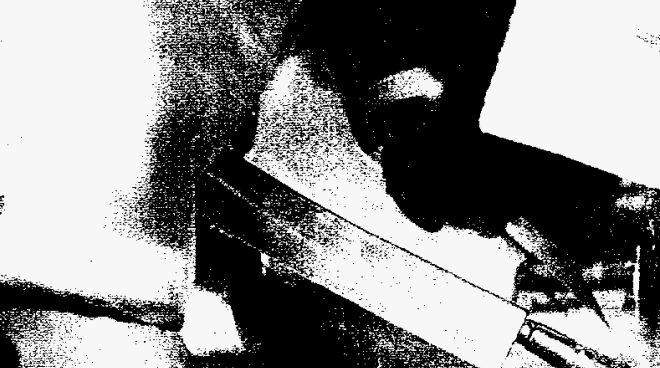

4)
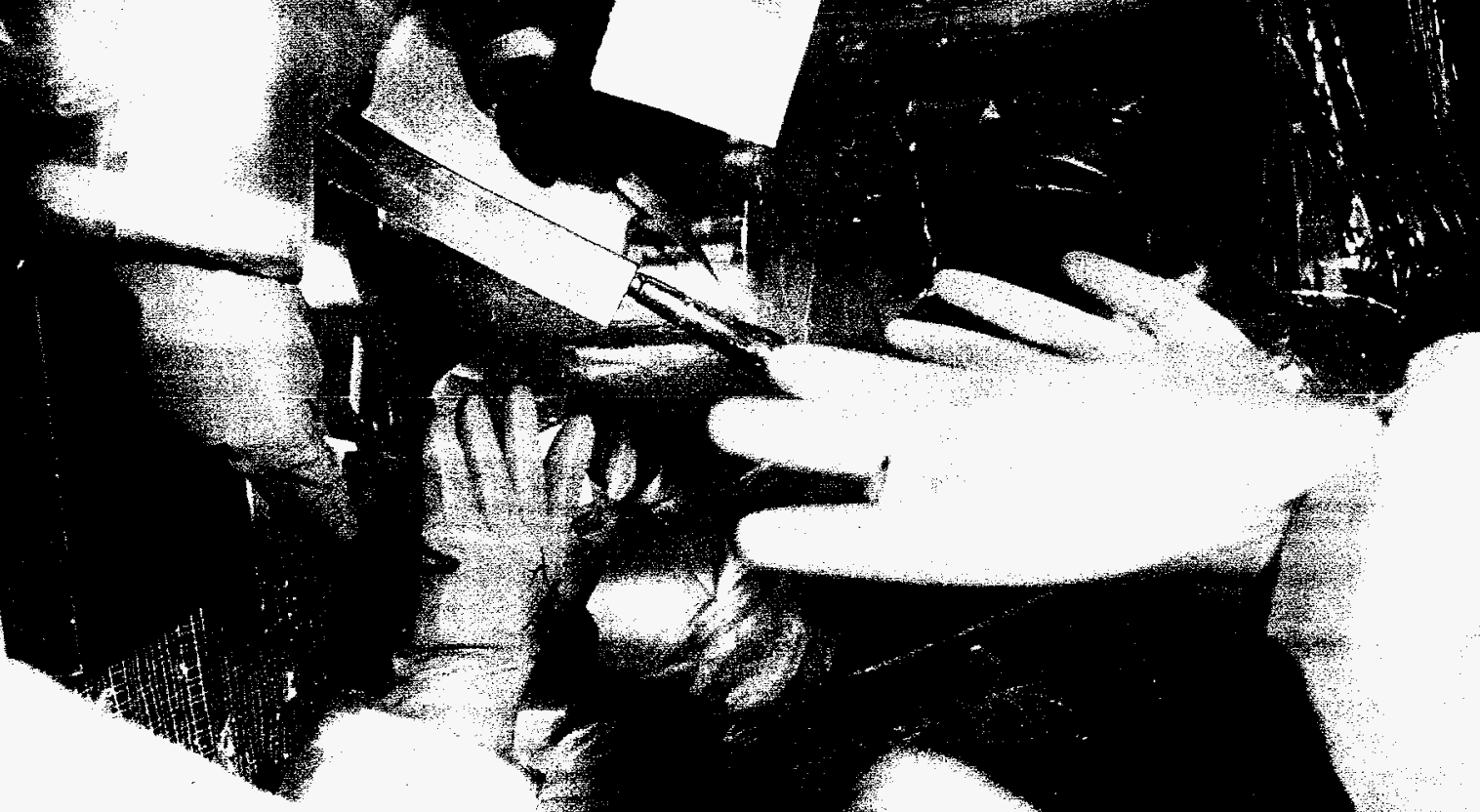


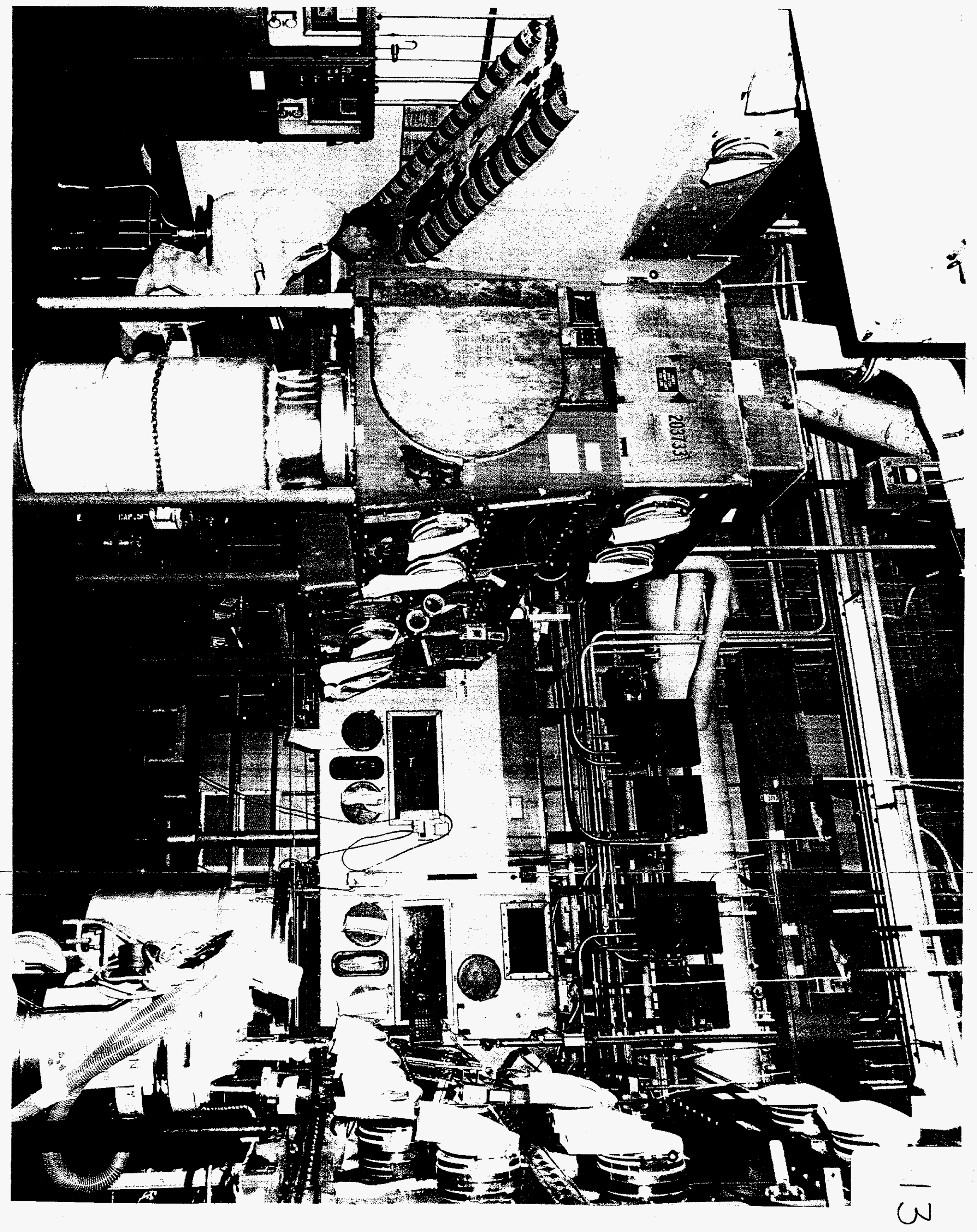




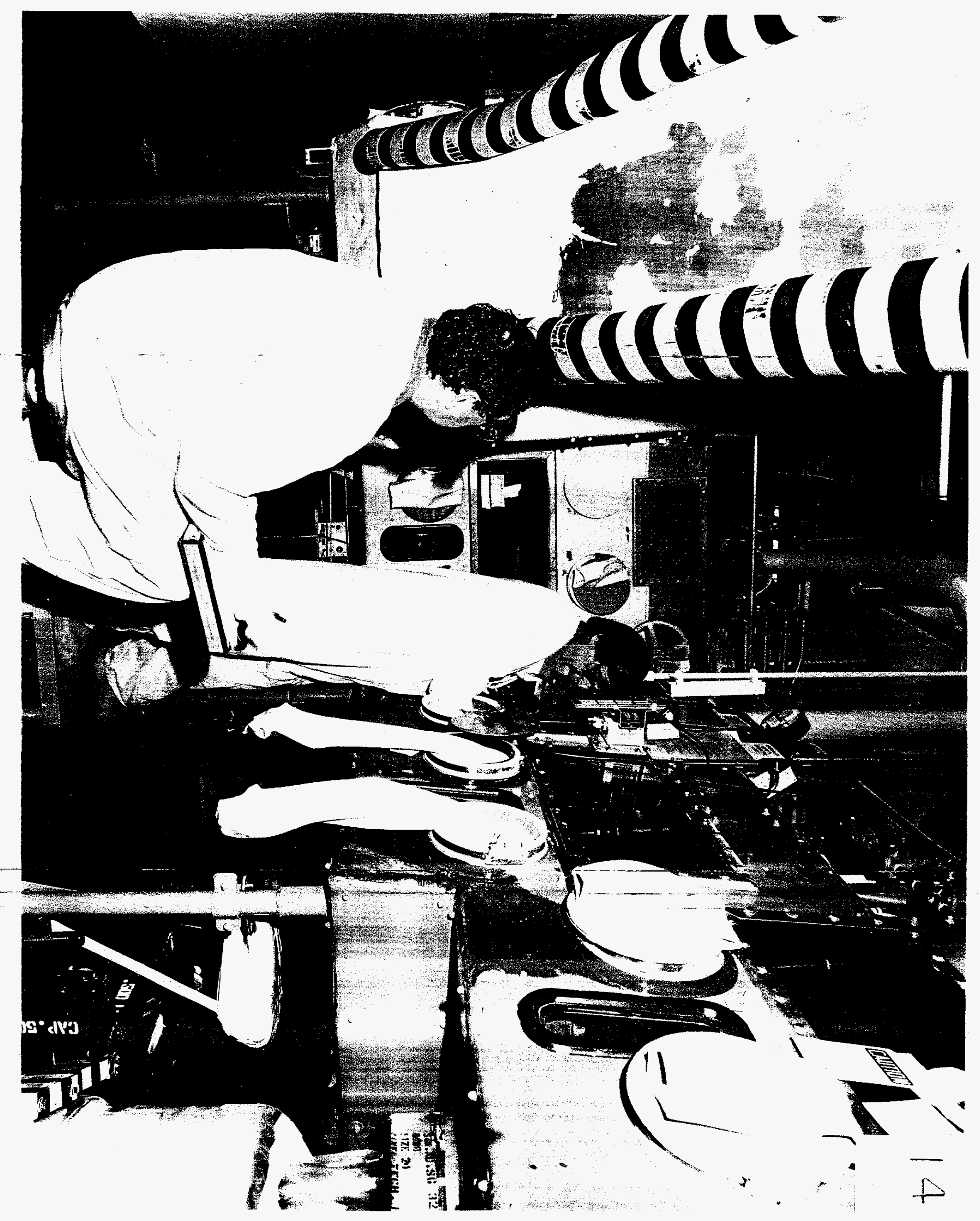




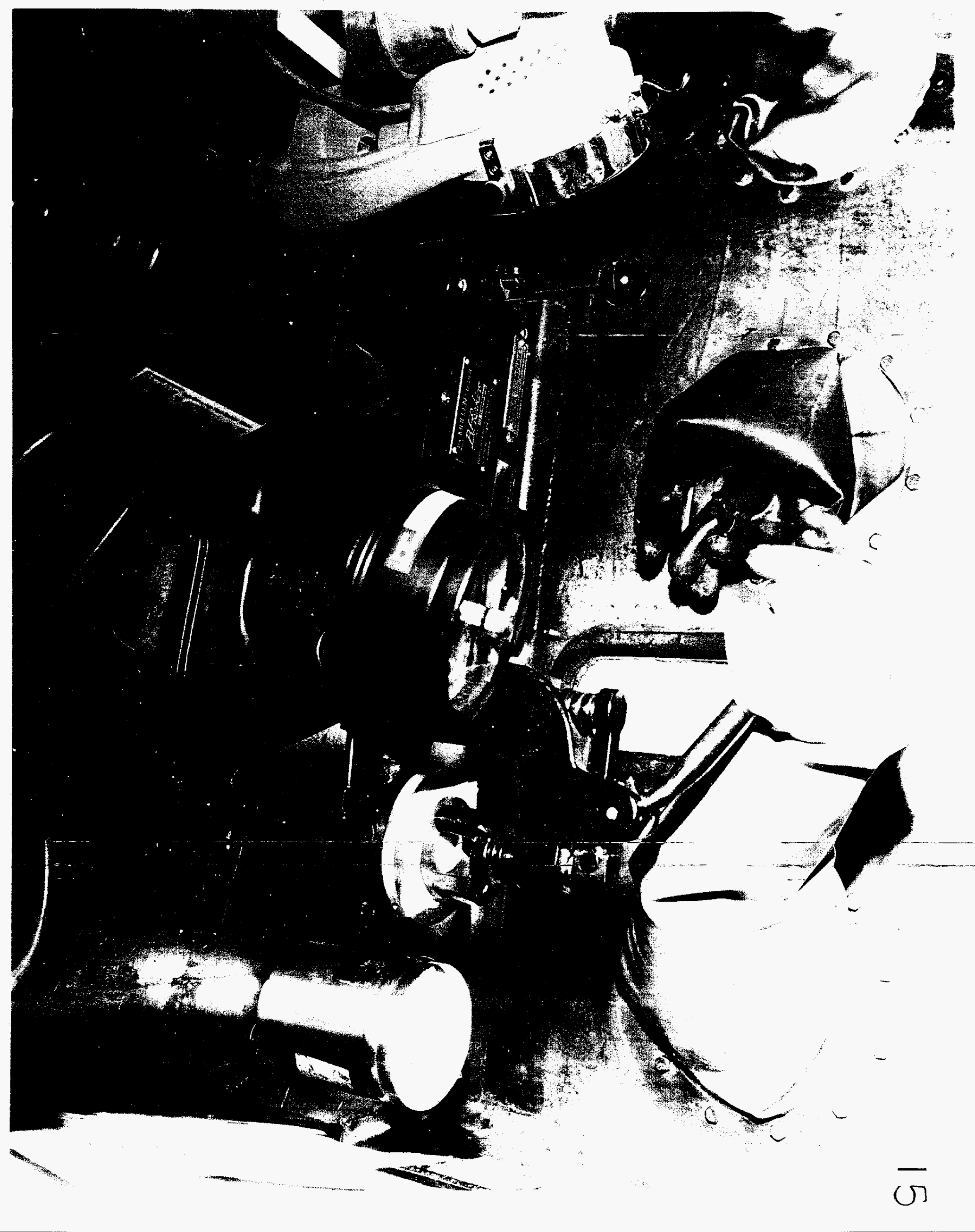




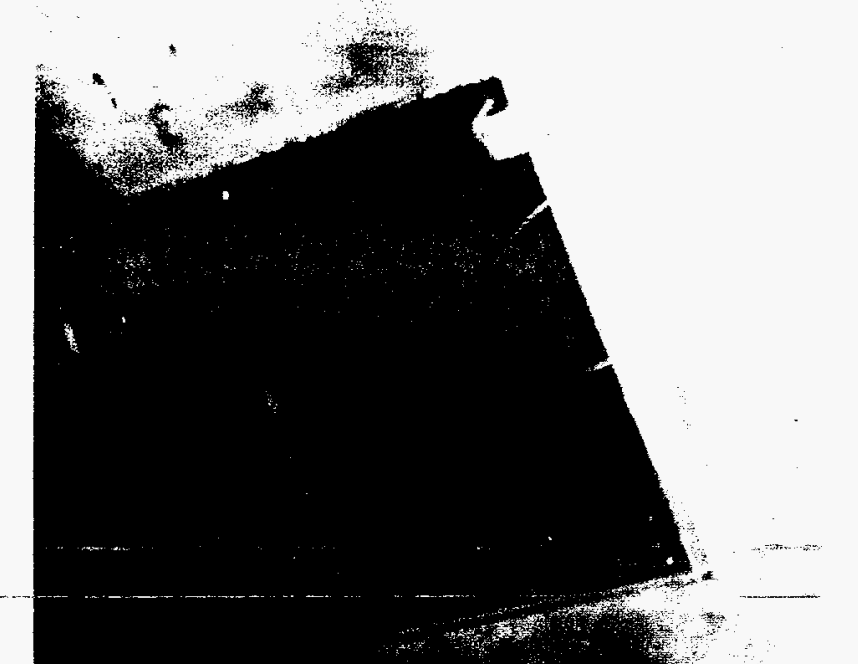

,
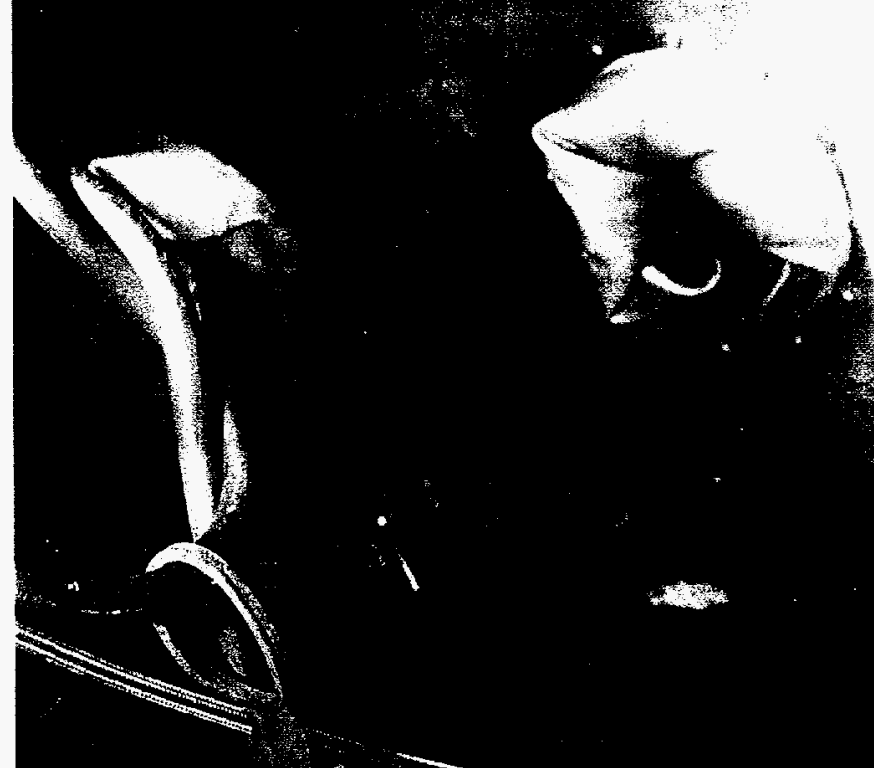


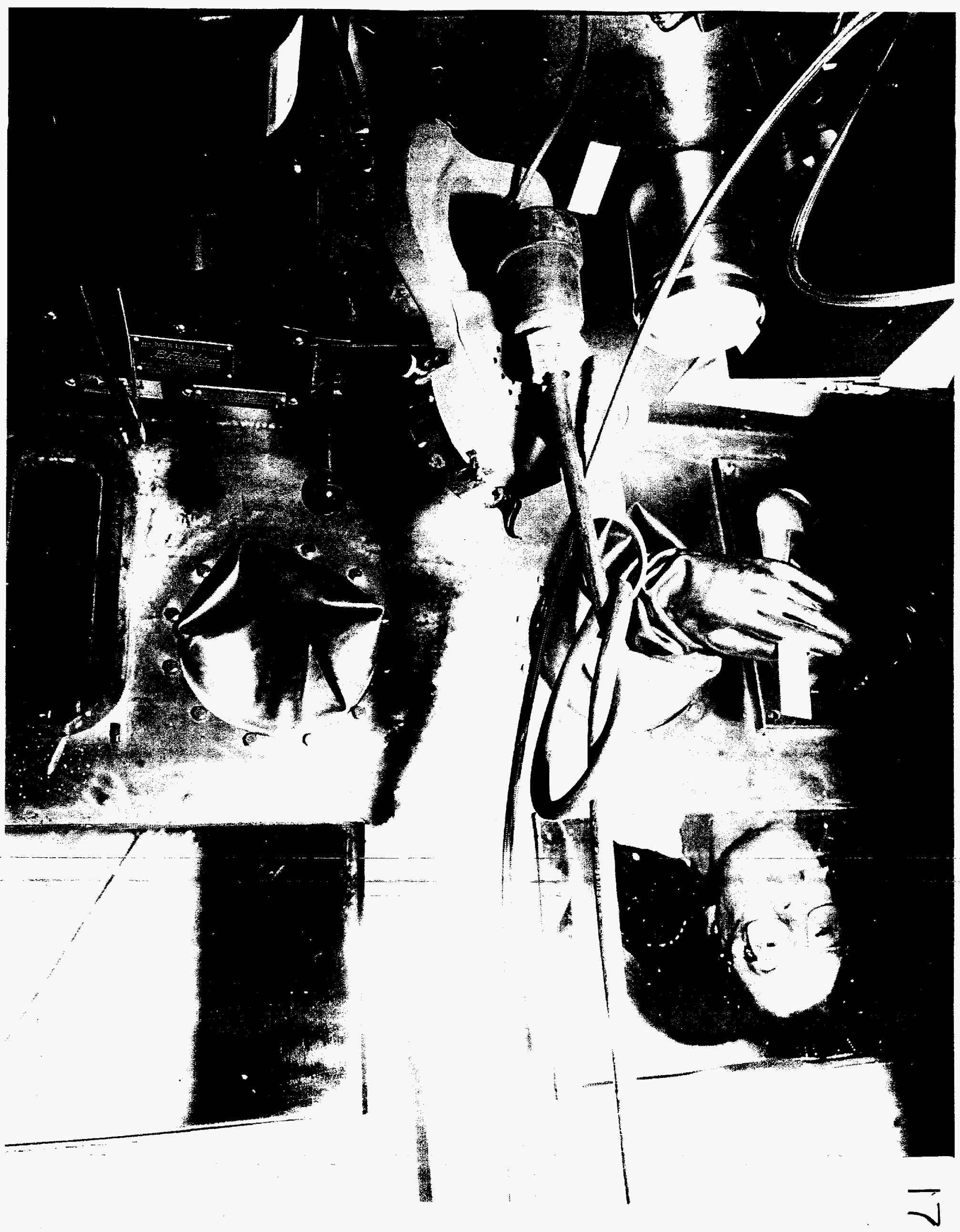



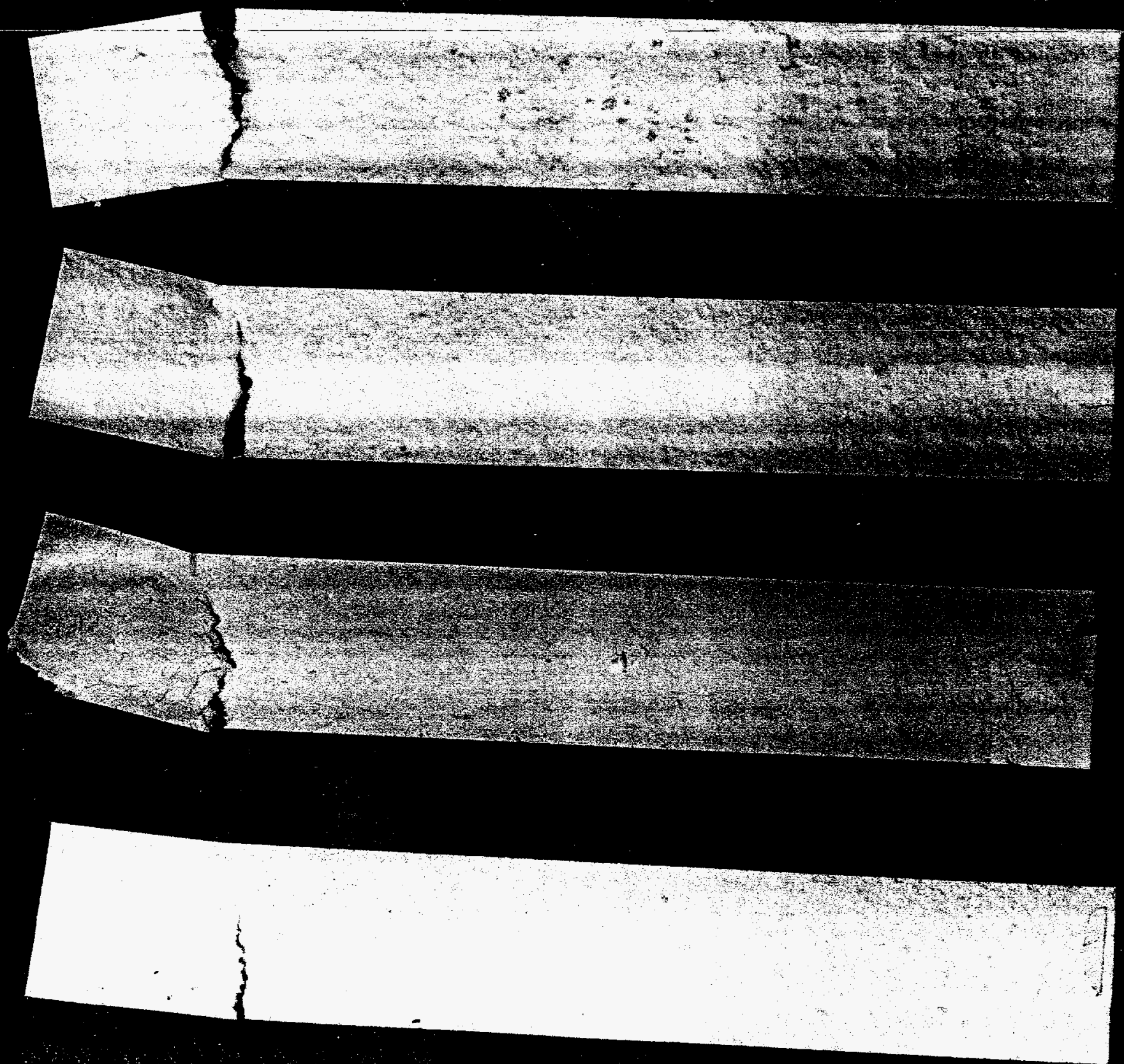

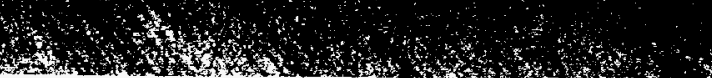



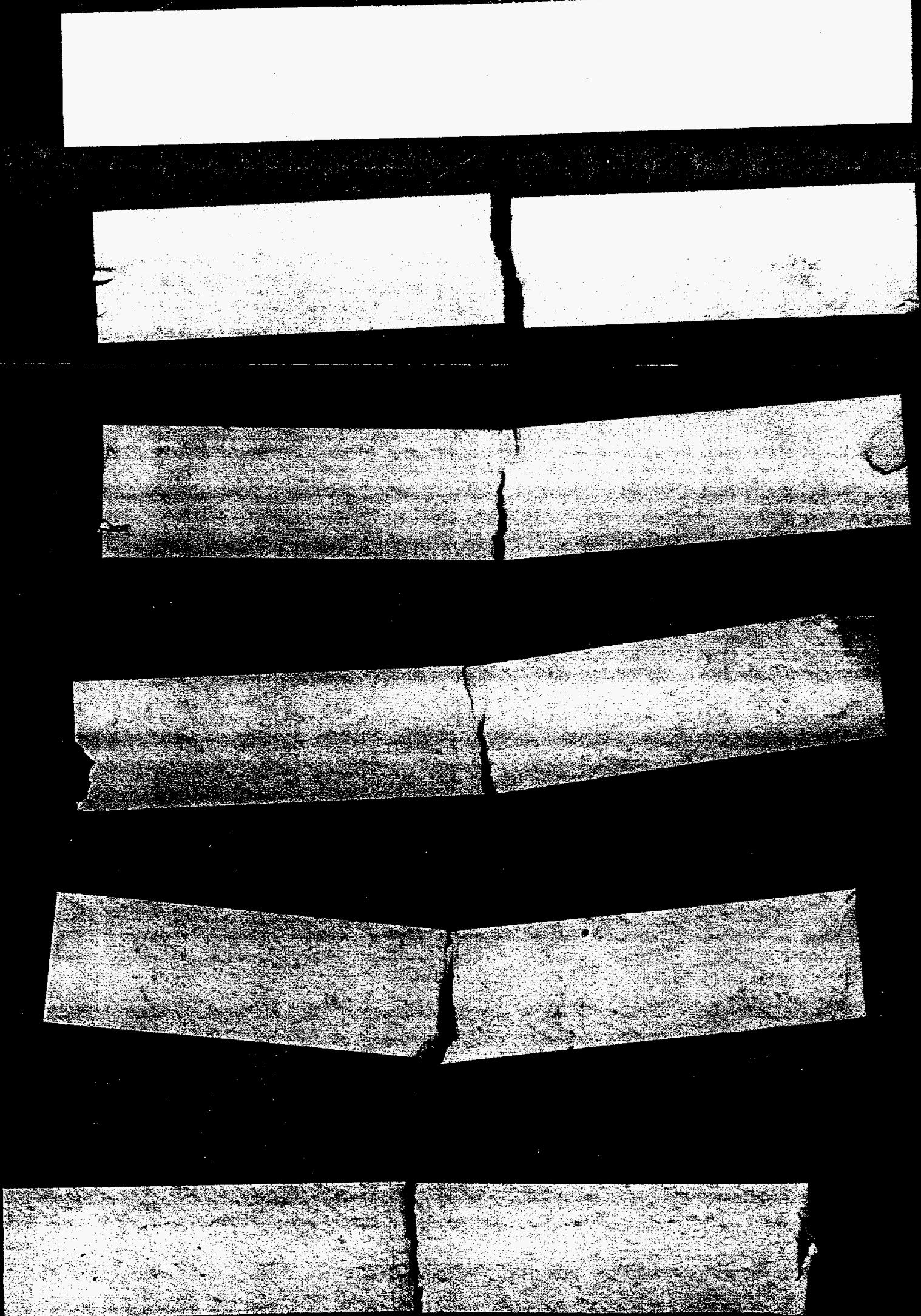

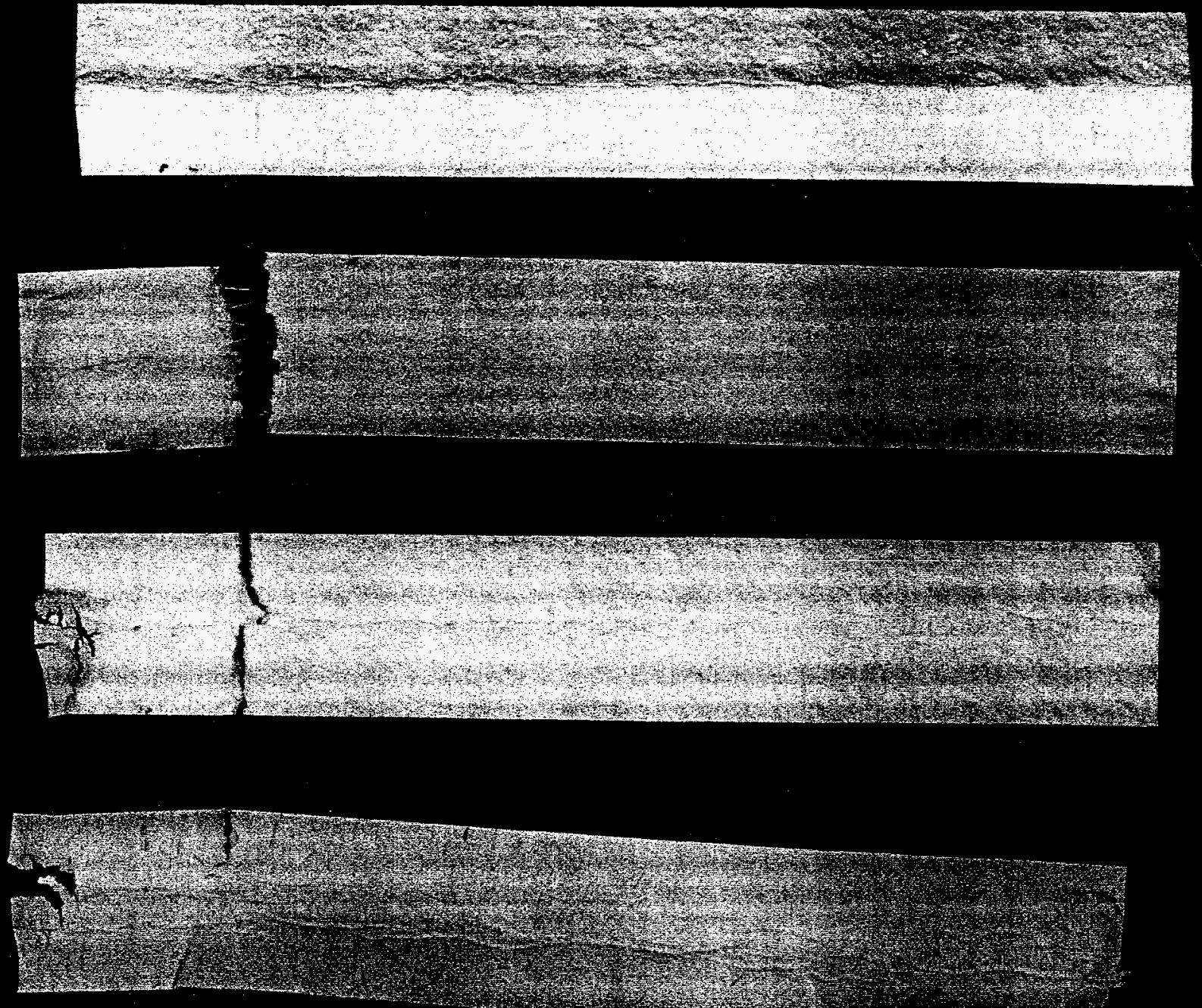

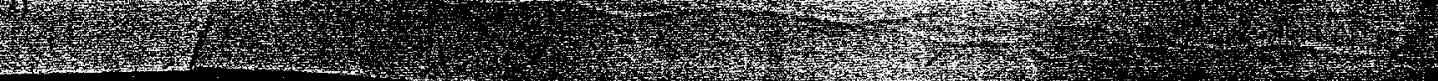

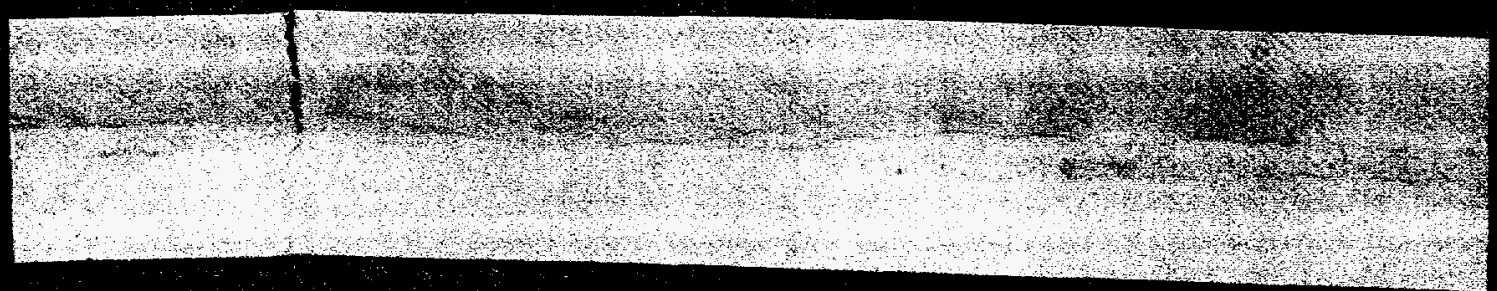



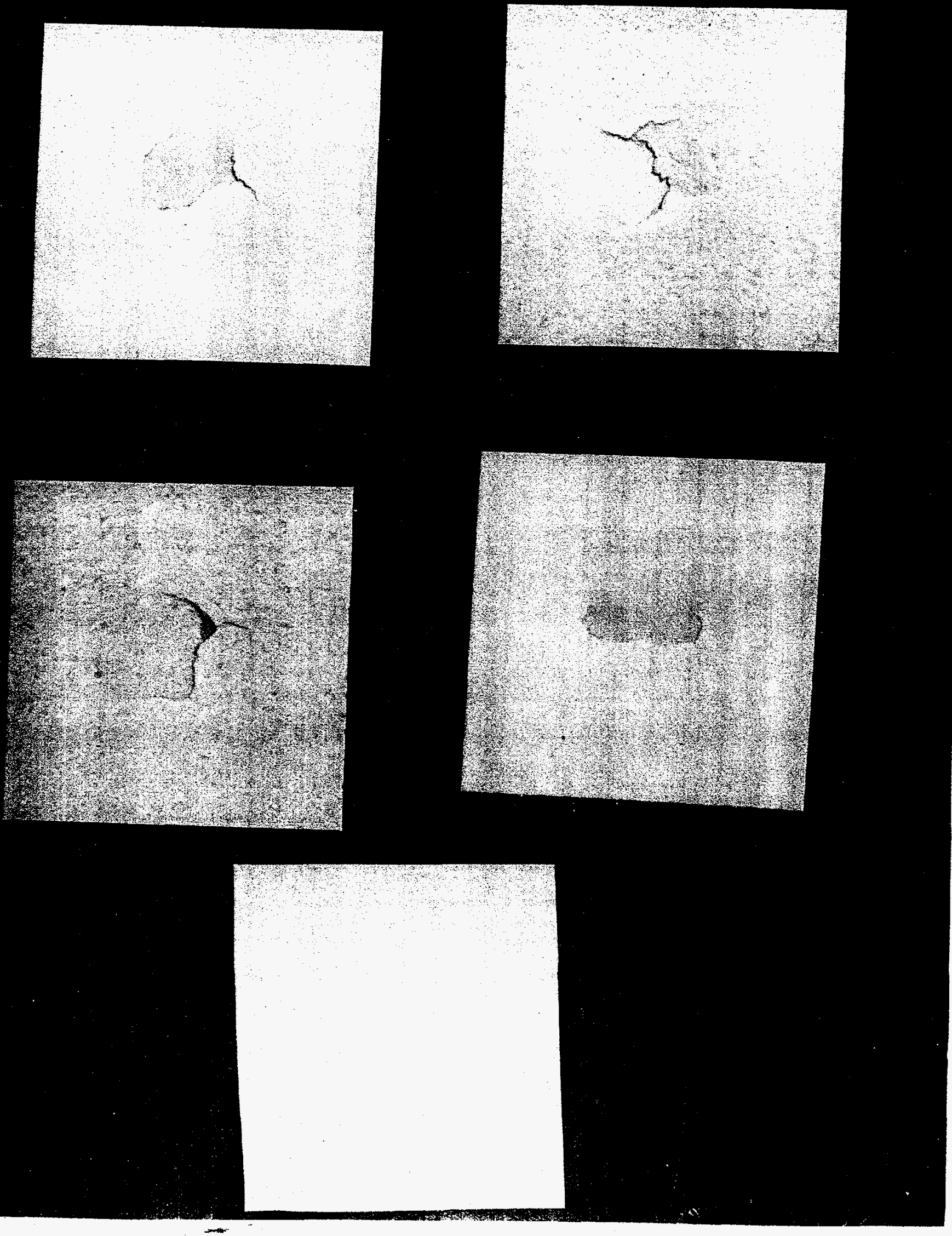

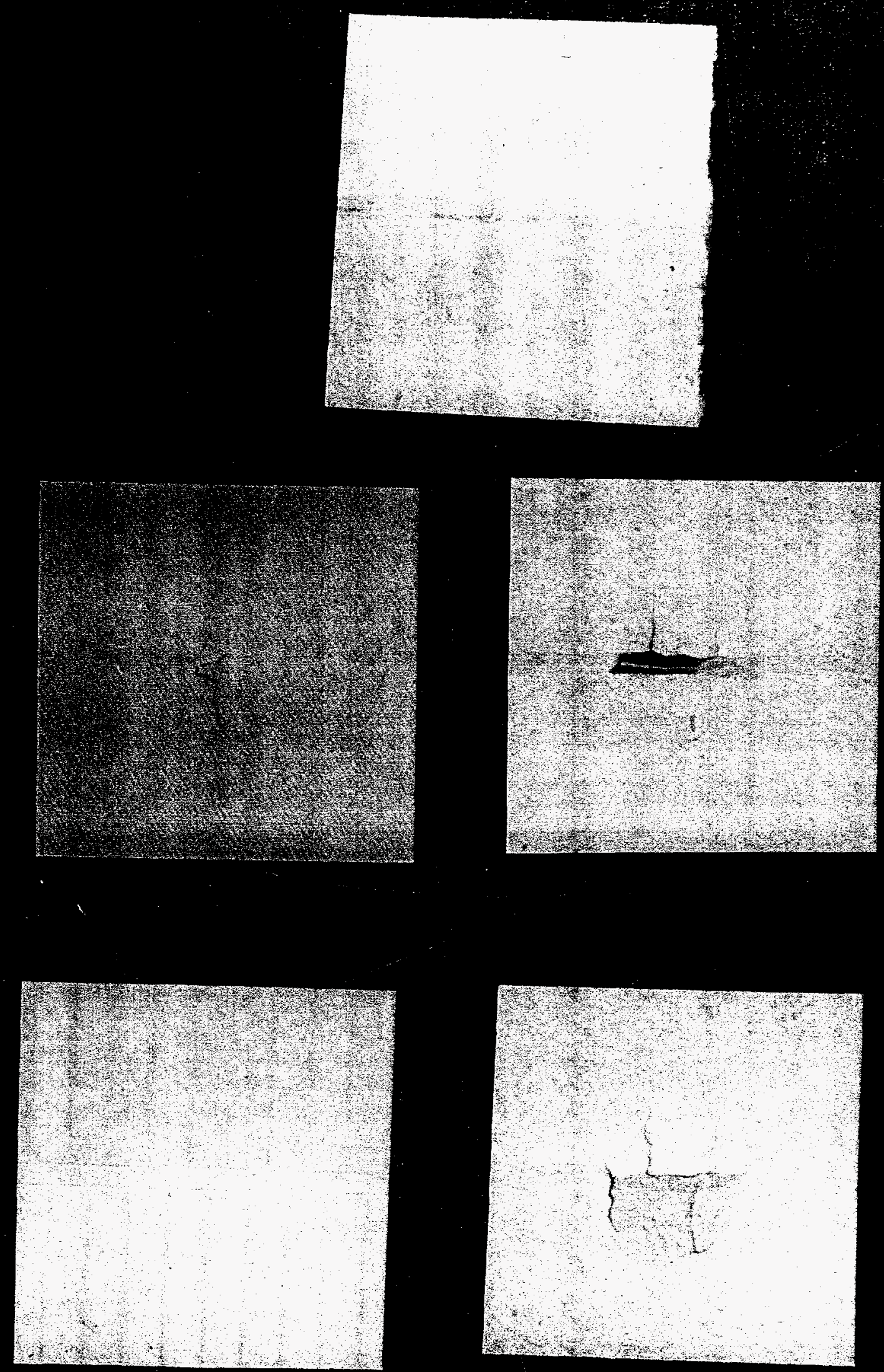

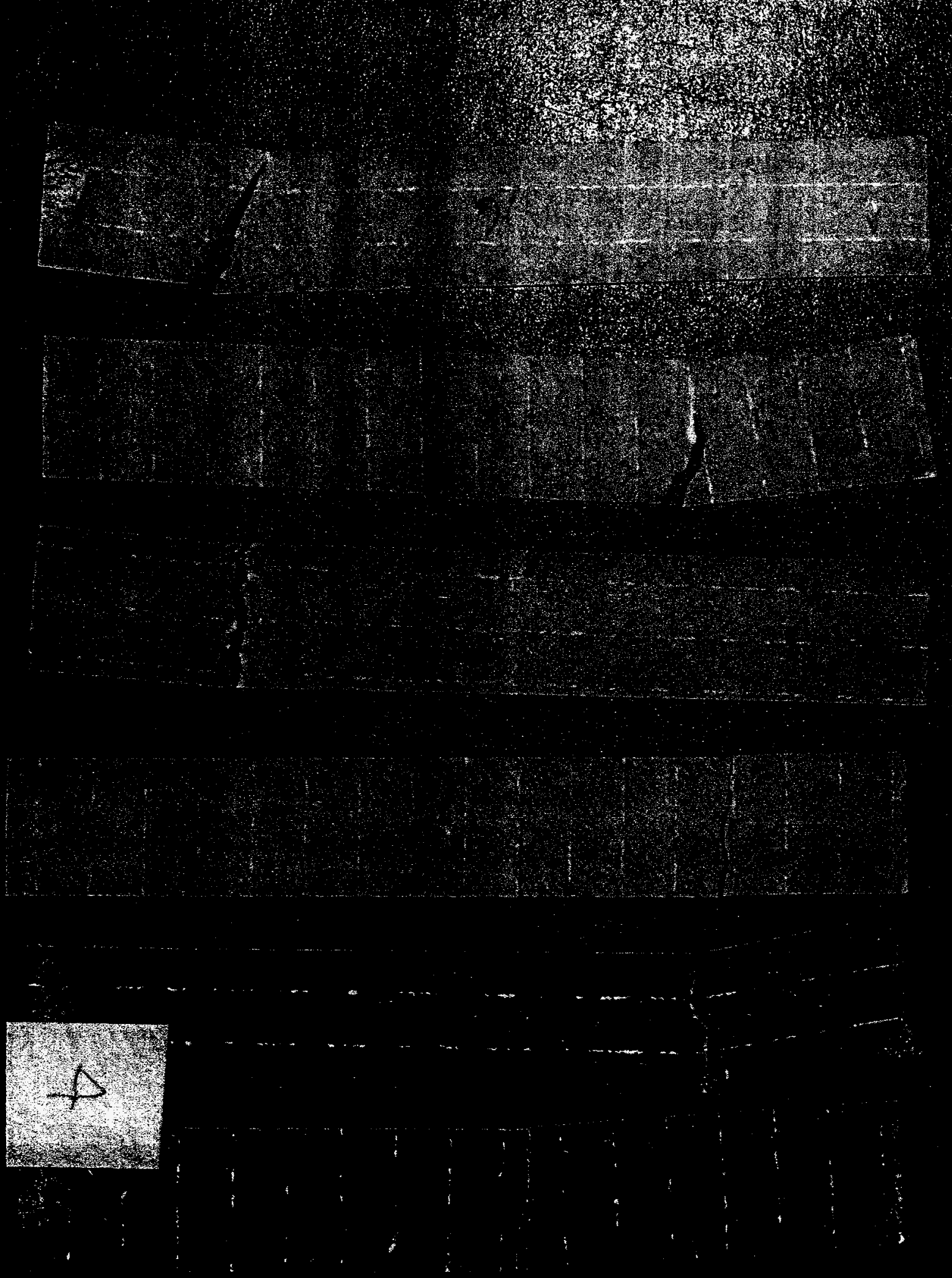


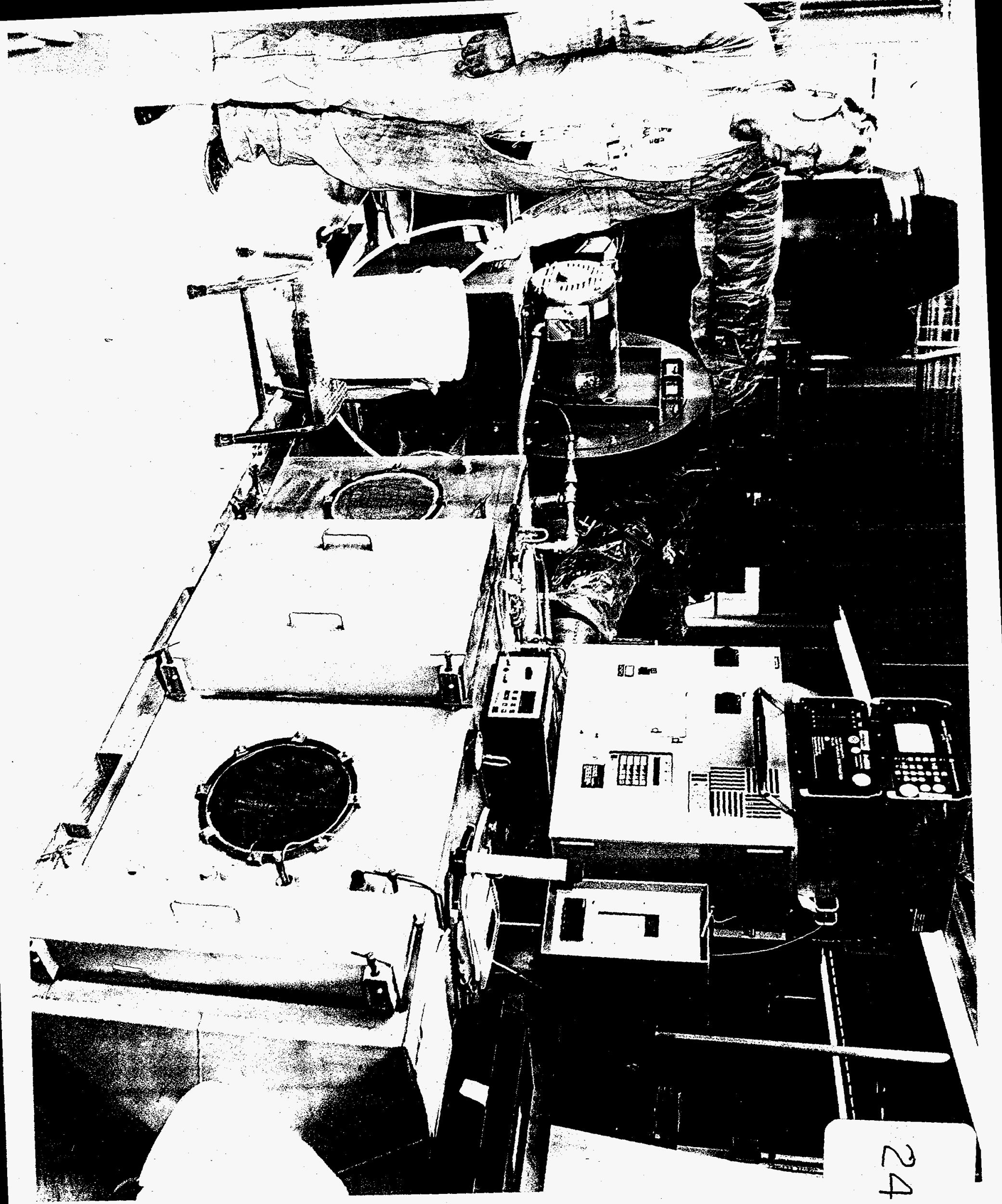




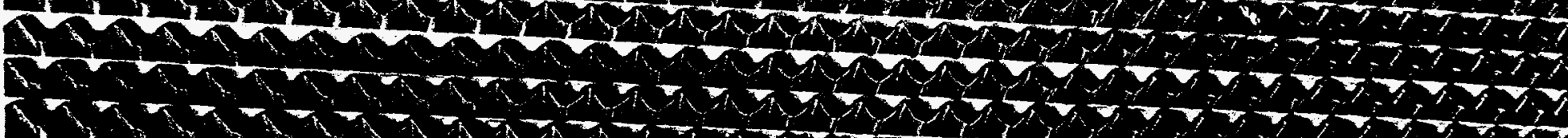

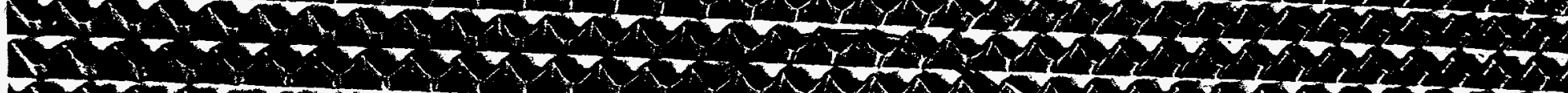

17 ,

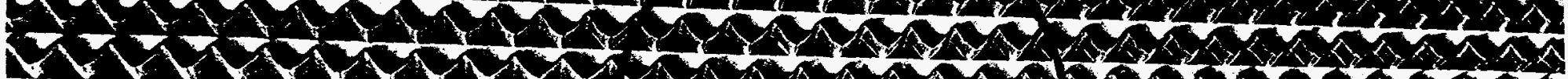

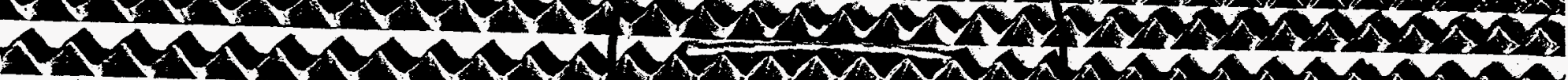
14. W,

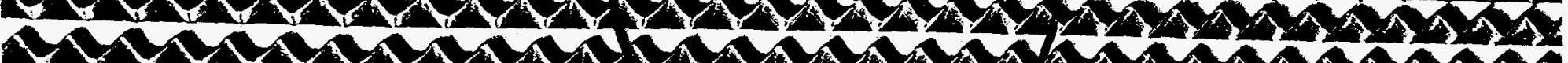

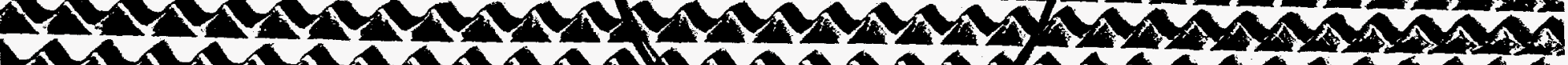

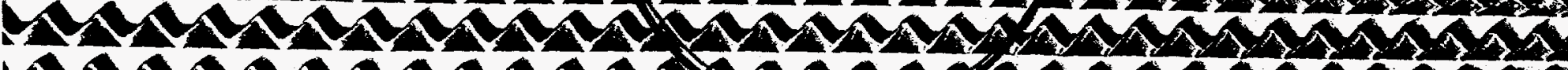

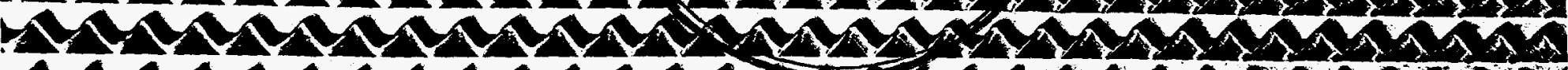

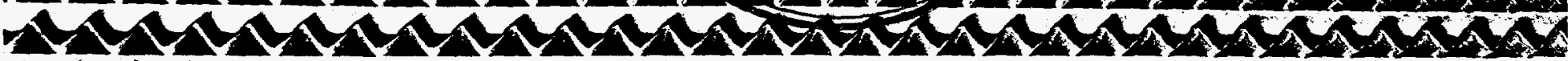

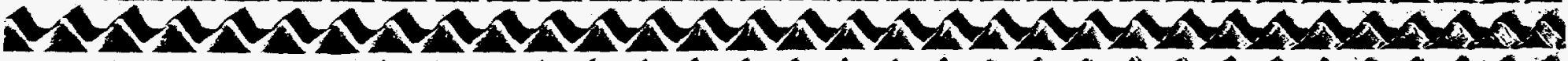

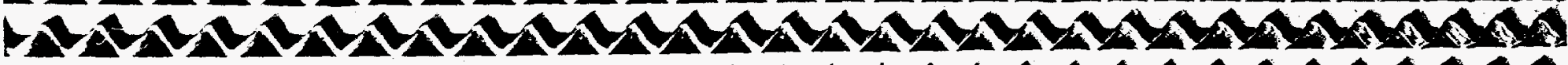

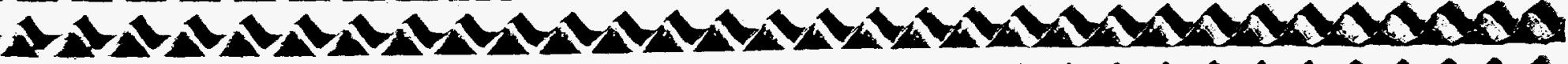

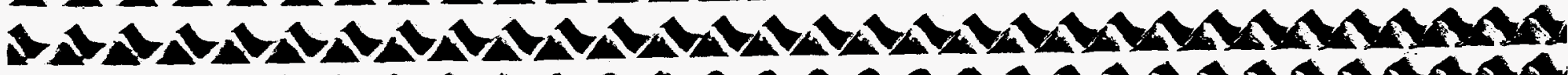

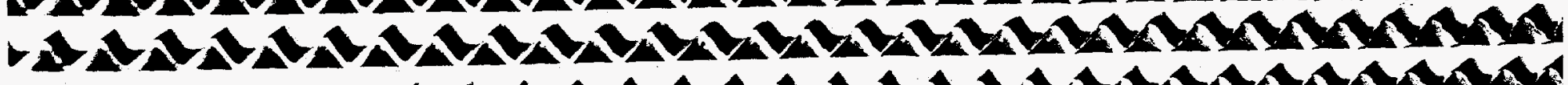

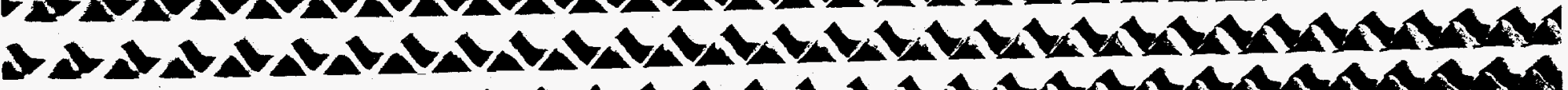

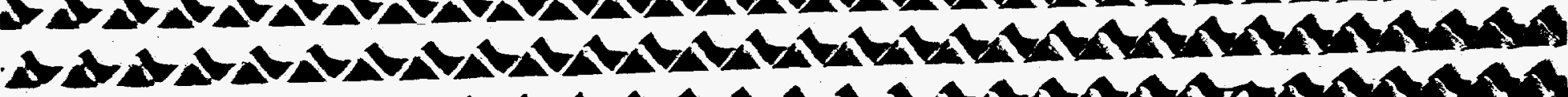

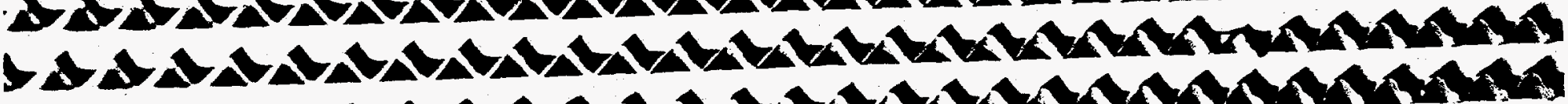

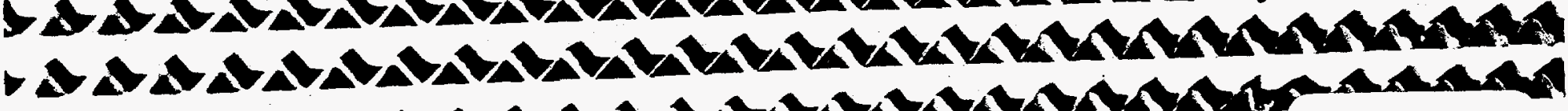

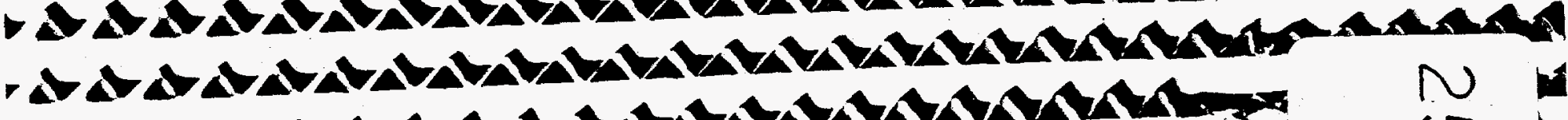

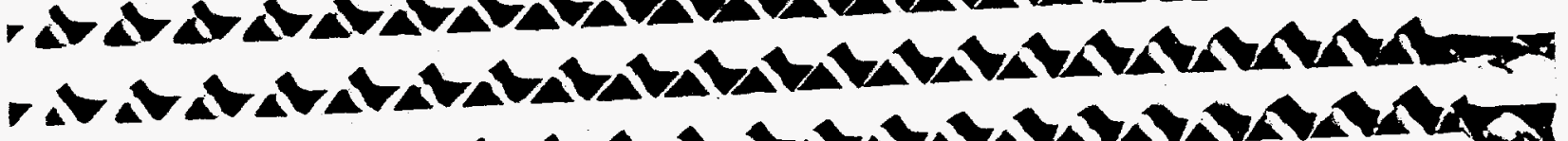

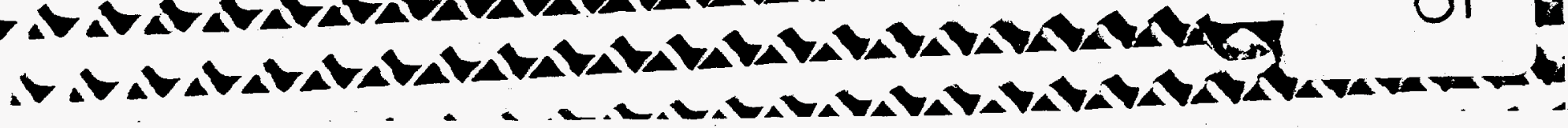





\section{APPENDIX 8}

Test Equipment Specifications

1) Tensile Tester - Instron Universal Testing Instrument Model TM-L

Used in Building 442

2) Tensile Tester - Monitor/Tensile $100 \mathrm{TM}$

Used in Building 707

3) Sample Cutter - Precision Adjustable Cutter (TMI 22-02-01)

Used in Building 442 and 750 Pad

4) Burst Tester - Mullen Burst Tester (Model C)

Used in Building 442 and Building 707

5) Micrometer - TMI 49-70 Automatic

Used in Building 442

6) Micrometer TMI 549M Automatic

Used in Building 707

7) Pressure Test Unit

Used in Building 442 


\section{Monitor/Tensile $100^{\mathrm{TM}} \&$ Monitor/Tensile $200^{\mathrm{TM}}$}

TMI 84-21-01 and TMI 84-21-02

\section{Features}

A component of TMI's Monitor X'M line for laboratory automation, including the following features: Digital display of tensile strength, elongation and T.E.A., storage and editing of up to 300 readings, selectable units (lbs., kg., N, in., and $\mathrm{mm}), \mathrm{RS}-232$, settable limits, statistics- average, standard deviation, high/low results, and report printout with optional printer

$\checkmark$ Range of 1-100 $\times .01$ lbs. load (TMI 84-21-01), or $20-200 \times .03$ lbs. load (TMI 84-21-02) $\left(0.0^{n}-8.000^{\text {" elongation })}\right.$

$\checkmark$ Settable parameters include: speed, width, length, preload, threshold, peak sensitivity, high and low limits, and units

$\checkmark$ Independently operated $1^{\text {n }}$ air grips with adjustable clamping pressure

$\checkmark$ Selectable speed of $.20-12.00 \times .01$ inches/minute

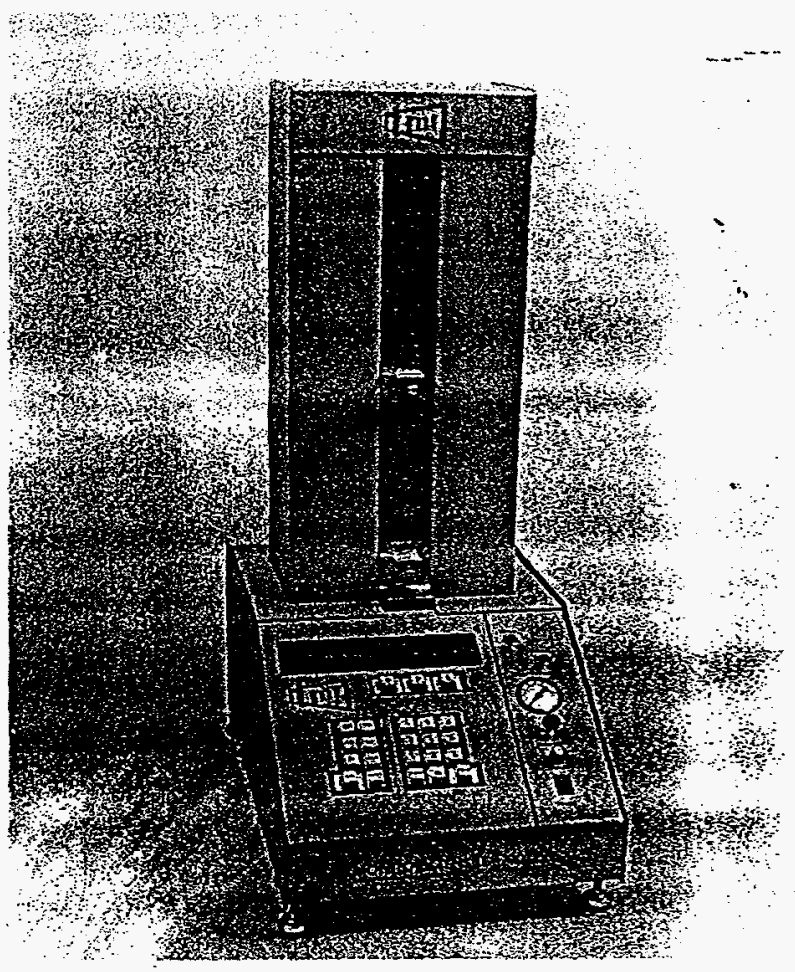

$\checkmark$ Jaws automatically return to selected position

$\checkmark$ Analog output of load and elongation for use with optional $X-Y$ recorder

$\checkmark$ Conforms to TAPPI T-494, ASTM D828, CPPA C.6H, ISO 1924-2.

\section{General Information}

Tensile testing is the most widely used method for indicating the serviceability of many papers. 'Tensile energy absorption (T.E.A.) indicates the durability of papers

Which are subjected to repetitive straining and stressing. The Monitor/Tensile $100^{\mathrm{TM}}$ (TMI 84-21-01) is a low capacity tensile tester designed for testing of paper and low elongation films and foils. The Monitor/ Tensile 200 TM (TMI 84-21-02) is designed specifically for paperboard.

Three factory preset test types include: machine direction, cross direction, and hand sheet terisile tests. Three additional test types are defined by the customer, and are changeable at any time.

TMl's Monitor $x^{\mathrm{TM}}$ line of testers offers increased versatility and capabilities for your. quality control and R\&D programs.

\section{Specifications}

Dimensions: $33 \mathrm{~cm} \times 48 \mathrm{~cm} \times 76 \mathrm{~cm}$ $13^{\prime \prime} \mathrm{W} \times 19^{n} \mathrm{D} \times 30^{\prime \prime} \mathrm{H}$

Electrical: $120 \mathrm{~V} / 60 \mathrm{~Hz} /$ single phase/8 amps (optional: $220 \mathrm{~V} / 50 \mathrm{~Hz} /$ single phase $/ 4$ amps)

Air requirements: $\min .420 \mathrm{kPa}(60 \mathrm{psi})$. Approximate weight: $18 \mathrm{~kg}$. (40 lbs.)

\section{Other Models Available}

Monitor/Tensile $100^{\mathrm{TM}}$ with $15 \mathrm{~mm}$ air grips (TMI 84-21-03)

Monitor/Tensile $25^{\mathrm{im}}-25 \mathrm{lb}$. maximum ; recommended for tissue (TMI 84-21-07)

\section{Options and Accessories}

Calibration fixture without weights

\section{(TMI 84-21-05)}

Four calibration weights and hanging device (TMI 84-21-06)

80-character printer with graphics (TMI 0.5-ก5-n1) 


\section{Cutters For Paper}

TMI 22-02-01, TMI 22-31-01, TMI 22-34-01, and TMI 22-35-01

\section{Features}

$\checkmark$ A wide line of cutters to áccomodate all your samplomeparatcricquirements

$\checkmark$ Precison Adjustable Strip Cutter (pictured) (TMI 22-02-01 and TMI 22-02-02) assures edges are parallel to .002". Prepares strips of $15 \mathrm{~mm}, 63 \mathrm{~mm}, .5^{\prime \prime}, 1^{\prime \prime}$, and 1.5"

$\checkmark$ All Purpose Guillotine-type Cutter. (TMI 22-31-01and TMI 22-31-02) assures clean, accurate cuts. Tabletop sizes: $40 \mathrm{~cm} \times 33 \mathrm{~cm}$, or $50 \mathrm{~cm} \times 39 \mathrm{~cm}$

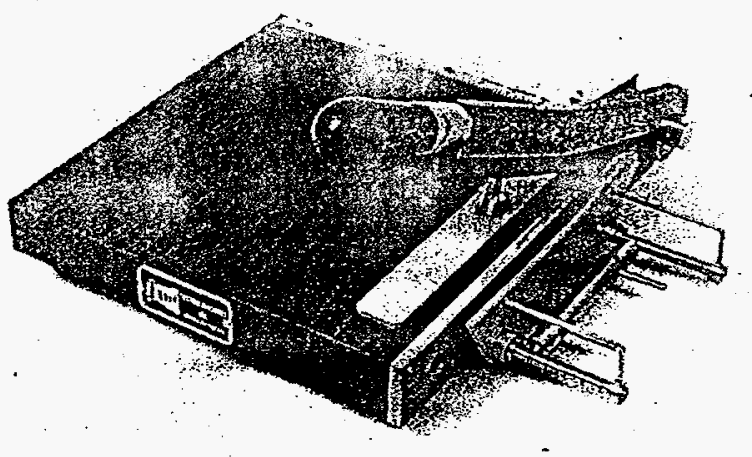

$\checkmark$ Twin Blade Cutter (pictured) (TMI 22-34-01) assures that samples are proper width and are parallel to .001". Available for samples of $15 \mathrm{~mm}, 25 \mathrm{~mm}, 63 \mathrm{~mm}, 0.5^{n}, 1^{\prime \prime}$, and $2^{n}$

$\checkmark$ Rotary Sample Cutters in Motorized (22-35-01) and Manual (22-35-02), cut 1" wide strips, up to 10 samples at a time

Specifications

Precision Adjustable Cutter (TMI 22-02-01):

Dimensions: $40.6 \mathrm{~cm} \times 38 \mathrm{~cm} \times 10 \mathrm{~cm}$ $16^{\prime \prime} \mathrm{W} \times 15^{\prime \prime} \mathrm{D} \times 4^{\prime \prime} \mathrm{H}$

Approximate weight: $11 \mathrm{~kg} .(24 \mathrm{lbs}$. 


\section{Mullen ${ }^{\circledR}$ Burst Testers}

TMI 13-01-00 (A), TMI 13-02-00 (C), TMI 13-05-00 (A-H), TMI 13-08-00 (C-A)

\begin{tabular}{|c|c|c|}
\hline Standard & Description & Tester \\
\hline ASTM D-774 & Bursting strength of paper & $C-A, A$ \\
\hline ASTM D-2529 & Bursting strength of paperboard \& linerboard & $\mathrm{A}-\mathrm{H}, \mathrm{A}$ \\
\hline ASTM D-2738 & $\begin{array}{l}\text { Bursting strength of corrugated \& solid } \\
\text { fiberboard }\end{array}$ & A-H, A \\
\hline ASTM D-751 & $\begin{array}{l}\text { Standard methods of testing coated fabrics: } \\
\text { "bursting strength" }\end{array}$ & $C-A, C$ \\
\hline $\begin{array}{l}\text { ANSI/ASTM } \\
\text { D-202 }\end{array}$ & $\begin{array}{l}\text { Bursting sfrength of untreated paper used for } \\
\text { electrical insulation: "Procedure A (for papers } \\
\text { bursting up to } 200 \text { psi } 1.4 \mathrm{Mpa} \text { ). } \\
\text { "Procedure } \mathrm{B}^{\text {" }} \\
\text { (for papers bursting at more than } 200 \mathrm{psi} \text { ) }\end{array}$ & A-A, C \\
\hline $\begin{array}{l}\text { ANSI/ASTM } \\
\text { D-3656 }\end{array}$ & $\begin{array}{l}\text { Bursting strength of insect screening and } \\
\text { louver cloth woven from vinyl-coated-glass } \\
\text { fiber yarn }\end{array}$ & $A-H, A$ \\
\hline ASTM D-3655 & $\begin{array}{l}\text { Bursting strength of men's and women's silver } \\
\text { knitted overcoat and jacket fabrics }\end{array}$ & to be \\
\hline ASTMD-3662 & Bursting strength of pressure-sensitive tapes & $\mathrm{A}-\mathrm{H}_{\mathrm{i}} \mathrm{A}$ \\
\hline ASTM D-3786 & $\begin{array}{l}\text { Hydraulic bursting strength of knitted goods \& } \\
\text { nonwoven fabrics-diaphragm bursting } \\
\text { strength }\end{array}$ & $C-A, C$ \\
\hline TAPPIT-403 & Bursting strength of paper & C-A, C \\
\hline TAPPI T-807 & Bursting strength of paperboard and linerboard & $\mathrm{A}-\mathrm{H}, \mathrm{A}$ \\
\hline TAPPIT-810 & $\begin{array}{l}\text { Bursting strength of corrugated and solid } \\
\text { fiberboard }\end{array}$ & $\mathrm{A}-\mathrm{H}, \mathrm{A}$ \\
\hline TAPPI ym 401 & Wet strength of paper (Mullen tester) & $\mathrm{C}-\mathrm{A}, \mathrm{C}$ \\
\hline TAPPI um 467 & Sizing of paperboard (loss of bursting strength) & $\mathrm{C}-\mathrm{A}, \mathrm{C}$ \\
\hline $\begin{array}{l}\text { Federal Test } \\
\text { Method \#191, } \\
\text { Method } 5122 \\
\end{array}$ & Bursting strength of cloth & $C-A, C$ \\
\hline ISO 2759 & Board- - determination of bursting strength & A-H, A \\
\hline ISO 2758 & Paper-determination of bursting strength & $C-A, C$ \\
\hline
\end{tabular}

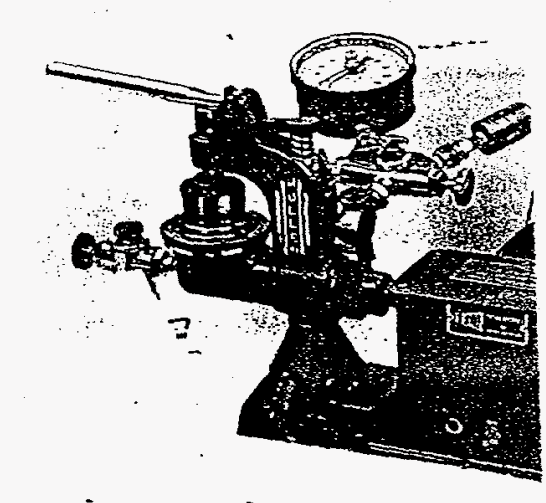

General Information

Mullen ${ }^{\circledR}$ Testers have been the standard for measuring bursting strength of paper, board, and textiles for many years. The automatic models of today, with their host of accessories, provide the kind of fine-tuned testing results that today's industry requires.

\section{Specifications}

Electrical: $120 \mathrm{~V} / 60 \mathrm{~Hz} /$ single phase/1 amp (optional: 220 V/50Hz/single phase/1 amp) TMI 13-01-00 (Model A):

Dimensions: $72 \mathrm{~cm} \times 85 \mathrm{~cm} \times 81 \mathrm{~cm}$ 28.5" W $\times 33.5^{\prime \prime} \mathrm{D} \times 32^{\prime \prime} \mathrm{H}$

Approximate weight: $45 \mathrm{~kg}$. (100 lbs.)

TMI 13-02-00 (Model C):

Dimensions: $65 \mathrm{~cm} \times 71 \mathrm{~cm} \times 71 \mathrm{~cm}$

$25.5^{\prime \prime} \mathrm{W} \times 28$ " D $\times 28^{\prime \prime} \mathrm{H}$

Approximate weight: $27 \mathrm{~kg} .(60 \mathrm{lbs}$.
TMI 13-05-00 (Model A-H):

Dimensions: $72 \mathrm{~cm} \times 85 \mathrm{~cm} \times 81 \mathrm{~cm}$

$28.5^{\prime \prime} \mathrm{W} \times 33.5^{\prime \prime} \mathrm{D} \times 32^{\prime \prime} \mathrm{H}$

Approximate weight: $68 \mathrm{~kg}$. (150 lbs.)

TMI 13-08-00 (Model C-A):

Dimensions: $72 \mathrm{~cm} \times 85 \mathrm{~cm} \times 81 \mathrm{~cm}$

28.5" W X 33.5" D x 32" H

Approximate weight: $39 \mathrm{~kg}$. (85 lbs.)

Air requirements: $552 \mathrm{kPa}(80 \mathrm{psi})$

Additional models available for Mullen burst tests and hydrostatic tests.

Mullen ${ }^{\circledR}$ is a registered trademark of B.F. Perkins. 


\section{9-70 and 49-72 Series Micrometers}

TMI 49-70-01 and TMI 49-72-01

$\checkmark$ Measures the thickness of most materials, including paper, fiberboard, corrugated and container board, plastic films, foils, etc.

$\checkmark$ Digital display

$\checkmark$ Dual range (English or Metric)

$\checkmark$ Range of measurement: Model 49-70:

English - $0.0-0.050 " \times 0.0001 "$ ", Metric- $0.0-1.270 \mathrm{~mm} \times 0.003 \mathrm{~mm}$

$\checkmark$ Range of measurement: Model 49-72: English-0.5 x.001", Metric- $12.70 \mathrm{~mm} \times .03 \mathrm{~mm}$

$\checkmark$ Superior mechanical design

$\checkmark$ Compact, for use throughout the laboratory and production floor

$\checkmark$ Motorized automatic cycling

$\checkmark$ 5-second test cycle

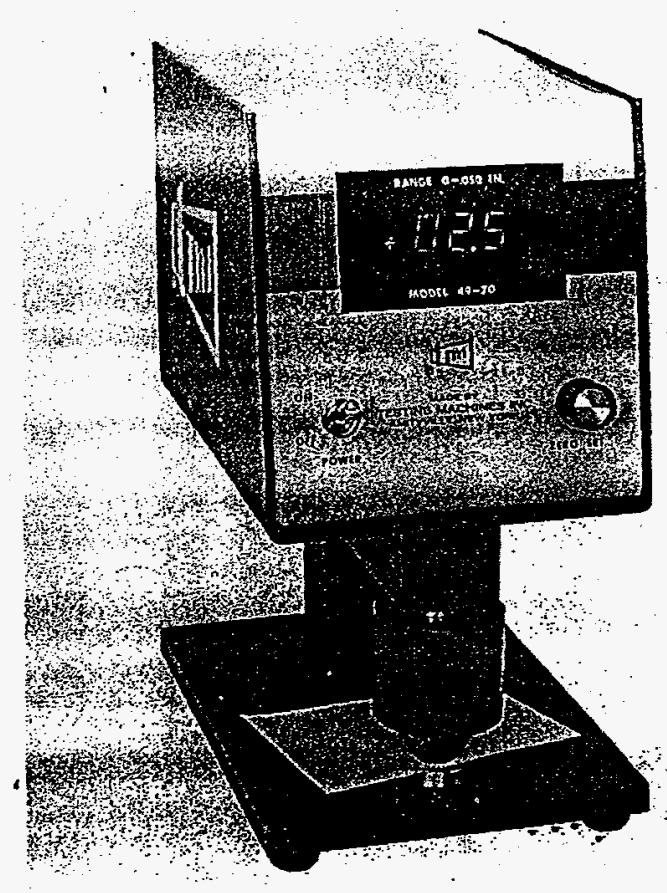

$\checkmark$ Standard anvil diameter16.00 mm (.63"), Load: $50.37 \mathrm{kPa}$ (7.3 psi)

$\checkmark$ Special anvil diameters and dead weight loads available upon request

$\checkmark$ Model 49-70 conforms to TAPPI T-411 and ASTM D374

\section{General Information}

TMI 49-70 Series Micrometers provide the precision necessary for the critical thickness measurement of films, foils, tissue, and a wide variety of papers and other materials within the range specified above.

TMI 49-72 Series Micrometers accurately measure the thickness of corrugated and paper board, paper, plastics, felt, rubber, and other sheet materials within the range specified above.

\section{Specifications.}

Dimensions: $15 \mathrm{~cm} \times 20 \mathrm{~cm} \times 29 \mathrm{~cm}$ 6" W $\times 8^{\mathrm{N}} \mathrm{D} \times 11.5^{\mathrm{\prime}} \mathrm{H}$

Electrical: $120 \mathrm{~V} / 60 \mathrm{~Hz} /$ single phase/1 amp (optional: $220 \mathrm{~V} / 50 \mathrm{~Hz} /$ single phase/1 amp) Approximate weight: $9 \mathrm{~kg}$. (20.5 lbs.)

\section{Other Models Available}

Digital Micrometer; .25" (6.35 mm) anvil; 25 psi (172 kPa), 0 - .05" x.0001" (0 - $1.27 \mathrm{~mm} \times 0.003 \mathrm{~mm}$ ) (TMI 49-70-02) Digital Micrometer; 2 " anvil $(50.80 \mathrm{~mm})$, $95 \mathrm{~g} / \mathrm{in}^{2}(1.44 \mathrm{kPa}), 0-.05^{\prime \prime}(0-1.27 \mathrm{~mm})$ (TMl 49-70-03)

\section{Options and Accessories}

Set of 5 gauge blocks; .010" - .050" $\mathrm{x}$ $.000001 "$ for model 49-70 (TMI 35-12-02).

Set of 6 gauge block for $1 / 2^{\prime \prime}$ mics; $.01 "-.5^{\prime \prime} \times .0001^{\prime \prime}$ (TMI 35-12-03)

Set of 5 gauge blocks for $2^{\prime \prime}$ anvils (TMI 35-12-05)

See page 9 for TMl's 49-60 Micrometers 


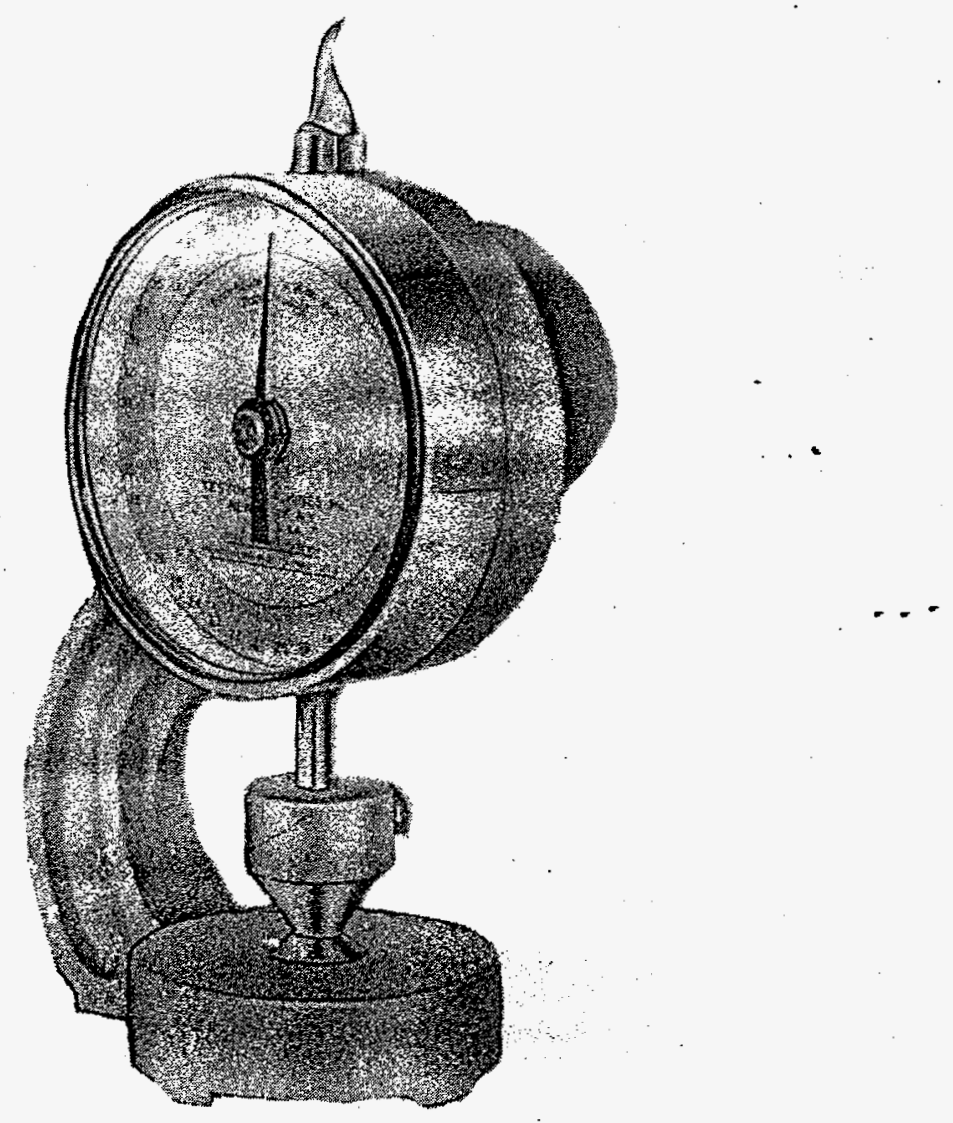

T.M. I. AUTOMATIC MICROMETER MODEL NO. 549M 


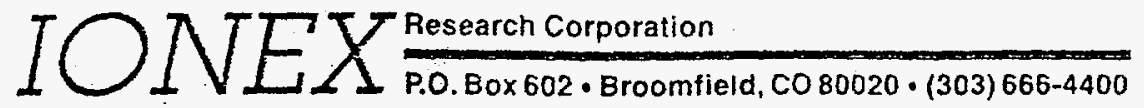

March 13, 1995

As you requested, we have evaluated the possibility of adapting one of our portable HEPA filter units for use as a HEPA Test Module in which HEPA filter elements could be subjected to - excessive dust, water, and pressure loading to the point of media failure. The attached sketch, D6612, indicates our proposed system. We have designed a conventional side-loaded HEPA retaining module into a stainless steel housing with the following accessory items:

1. DOP injection manifold used in possible HEPA testing of the contained HEPA element.

2. Water spray header for possible injection of water to the upstream face of the HEPA element. (Drain connections will also be provided.)

3. DOP sample port upstream of the HEPA element and downstream of the fan.

4. Two viewing windows for visual investigation of the downstream face of the HEPA element.

5. Metal panel filter installed to protect against the discharge of particulate matter or debris from the tested HEPA element.

6. System fan capable of developing a total static pressure of up to $18^{\prime \prime}$ W.G. (1000 CFM).

7. Outlet duct with removable diffuser for air discharge into the operating space.

8. Flow element capable of providing a velocity pressure directly relatable to system flow. (Output could be routed to customer's flow indicator or transmitter.) Flow element will be installed at the inlet of the fan.

9. Differential pressure indicating transmitter (Dwyer Series 605) with range of 0-20" W.G. to provide measurement of differential pressure across the HEPA element. (Output could be routed to customer's strip chart recorder.) 


\section{APPENDIX 8}

Test Equipment Specifications

1) Tensile Tester - Instron Universal Testing Instrument Model TM-L Used in Building 442

2) Tensile Tester - Monitor/Tensile 100 TM

Used in Building 707

3) Sample Cutter - Precision Adjustable Cutter (TMI 22-02-01)

Used in Building 442 and 750 Pad

4) Burst Tester - Mullen Burst Tester (Model C)

Used in Building 442 and Building 707

5) Micrometer - TMI 49-70 Automatic

Used in Building 442

6) Micrometer TMI 549M Automatic

Used in Building 707

7) Pressure Test Unit

Used in Building 442 


\section{Instron Universal Testing Instruments}

\author{
BASIC SPECIFICATIONS \\ TABLE MODEL \\ Model TM, Standard Speed \\ Model TM-L, Slow Speed
}

Table Models:
TM \& TM-L

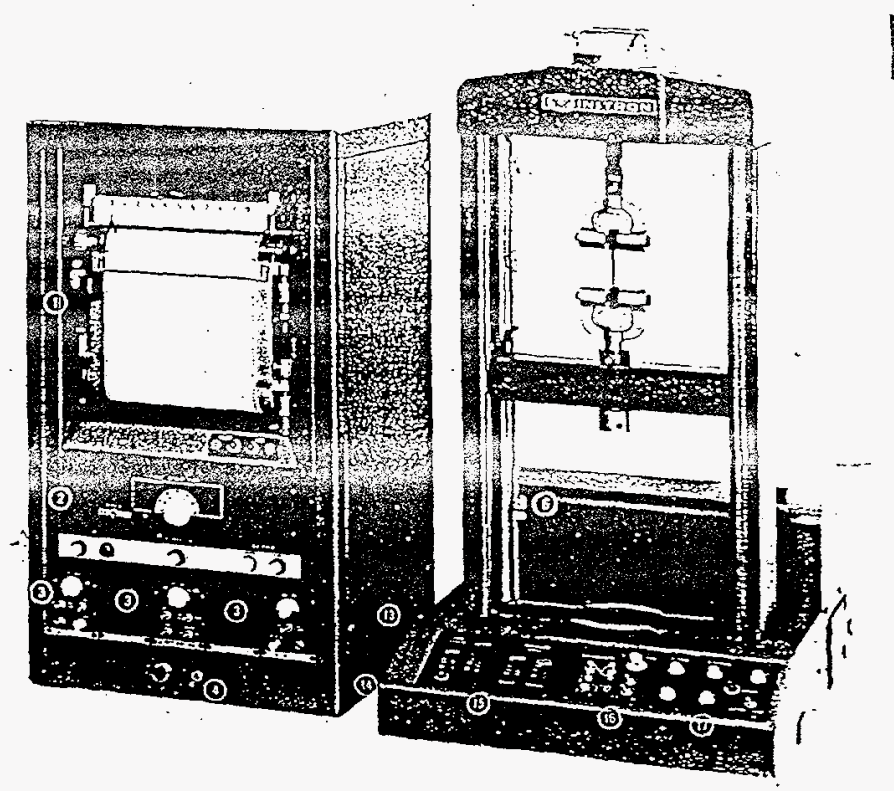

TENSION Load Ranges, Full Scale, Nominal

(Each group of ranges provided by single interchangeable cells, ordered individually)

Tension Cell A: 10,20, 50, 100, 200, 500 grams

( 2 grams ultra-sensitive range)

Tension Cell B: $100,200,500,1000,2000$ grams (20 grams ultra-sensitive range).

Tension Cell CT: 5, 10, 20, 50, 100, 200 pounds (1 pound ultra-sensitive range)

Additional tension cells that may be used, although not normally ordered with the Table Model.

Tension Cell C: $1,2,5,10,20,50$ pounds (0.2 pounds ultra-sensitive rangel

Tention Cell CM: 1, 2, 5, 10, 20, 50 kilograms (0.2 kilogram ultra-sensitive range)

\section{COMPRESSION Load Ranges, Full Scale; Nominal}

Compression Cell CB: $\quad 100,200,500,1000,2000$ grams (20 grams ultra-sensitive range)

Compression Cell CCT: 5, 10, 20, 50, 100, 200 pounds (1 pound ultra-sensitive range)

Additional compression cells that may be used, although not nor malfyordexed with the Table Model.

\section{Compression Cell CC: $\quad 1,2,5,10,20,50$ pounds \\ (0. 2 pounds ultra-sensitive range)}

Compression Cell CCM: 1, 2, 5, 10, 20, 50 kilograms (0.2 kilogram ultra-gensitive range)

Range of Crosshead Speeds:

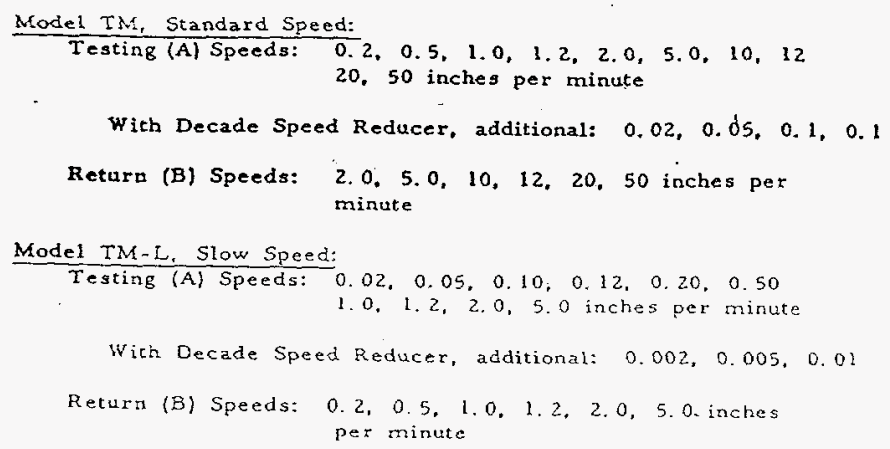

\section{Range of Chart Speeds:}

$0.2,0.5,1.0,1.2,2.0,5.0,10,12,20,50$ inches per minu

NOTE: Additional crosshead and chart speeds are avallable through special change gears.

\section{Crosshead Travel:}

Maximum travel 33 inches, standard. Actual travel, less, depe: on sixe of gripa, fixtures, and samples.

Increased crosshead travel available on special order.

\section{Standard Recorder Syatem:}

Potentiometer-type strip chart. Ball-point pen writing system Load Weighing Accuracy: $\pm 1 / 2 \%$ of indicated load, or $\pm 1 / 4$ of recorder scale in ase, whichever is greater, for all load ranges.

Powar Requirements:

115 volts, 60 cycles, A. C. . standard

Also adapter for 50 cycle and 100 volts or 220 rolts on special order.

Normal Consumption 1800 V. A

Space Between Drive Screws:

15 inches horizontal

Overall Dimensions:

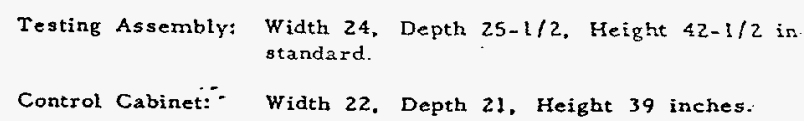

Weight, Approximate:

$$
\text { Testing Assembly: } 150 \text { pounds }
$$$$
\text { Control Cabinet: } 150 \text { pounds }
$$ 


\section{Monitor/Tensile $100^{\mathrm{TM}} \&$ Monitor/Tensile $200^{\mathrm{TM}}$}

TMI 84-21-01 and TMI 84-21-02

\section{Features}

A component of TMl's Monitor X'M line for laboratory automation, including the following features: Digital display of tensile strength, elongation and T.E.A., storage and editing of up to 300 readings, selectable units (lbs., $\mathrm{kg}$., $\mathrm{N}$, in., and $\mathrm{mm}$ ), RS-232, settable limits, statistics- average, standard deviation, high/low results, and report printout with optional printer

$\checkmark$ Range of $1-100 \times .01 \mathrm{lbs}$. load (TMI 84-21-01), or 20-200 $\times .03$ lbs: load (TMI 84-21-02) (0.0" - 8.000" elongation)

$\checkmark$ Settable parameters include: speed, width, length, preload, threshold, peak sensitivity, high and low limits, and units

$\checkmark$ Independently operated 1" air grips with adjustable clamping pressure

$\checkmark$ Selectable speed of $.20-12.00 \times .01$ inches/minute

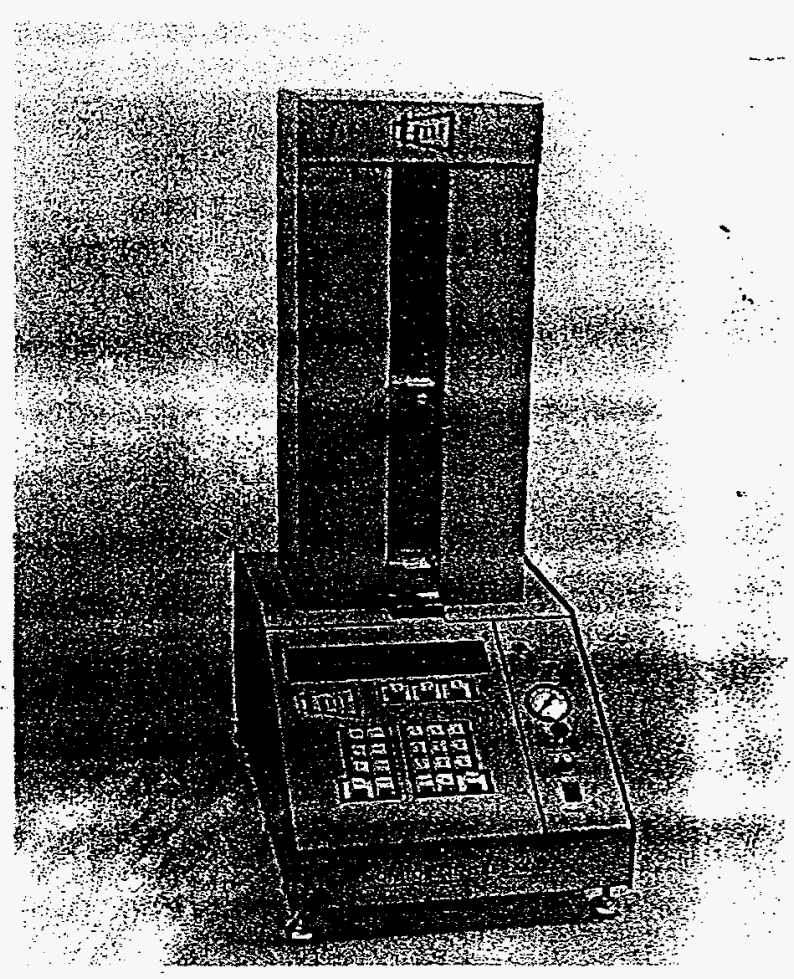

$\checkmark$ Jaws automatically return to selected position

$\checkmark$ Analog output of load and elongation for use with optional $X-Y$ recorder

$\checkmark$ Conforms to TAPPIT-494, ASTM D828, CPPA C.6H, ISO $1924-2$

\section{General Information}

Tensile testing is the most widely used method for indicating the serviceability of many papers. Tensile energy absorption (T.E.A.) indicates the durability of papers which are subjected to repetitive straining and stressing. The Monitor/Tensile $100^{\mathrm{Tm}}$ (TMI 84-21-01) is a low capacity tensile tester designed for testing of paper and low elongation films and foils. The Monitor/ Tensile $200^{\mathrm{TM}}$ (TMI 84-21-02) is designed specifically for paperboard.

Three factory preset test types include: machine direction, cross direction, and hand sheet terisile tests. Three additional test types are defined by the customer, and are changeable at any time.

TMl's Monitor $x^{\text {TM }}$ line of testers offers increased versatility and capabilities for your quality control and $R \& D$ programs.

\section{Specifications}

Dimensions: $33 \mathrm{~cm} \times 48 \mathrm{~cm} \times 76 \mathrm{~cm}$ $13^{\prime \prime} \mathrm{W} \times 19^{n} \mathrm{D} \times 30^{\prime \prime} \mathrm{H}$

Electrical: $120 \mathrm{~V} / 60 \mathrm{~Hz} /$ single phase $/ 8$ amps (optional: $220 \mathrm{~V} / 50 \mathrm{~Hz} /$ single phase/4 amps)

Air requirements: $\min .420 \mathrm{kPa}$ (60 psi) Approximate weight: $18 \mathrm{~kg}$. (40 lbs.)

\section{Other Models Available}

Monitor/Tensile $100^{\mathrm{rm}}$ with $15 \mathrm{~mm}$ air grips (TMI 84-21-03)

Monitor $/$ Tensile $25^{\mathrm{TM}}-25 \mathrm{lb}$. maximum ; recommended for tissue (TMI 84-21-07)

\section{Options and Accessories}

Calibration fixture without weights

(TMI 84-21-05)

Four calibration weights and hanging device

(TMI 84-21-06)

80-character printer with graphics (TMI 0.5-ก5-01) 


\section{Cutters For Paper}

TMI 22-02-01, TMI 22-31-01, TMI 22-34-01, and TMI 22-35-01

\section{Features}

$\checkmark$ A wide line of cutters to accomodate all your sample preparation requirements

$\checkmark$ Precison Adjustable Strip Cutter (pictured) (TMI 22-02-01 and TMI 22-02-02) assures edges are parallel to .002". Prepares strips of $15 \mathrm{~mm}, 63 \mathrm{~mm}, 5^{\prime \prime}, 1^{\prime \prime}$, and 1.5"

$\checkmark$ All Purpose Guillotine-type Cutter (TMI 22-31-01and TMI 22-31-02) assures clean, accurate cuts. Tabletop sizes: $40 \mathrm{~cm} \times 33 \mathrm{~cm}$, or $50 \mathrm{~cm} \times 39 \mathrm{~cm}$

$\checkmark$ Twin Blade Cutter (pictured) (TMI 22-34-01) assures that samples are proper width and are parallel to $.001^{\prime \prime}$. Available for samples of $15 \mathrm{~mm}, 25 \mathrm{~mm}, 63 \mathrm{~mm}, 0.5^{n}, 1^{n}$, and $2^{\prime \prime}$

$\checkmark$ Rotary Sample Cutters in Motorized (22-35-01) and Manual (22-35-02), cut 1" wide strips, up to 10 samples at a time

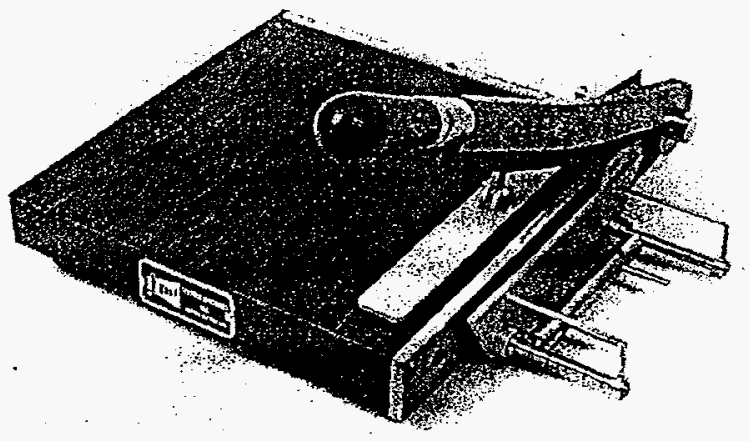

\section{Specifications}

Precision Adjustable Cutter (TMI 22-02-01):

Dimensions: $40.6 \mathrm{~cm} \times 38 \mathrm{~cm} \times 10 \mathrm{~cm}$ $16 " \mathrm{~W} \times 15^{\prime \prime} \mathrm{D} \times 4$ " H

Approximate weight: $11 \mathrm{~kg}$. (24 lbs.) 


\section{Mullen ${ }^{\circledR}$ Burst Testers}

TMI 13-01-00 (A), TMI 13-02-00 (C), TMI 13-05-00 (A-H), TMI 13-08-00 (C-A)

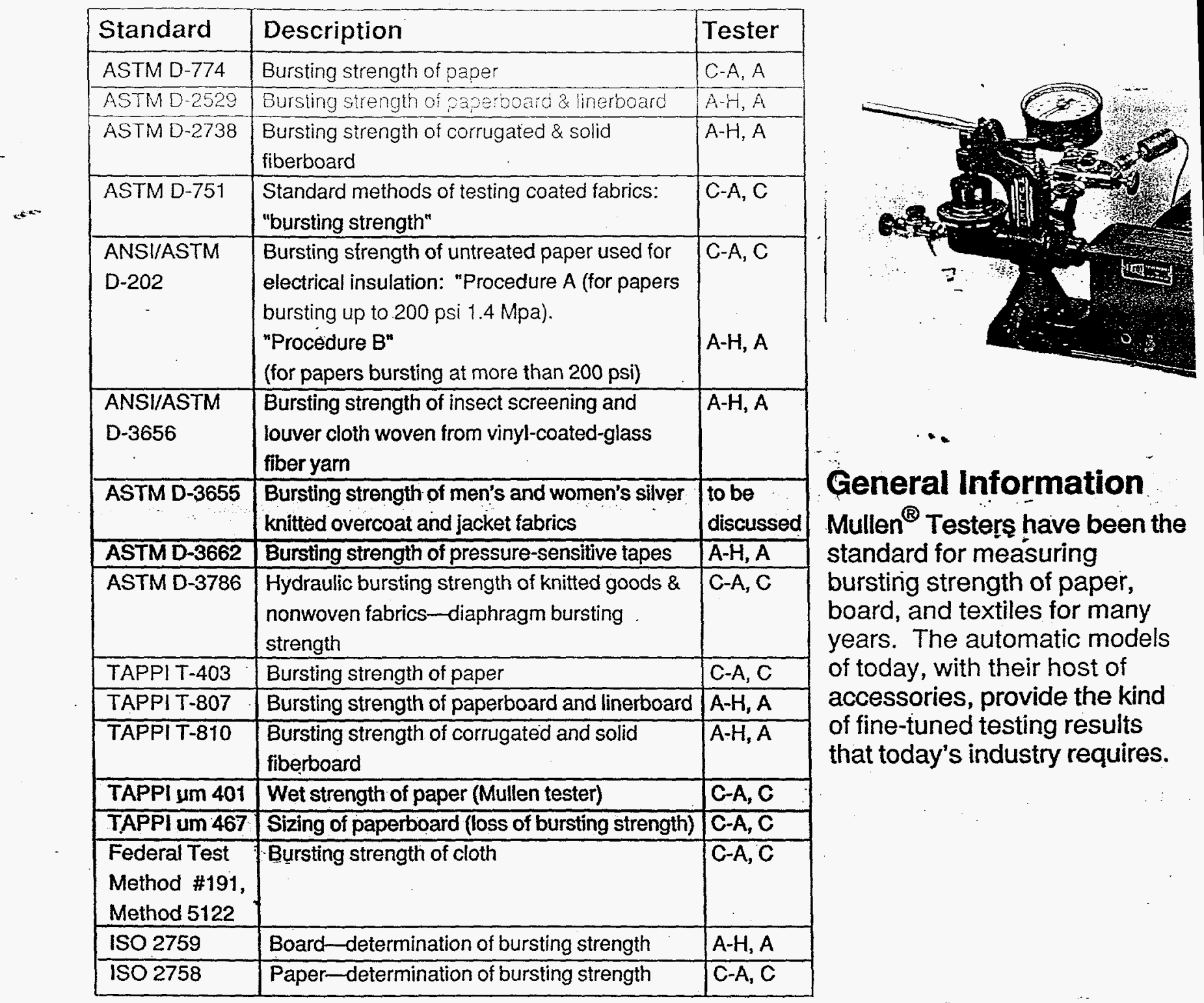

\section{Specifications}

Electrical: $120 \mathrm{~V} / 60 \mathrm{~Hz} /$ single phase/1 amp (optional: $220 \mathrm{~V} / 50 \mathrm{~Hz} /$ single phase $/ 1 \mathrm{amp}$ )

TMI 13-01-00 (Model A):

Dimensions: $72 \mathrm{~cm} \times 85 \mathrm{~cm} \times 81 \mathrm{~cm}$

28.5" W $\times 33.5^{\prime \prime} \mathrm{D} \times 32$ " H

Approximate weight: $45 \mathrm{~kg}$. (100 lbs.)

TMI 13-02-00 (Model C):

Dimensions: $65 \mathrm{~cm} \times 71 \mathrm{~cm} \times 71 \mathrm{~cm}$

25.5" W $\times 28^{\prime \prime} \mathrm{D} \times 28^{\prime \prime} \mathrm{H}$

Approximate weight: $27 \mathrm{~kg}$. (60 lbs.)
TMI 13-05-00 (Model A-H):

Dimensions: $72 \mathrm{~cm} \times 85 \mathrm{~cm} \times 81 \mathrm{~cm}$

28.5" W $\times 33.5^{\prime \prime} \mathrm{D} \times 32$ " $\mathrm{H}$

Approximate weight: $68 \mathrm{~kg}$. (150 lbs.)

TMI 13-08-00 (Model C-A):

Dimensions: $72 \mathrm{~cm} \times 85 \mathrm{~cm} \times 81 \mathrm{~cm}$

28.5" W $\times 33$. 3" D $^{\prime}$ 32" H

Approximate weight: $39 \mathrm{~kg}$. (85 lbs.)

Air requirements: $552 \mathrm{kPa}$ (80 psi)

Additional models available for Mullen burst tests and hydrostatic tests.

Mullen ${ }^{\circledR}$ is a registered trademark of B.F. Perkins. 


\section{9-70 and 49-72 Series Micrometers}

TMI 49-70-01 and TMI 49-72-01

$\checkmark$ Measures the thickness of most materials, including paper, fiberboard, corrugated and container board, plastic films, foils, etc.

$\checkmark$ Digital display

$\checkmark$ Dual range (English or Metric)

$\checkmark$ Range of measurement: Model 49-70:

- English - 0.0-0.050" $\times 0.0001 "$ ", Metric- $0.0-1.270 \mathrm{~mm} \times 0.003 \mathrm{~mm}$

$\checkmark$ Range of measurement: Model 49-72: English-0.5 x.001", Metric- $12.70 \mathrm{~mm} \times .03 \mathrm{~mm}$

$\checkmark$ Superior mechanical design

$\checkmark$ Compact, for use throughout the laboratory and production floor

$\checkmark$ Motorized automatic cycling

$\checkmark$ 5-second test cycle

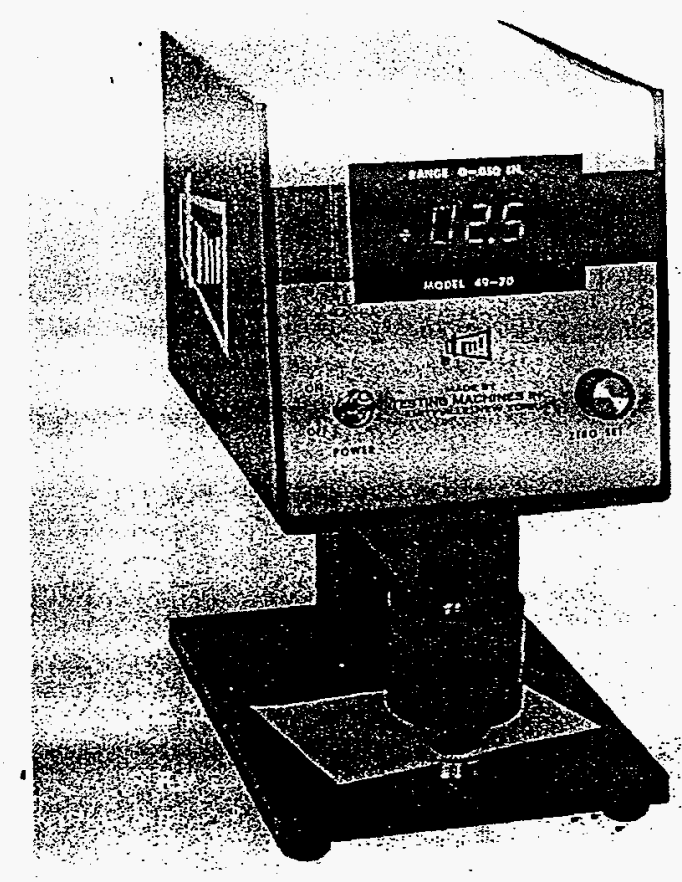

$\checkmark$ Standard anvil diameter16.00 mm (.63") , Load: $50.37 \mathrm{kPa}$ (7.3 psi)

$\checkmark$ Special anvil diameters and dead weight loads available upon request

$\checkmark$ Model 49-70 conforms to TAPPI T-411 and ASTM D374

\section{General Information}

TMI 49-70 Series Micrometers provide the precision necessary for the critical thickness measurement of films, foils, tissue, and a wide variety of papers and other materials within the range specified above.

TMI 49-72 Series Micrometers accurately measure the thickness of corrugated and paper board, paper, plastics, felt, rubber, and other sheet materials within the range specified above.

\section{Specifications}

Dimensions: $15 \mathrm{~cm} \times 20 \mathrm{~cm} \times 29 \mathrm{~cm}$ 6" W $\times 8$ " D $\times 11.5^{\prime \prime} \mathrm{H}$

Electrical: $120 \mathrm{~V} / 60 \mathrm{~Hz} /$ single phase $/ 1 \mathrm{amp}$ (optional: $220 \mathrm{~V} / 50 \mathrm{~Hz} /$ single phase/1 amp) Approximate weight: $9 \mathrm{~kg}$. (20.5 lbs.)

\section{Other Models Available}

Digital Micrometer; .25" (6.35 mm) anvil;

$25 \mathrm{psi}(172 \mathrm{kPa}), 0-.05^{\prime \prime} \times .0001 "$ (0-1.27 mm x 0.003 mm) (TMI 49-70-02) Digital Micrometer; $2 "$ anvil $(50.80 \mathrm{~mm})$, $95 \mathrm{~g} / \mathrm{in}^{2}(1.44 \mathrm{kPa}), 0$ - .05" (0 - $\left.1.27 \mathrm{~mm}\right)$ (TMI 49-70-03)

\section{Options and Accessories}

Set of 5 gauge blocks; .010" - .050" $x$ .000001" for model 49-70 (TMI 35-12-02)

Set of 6 gauge block for $1 / 2^{\prime \prime}$ mics; $.01 "$ - .5" x .0001" (TMI 35-12-03)

Set of 5 gauge blocks for 2 " anvils (TMI 35-12-05)

See page 9 for TMI's 49-60 Micrometers 
W6TS ON $7300 \mathrm{~W}$

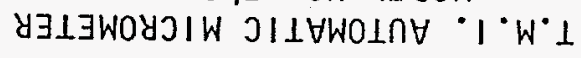

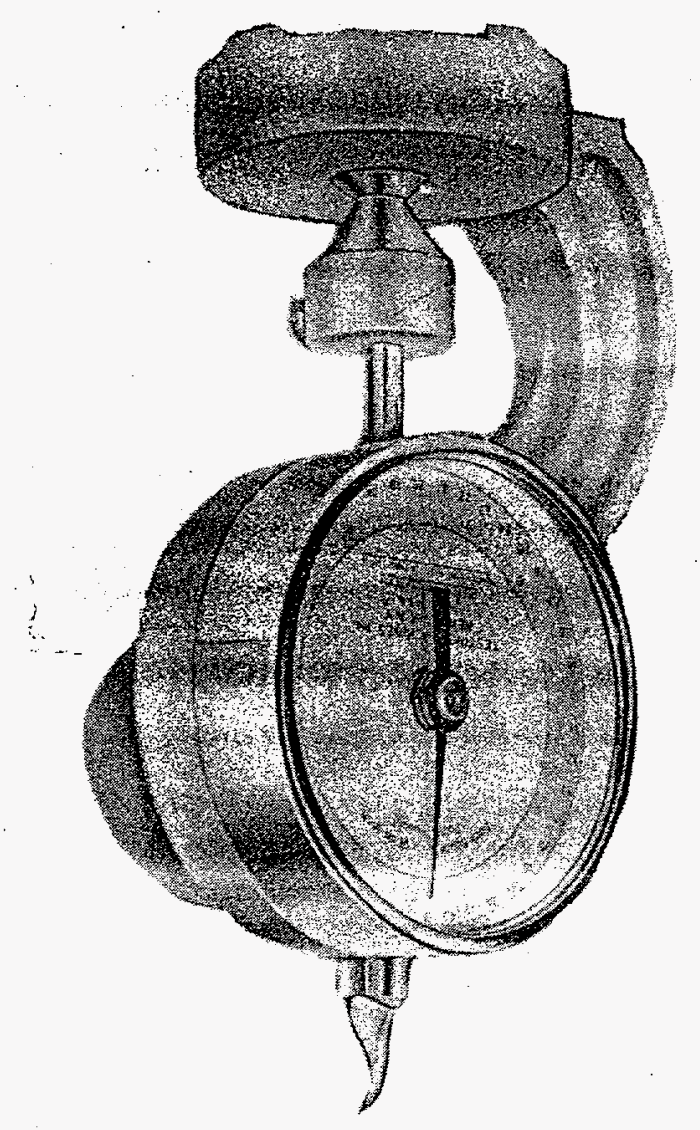


As you requested, we have evaluated the possibility of adapting one of our portable HEPA filter units for use as a HEPA Test Module in which HEPA filter elements could be subjected to excessive dust, water, and pressure loading to the point of media failure. The attached sketch, D6612, indicates our proposed system. We have designed a conventional side-loaded HEPA retaining module into a stainless steel housing with the following accessory items:

1. DOP injection manifold used in possible HEPA testing of the contained HEPA element.

2. Water spray header for possible injection of water to the upstream face of the HEPA element. (Drain connections will also be provided.)

3. DOP sample port upstream of the HEPA element and downstream of the fan.

4. Two viewing windows for visual investigation of the downstream face of the HEPA element.

5. Metal panel filter installed to protect against the discharge of particulate matter or debris from the tested HEPA element.

6. System fan capable of developing a total static pressure of up to $18^{\prime \prime}$ W.G. (1000 CFM).

7. Outlet duct with removable diffuser for air discharge into the operating space.

8. Flow element capable of providing a velocity pressure directly relatable to system flow. (Output could be routed to customer's flow indicator or transmitter.) Flow element will be installed at the inlet of the fan.

9. Differêntial pressure indicating transmitter (Dwyer Series 605) with range of 0-20" W.G. to provide measurement of differential pressure across the HEPA element. (Output could be routed to customer's strip chart recorder.) 